\title{
Women's job search behavior in the Egyptian labor market
}

Somaya Abdel Mowla

Follow this and additional works at: https://knowledgecommons.popcouncil.org/departments_sbsr-pgy

Part of the Demography, Population, and Ecology Commons, Family, Life Course, and Society Commons, International Public Health Commons, Labor Economics Commons, Women's Health Commons, and the Work, Economy and Organizations Commons How does access to this work benefit you? Let us know!

\section{Recommended Citation}

Abdel Mowla, Somaya. 2011. "Women's job search behavior in the Egyptian labor market," Gender and Work in the MENA Region Working Paper no. 21. Cairo: Population Council. 


\section{NUMBER 21}

JUNE 2011

GENDER AND WORK IN THE MENA REGION

WORKING PAPER SERIES

Poverty, Job Quality and Labor Market Dynamics

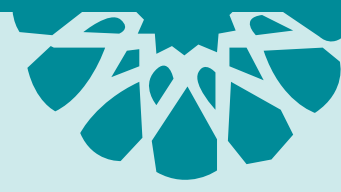

Women's Job Search Behavior in

the Egyptian Labor Market

Somaya Abdel Mowla

1 Population Council 
Somaya Abdel-Mowla is an Associate Professor of Economics, Faculty of Commerce and Business Administration, Helwan University, Cairo, Egypt. Email: somaya204@yahoo.com

The research presented in this publication is the result of a project funded by Canada's International Development Research Centre (www.idrc.ca).

\section{IDRC *RDI}

Canadä

\section{(1) Population Council}

Research that makes a difference

The Population Council confronts critical health and development issues-from stopping the spread of HIV to improving reproductive health and ensuring that young people lead full and productive lives. Through biomedical, social science and public health research in 50 countries, the Council works with our partners to deliver solutions that lead to more effective policies, programs, and technologies to improve lives worldwide. Established in 1952 and headquartered in New York, the Council is a nongovernmental, nonprofit organization with an international board of trustees.

Population Council

Egypt Office

59 Misr Helwan Agricultural Road, Maadi, Cairo, Egypt

Tel.: (+202) 2525-5965, (+202) 2525-5967, (+202) 2525-5968

Facsimile: $(+202)$ 2525-5962

Website: http://www.popcouncil.org

Email: pcouncil@popcouncil.org

(C) 2011 The Population Council, Inc.

Any part of this publication may be reproduced without permission for limited distribution, provided it is distributed without charge and the Population Council is acknowledged as its source. The Population Council would appreciate receiving a copy of any materials in which the text is used.

ISSN: 11878/2011 
NUMBER 21

JUNE 2011

GENDER AND WORK IN THE MENA REGION WORKING PAPER SERIES

Poverty, Job Quality and Labor Market Dynamics

\section{Women's Job Search Behavior in the Egyptian Labor Market}

Somaya Abdel Mowla 



\section{Table of contents}

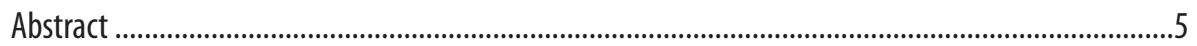

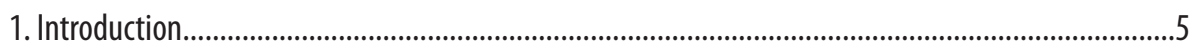

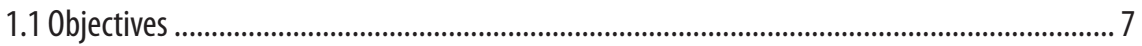

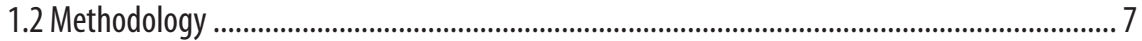

2. Theoretical Framework...............................................................................................................

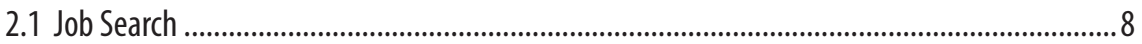

2.2 Job Search Behavior ..........................................................................................................

2.3 Job Search Behavior and Labor Market Outcomes ................................................................ 11

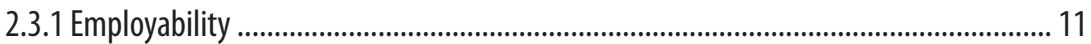

2.3.2 Job Quality .................................................................................................... 13

2.3.3 Returns ..........................................................................................................

2.4 Main Determinants of Job Search Behavior ..........................................................................15

2.4.1 Personal Characteristics ...............................................................................................

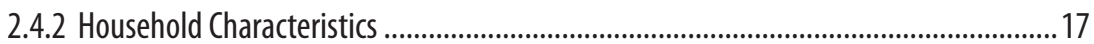

2.4.3 Labor market conditions ......................................................................................... 18

3. Job Search Behavior and the Gender Gap in the Labor Market ..................................................19

3.1 Gender Gap in the Labor Market ................................................................................19

3.2 Gender Gap in Job Search Behavior-Different Hypotheses .................................................19

3.2.1 Social Roles Hypotheses ......................................................................................... 20

3.2.2 Differences in Job Search Costs Hypotheses ........................................................... 20

3.2.3 Differences in Job Search Benefits Hypotheses ........................................................... 20

3.2.4 Differences in Personality Characteristics Hypotheses ................................................ 21

3.3 Gender Gap in Job Search Behavior-Empirical Evidence ..................................................... 21

3.3.1 Job Search Intensity ........................................................................................ 22

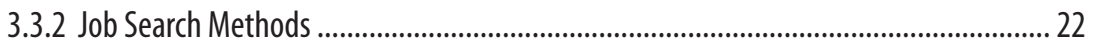

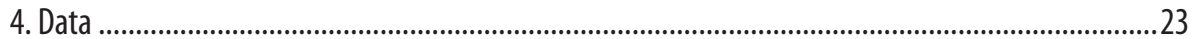

5. Job Search Behavior in Egypt (1998-2006)-A Gender Perspective ................................................ 23

5.1 Measures of Job Search Behavior .........................................................................................23

5.1.1 Job Search Propensity (11) ................................................................................. 24

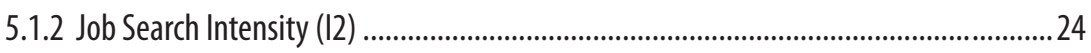

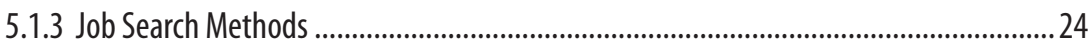

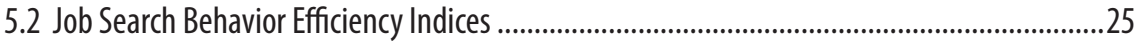

5.3 Job Search Propensity (1998-2006) .....................................................................................

5.4 Job Search Intensity (1998-2006) ......................................................................................2 


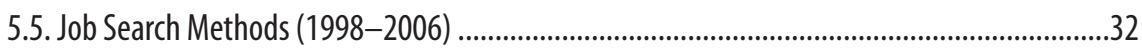

5.5.1 Patterns of job search and job finding ......................................................................

5.5.2 Formal job search ................................................................................................

5.5.3 Informal job search .............................................................................................. 39

5.5.4 The formal and informal job search ........................................................................

5.6 Job Search Efficiency Index 1 (JSE1) (1998-2006) .............................................................42

5.7 Job Search Efficiency Index 2 (JSE2) -2006 .................................................................... 44

5.7.1 Using new job search methods ............................................................................. 44

5.7.2. Job Search Efficiency Index 2 (JSE2) (1998-2006) ......................................................47

6. Determinants of Women's Job Search Behavior in Egypt .............................................................4

6.1 Personal Characteristics ...................................................................................................4

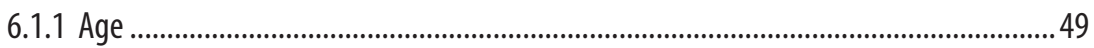

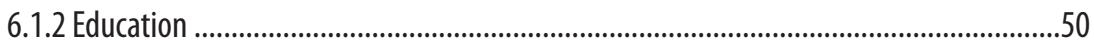

6.1.3 Unemployment Duration ...........................................................................................

6.1.4 Previous Work Experience .......................................................................................

6.2 Household Characteristics ...............................................................................................

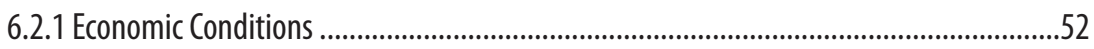

6.2.2 HH size and presence of children ...............................................................................5

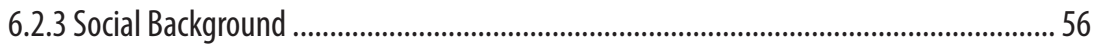

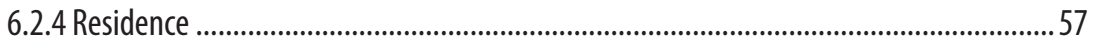

6.3 Labor Market Conditions ..................................................................................................

6.4 Economic Model to Estimate Determinants of Women's Job Search Behavior .........................58

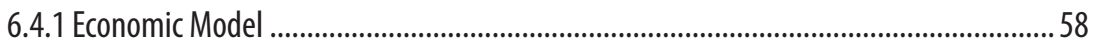

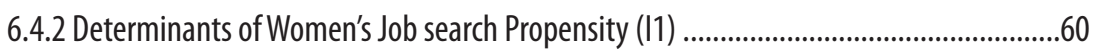

6.4.3 Determinants of Women's Job search Intensity (12) ..................................................62

6.4.4 Determinants of Women's Job Search Methods ..........................................................63

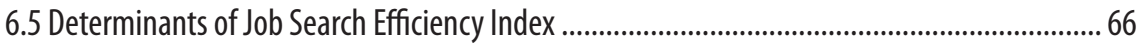

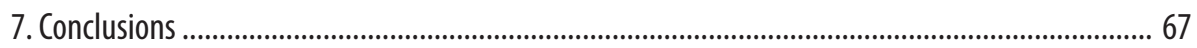

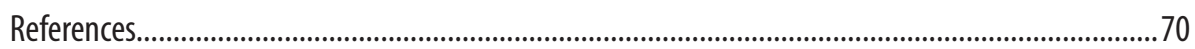

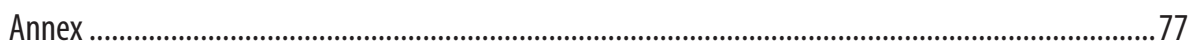




\section{Abstract}

This study evaluates the difference between male and female job search behavior in the Egyptian labor market and the changes in this behavior between 1998 and 2006, in order to examine the effect of transition toward a market-oriented economy on job search activity. The paper also investigates the determinants of women's job search behavior. The empirical analysis is based on two data sets; the Egypt Labor Market Survey of 1998 and the Egypt Labor Market Panel Survey of 2006. The results show that between 1998 and 2006, the unemployed have been more active in their job search. Nevertheless, the results reveal three alarming facts that raise worries about women labor force participation and their future labor market outcomes. Women were less active job searchers than men in 1998 and 2006. Moreover, the gender gap in job search has widened between 1998 and 2006. This gap is even wider when excluding registration in government employment offices from the set of job search methods used. Analyzing job search methods used in 1998 and 2006 by both men and women reveals a major labor market distortion in Egypt. This distortion is three dimensional. The unemployed still depend on registering in a government office to find a job. Informal methods are still the predominant job search methods used. Formal methods, other than registering in the government, depend mainly on contacting employers directly. Non-governmental labor market intermediaries still play a small role in the Egyptian labor market. Hence, transforming to a market economy has not been accompanied with the necessary transformation in labor market institutions. The analyses of the determinants of women's job search behavior show that there exist an inverse U-shape relationship between age and female job search. Education and previous work experience positively affect female job search. Women from wealthier families, unmarried women, and those living in households with a high dependency ratio are more active in their job search. Also, higher unemployment rates in the labor market result in a more active job search.

\section{Introduction}

Labor economics places much emphasis on job search behavior. Job search is a vital activity in the labor market. The intensity and strategies used play an influential role in determining the job seeker's future status in the labor market. 
In the market economy where job seekers cannot depend on the public sector to provide work, the job seeker should be more active in job search and use multiple search methods, rather than relying on a single method or strategy.

Raising job search propensity and intensity seems to be more important for women if they seek to enhance their economic participation and opportunity. Economic theories suggest that there are a lot of possible explanations for the gender gap in unemployment rates. On the supply side, one of the main explanations is that women have lower job search intensity; they dedicate fewer resources to their job search.

In Egypt, there are several reasons that lead to making the analysis of job search behavior in the Egyptian labor market, especially women's job search behavior, of great importance. First: the transition to a marketoriented economy has significantly affected the Egyptian labor market. Access to jobs has become more difficult and requires more job search activities as job seekers cannot any more depend on the public sector for employment. Thus, job search has become an integral part of labor market activity. Second: women are negatively affected more than men by these changes as they used to depend mainly on the government and the public sector. The unemployment rate for women is 2.5 times that of men. Women are more likely to suffer unemployment. The situation is much worse for young women, the unemployment rate for women between ages I5 and 29 is $40.2 \%$ (CAPMAS, 2008). Moreover, women are less likely to escape vulnerable employment.

This leads to the decline in the labor force participation rate among educated women (Assaad, 2007). It is therefore more important to raise job search intensity and improve job search effectiveness for women to avoid unemployment in Egypt from becoming more concentrated among women.

However, there is insufficient empirical information on job search behavior in Egypt. Different studies on job search have emerged in the last two decades. The majority of these studies analyzed job search behavior in developed countries (Holzer, I988, Blau and Robins, I990, Hashimoto, 2004 in the US; Gregg and Wadsworth, 1996, and Böheim and Taylor, 2002 in UK; Osberg, 1993 in Canada; Weber and Mahringer, 2002 for Austria; Lindeboom, Van Ours and Renes, 1994 for the Netherlands, Eriksson, Lilja and Torp, 2002 for Denmark, Finland, and Norway). Fewer studies analyzed job search behavior in developing countries and in economies in transition such as Addison and Portugal, 200I for Portugal; Woltermann, 2002 for Brazil; and Masagué, 2008 for Argentina. For CEECs, the search literature tends to focus on the duration of the search and the effect that unemployment benefits has on it (Ham Svejnar and Katherine Terrell, 
I 998 for the Czech and Slovak labor markets; Lubyova and Van Ours, 1997 for the Slovak Republic; Hinnosaar, 2004 for Estonia; Smirnova, 2003 for Russia). Nevertheless, there is little work in Egyptian literature that explicitly analyzes job search behavior. Wahba and Zenou (2005) study the impact of the size and the quality of social networks on the probability finding a job in Egypt using the 1998 Labor Market Survey.

This study responds to the gap in the empirical literature with respect to the in-depth study of women's job search behavior in Egypt by analyzing the job search behavior and the determinants of search methods, during 1998-2006, an important era of transition in the whole economy, and of the labor market in particular.

\subsection{Objectives}

This study examines the determinants of job search behavior, search intensity, and search methods used by the unemployed in Egypt, focusing on women. It has three main objectives, first: evaluating the difference between men's and women's job search behavior in the Egyptian labor market; second: evaluating the changes in job search behavior (1998-2006), to examine the effect of transition towards a market-oriented economy away from the public sector employment guarantee on the job search activity of both men and women, third: examining the determinants of women's job search behavior.

\subsection{Methodology}

The study uses data from the Egypt Labor Market Panel Survey of 2006 (ELMPS 06) and the Egypt Labor Market Survey of 1998 (ELMS 98). The two surveys are nationally representative surveys. The two surveys provide information on job search methods used by unemployed workers.

The study assesses job search behavior on three main dimensions: (I) job search propensity, (2) job search intensity, and (3) job search method choice. Several indices are constructed to assess job search behavior.

A comparative descriptive approach is used to analyze the difference between men's and women's job search behavior in the Egyptian labor market, between 1998 and 2006, with respect to job search propensity, intensity, strategies, and efficiency.

The effects of personal characteristics, household characteristics and labor market conditions on women's job search behavior are examined using logistic regression.

The paper is organized as follows: Section $\mathrm{I}$ is the introduction; Section 2 provides a theoretical framework for the study of job search behavior; Section 3 focuses on job search behavior and the gender gap in the labor 
market; Section 4 describes the data; Section 5 evaluates job search behavior in Egypt from a gender perspective (1998-2006). In section 6 determinants of women's job search behavior are analyzed. Section 7 concludes.

\section{Theoretical Framework}

\subsection{Job Search}

Labor economics places great emphasis on the job search as a vital activity in the labor market.

The main purpose of this activity is to obtain employment while information about employment opportunities is imperfect and costly to acquire (Smith, 2003; McQuaid and Lindsay, 2005; Rones, I983; Zaretsky and Coughlin, I995; and Marquez and Ruiz-Tagle, 2004).

\subsection{Job Search Behavior}

A job search entails three main decisions: The first is whether or not to search at all, known as the job search propensity. However, searching for a job is not enough, success depends on the intensity with which the worker searches, and the choices he or she makes (Smirnova, 2003).

The second decision is how intensively to search. The literature presents many alternatives to measure job search intensity. Most studies have measured job search intensity using the number of job search methods (Holzer, 1988; Lemaitre, I992; Koning, van den Berg and Ridder, I997; Boheim and Taylor, 2002; Smith, 2003; Smirnova, 2003; Masagué, 2008; Salas-Velasco, 2007; and Brown and Taylor, 2008). Other measures used include the number of job applications made during the reference period (Gautier, González and Wolthoff, 2007) and the time spent searching (Krueger and Mueller, 2008). The method used depends mainly on the data available.

The third decision is which methods to use. Workers are faced with many job search methods, including (BLS, 2008) personal contacts (friends, family, neighbors, acquaintances, teachers, former workers), school career planning and placement offices, contacting employers, advertisements ("job wanted" ads), internet resources (job hunting web sites), professional associations, labor unions, state employment service offices, community agencies (nonprofit organizations offer counseling, career development, and job placement services, generally targeted to a particular group, such as women), private employment agencies and career consultants, and 
internships (job seekers may find jobs with organizations with which they have interned or volunteered).

Job search methods may be classified into two main groups, formal and informal methods. Formal job search methods include using a formal intermediary like public or private employment services, newspaper advertisements, and the direct contact with the employer without intermediary; while informal methods are socially based, where job seekers use an informal intermediary like friends and relatives (Koning, van den Berg and Ridder, 1997 and Nasser and Abouchedid, 2006).

There is no general agreement in the job search literature concerning the best job search method. These methods differ in both costs (time and monetary costs) as well as benefits (getting job offers and the type of these jobs). In addition, their effectiveness differs in different labor markets (Koning, van den Berg and Ridder, I997; Marquez and Ruiz-Tagle, 2004; and Boheim and Taylor, 2002).

The empirical results are mixed. According to some empirical literature (Rees, 1966; Granovetter, 1974; Lindeboom Van Ours and Renes, I994; Addison and Portugal, 200I; Osberg, 1993; Koning, van den Berg and Ridder, 1997; Margolis and Simonnet, 2003; Loury, 2006; and Nasser and Abouchedid, 2006) informal search methods are better than formal methods. They are much easier and their costs are lower. In addition, they are considered quicker than other methods and yield better labor market outcomes. Most jobs are obtained through these methods; they are more productive in generating acceptable job offers and reliable information about the job, and more effective in matching employed workers and vacancies. Returns on jobs found through personal contacts are found in some empirical studies to be higher than jobs found through formal channels. Some studies (Koning, van den Berg and Ridder, 1997) show that these methods have also systematic advantages in terms of non-wage characteristics of job offers. Several other studies (Sagen, Dallam and Laverty, 1999), have found informal methods to be the most effective job procurement method. On the other side, some formal methods are found to be ineffective, including the public employment service (Lindeboom, Van Ours and Renes, 1994; Holzer, I988; Addison and Portugal, 200I).

In contrast, several other empirical studies show that formal search methods are better than informal methods. According to these studies, people who depend on their social networks to find employment are those looking for lower skill occupations (Antoninis, 2004). Searching through these methods results in neither wage nor quality advantage (Koning, van den Berg and Ridder, 1997; Gregg and Wadsworth, 1996) or in jobs of low quality, low wages-lower by $4^{-} 7 \%-($ Bentolila, Michelacci and Suarez, 2004; 
Loury, 2006), job instability and less job satisfaction (Green, 2009 and Loury, 2006). Formal methods were found in a number of these empirical studies, conducted mainly in developed countries to be more effective (Bentolila Michelacci and Suarez, 2004; Kucel and Byrne, 2008), result in higher wages (Hashimoto, 2004). The public employment service was found to be a very effective job search method in two developed countries; the UK and Canada (Gregg and Wadsworth, I996; Osberg, I993).

In developing countries, there are a few numbers of studies on job search behavior. However, these studies have shown that the most used search methods are the informal ones, mainly social contacts (Marquez and Ruiz-Tagle, 2004; Nasser and Abouchedid, 2006). On one hand, entrepreneurs used to rely on social networks in hiring decisions as the low quality of education weakens the strength of signals sent by job seekers, thus depriving employers of an ordinary screening tool in hiring decisions. On the other hand, workers with a stable job consider it their duty to inform members of their kin or village about such opportunities (Antoninis, 2004). In addition, labor markets in developing countries are usually poorly institutionalized on the contrary to labor markets in developed countries.

In contrast, in developed countries where labor markets are better institutionalized, formal methods come first on the list of job search methods used by unemployed job seekers. This is evident in the British labor market (Gregg and Wadsworth, 1996; Boheim and Taylor, 2002; Marquez and Ruiz-Tagle, 2004). The same applies to France (Sabatier, 2000), the US, and Canada (Holzer, I988; Osberg, 1993). However, informal methods are also important in developed countries; in several OECD countries, many surveys report that around $50 \%$ of workers have obtained their job through informal networks (Ponzo and Scoppa, 2008).

In addition to traditional job search methods, new methods have emerged and have been increasingly used. The internet has changed job search activities since the late I990's. It has many advantages that make job search behavior more efficient including (Stevenson, 2008; Autor, 200I, 2008; Kuhn and Skuterud, 2002): First: Reducing job search time and monetary costs of both acquiring information about jobs and applying to these jobs, to those who are equipped with the suitable technological skills needed to use such a method. Second: it is more effective in providing information to the job seeker; about the characteristics of the job and the firm. This allows the unemployed to better target their job search activities. Third: it provides needed assistance to those who lack informal contacts and their social networks are poor. Workers are integrating online job search into their regular search process. This is especially true for the higher educated. These new job search methods are not substitutes for 
the traditional ones, they have increasingly become complementary to traditional job search methods; job seekers may submit their resume and look at job ads online. Concerning its effects on labor market outcomes, there is no general agreement on the effect of internet job search on labor market outcomes. While some studies have shown that it significantly improves search outcomes on dimensions such as job quality and wages especially among women (Paik, 2008), other empirical studies suggest that unemployed internet job searchers do not become reemployed more quickly than unemployed persons who do not look for work online (Kuhn and Skuterud, 2004).

\subsection{Job Search Behavior and Labor Market Outcomes}

Job search behavior significantly affects the job seeker's labor market outcomes in terms of:

\subsubsection{Employability}

Job search behavior affects job seeker's employability both directly and indirectly.

Concerning its direct effects; job search is one of the main factors affecting the individual's employability.

The probability of a job seeker getting a job depends on both labor supply and demand factors, the range of broad employability factors that were generally identified in literature. One of these factors is the intensity and effectiveness of job seekers' job search (McQuaid, 2006; Kanfer, Wanberg and Kantrowitz, 200I; Van Hooft et al., 2005). The positive relationship between job search intensity and the probability of receiving and accepting a job offer is a common finding in both theoretical and applied literature.

$$
\mathrm{p}_{\mathrm{o}}=\mathrm{p}_{\mathrm{o}}(\mathrm{d}, \mathrm{s})
$$

Where $p_{o}$ is the job offer probability, $d$ is the level of demand in the labor market and $\mathrm{s}$ is the intensity of search activity undertaken by the job seeker, $\mathrm{p}_{\mathrm{o}}$ is increasing in both $\mathrm{d}$ and $\mathrm{s}$ (Eriksson, Lilja and Torp, 2002).

Empirical evidence suggests that the higher the job search intensity is, the higher is the probability of becoming employed, the faster the job seeker gets a job and thus the lower the unemployment duration. This is simply because the higher job search intensity is, the more information on vacancies the job seeker gets, which is likely to result in a higher probability of receiving a job offer. The effect of search intensity on employability has been found to be positive and statistically significant (BLS, 2008; Mitra, 2007; Barron and Gilley, 198r; Chirinko, 1982; Kahn and Low,1988; Holzer, I988; Bortnick and Hanison, 1992; Gregg and 
Wadsworth, 1996; Marquez and Ruiz-Tagle, 2004; McQuaid and Lindsay, 2005; McQuaid, 2006; Sabatier, 2000; Boheim and Taylor, 2002; Smith, 2003; Addison and Portugal, 200I; Hinnosaar, 2004; Bloemen, 2005; Van Hooft et al., 2005; Salas-Velasco, 2007; Boman, 2008). This positive effect was more pronounced among the most vulnerable in the labor market, such as new entrants and job losers (Kanfer, Wanberg and Kantrowitz, 200I; Van Hooft et al., 2005). For instance, a study of the transition from higher education to work in nine European countries (Salas-Velasco, 2007) found that individual job searches bear a significant relationship to the probability of finding a job.

In addition to job search intensity, more effective search methods can reduce the unemployment rate simply by increasing the efficiency of jobworker matches (Marquez and Ruiz-Tagle, 2004; Holzer, 1988; Gregg and Wadsworth, 1996; McQuaid and Lindsay, 2005; Bortnick and Hanison, 1992; Blau and Robins, 1990; Stoll and Raphael, 2000; Addison and Portugal, 2OOI; Woltermann, 20O2). For instance, in the US labor market, it was found that differential search quality explains between approximately $25^{-} 40 \%$ of difference in employment rates (Stoll and Raphael, 2000).

In addition to its positive direct effects on employability, job search behavior affects employability significantly through indirect channels (Figure I).

Figure 1: Job Search Behavior, Reservation and Expected 'Wages and Employability

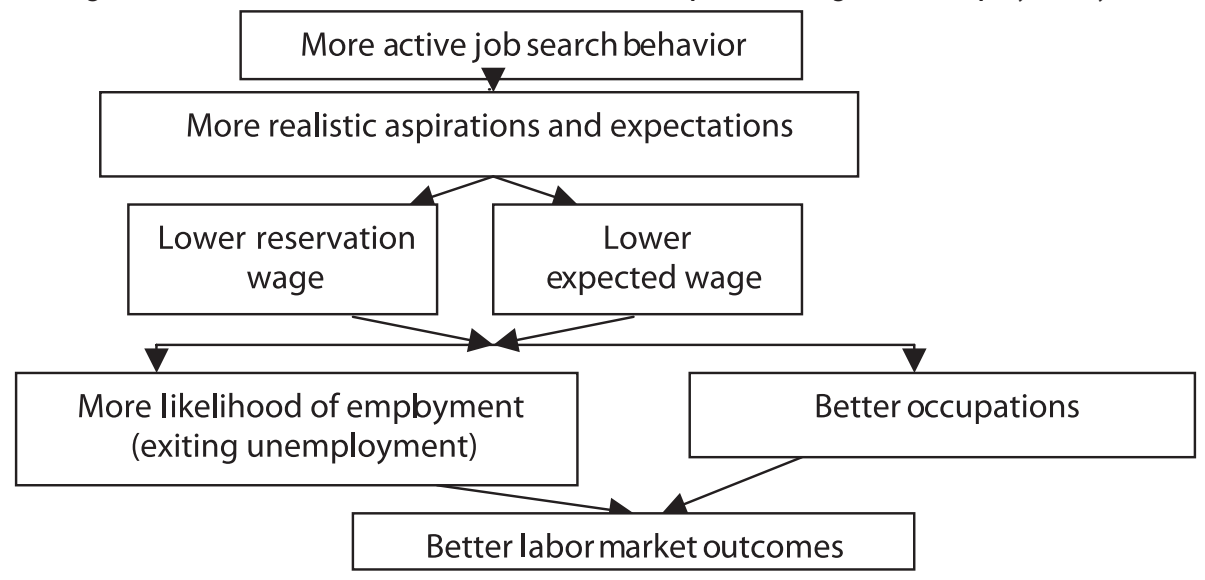

Source: conducted by the author.

According to job search theory, the probability of leaving unemployment is the product of the probability of receiving a job offer times the probability of accepting it. The latter is affected, among other things, by

1 The expected pay to get for the job, the job seeker is looking for. 
the job seeker's reservation wage (Salas-Velasco, 2007; McQuaid, 2006); an individual exits unemployment once he/she receives a wage offer equal to or in excess of the reservation wage. Thus, the unemployed who have a reservation wage below their predicted wage have a higher probability of future employment and subsequently higher wages. In the UK, it was found that those with reservation or expected wages below their predicted market wage are characterized by a statistically significant higher probability of future employment and are likely to receive higher net wages than their matched counterparts (Brown and Taylor, 2008). Job search results in realistic wage aspirations. The reservation wages of unemployed job seekers are influenced by their knowledge of the wage offer distribution as well as job availability. Job searches serve to inform individuals about the wage offer distribution. Thus, job search activity is found to influence the probability of having a reservation wage lower than the predicted wage. The index of job search intensity was found to be positively associated with the probability that the reservation wage is below the predicted market wage (Brown and Taylor, 2008).

\subsubsection{Job Quality}

The job search behavior affects not only the probability of being employed, but also the quality of the obtained employment which is an important employment outcome. Previous research (Saks and Ashforth, 2002; Werbel, 2000; Van Hooft et al., 2005; Kluve et al., 2007; Tasci, 2008) has indicated that job search behavior is an important predictor of employment quality. Job search intensity positively affects employment quality, because a more intense job search is likely to result in more job opportunities and more information on these opportunities allowing the job seeker to choose the best alternative. In addition, it enhances the matching efficiency between vacancies and unemployed job seekers.

It is not only the job search intensity that affects the quality of the obtained employment, but also the job search strategy. Different empirical studies in both developed and developing countries have shown that the type of job search method used significantly affect labor market outcomes of job seekers, the probability of exiting unemployment into informal employment or finding a job in the formal sector and the future occupational status (Holzer, I988 in the US labor market; Blau and Robins, I990 in the US labor market; Gregg and Wadsworth, 1996 in the British labor market; Addison and Portugal, 2OOI in the Portuguese labor market; and Woltermann, 2002 in the Brazilian labor market). 


\subsubsection{Returns}

Job search behavior affects future work returns in two different ways; first: through the matching process, and second through shortening the unemployment spell (Figure 2).

Figure 2: Job Search Behavior and Work Returns

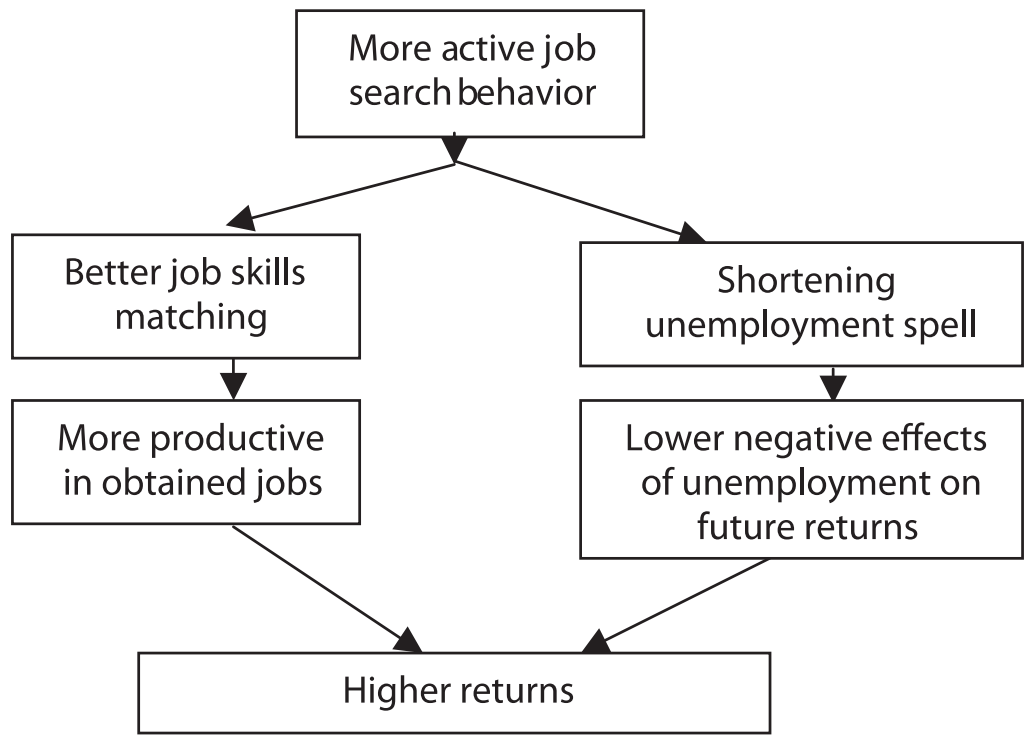

Source: conducted by the author.

First: labor market search models imply that the more intensely a labor market participant searches for a new job, the higher is his potential labor income. The positive relationship stems from the matching process; if the job search intensity is higher, the job seeker gets more job offers, which increases the probability of finding a job which is a good match to his labor market skills. Thus, persons who search more intensely will be more productive at their future jobs and earn higher salaries (Room, 2004; Bowen and Doyle, 2004; Boheim and Taylor, 2002).

Second: as previously mentioned more active job search results in higher probability of getting a job and lower unemployment duration. The duration of unemployment was found to negatively affect the job seekers' future returns. It was found that an unemployment episode reduced earnings upon re-employment by around Io\%. If a worker's spell of unemployment lasted for a year, then earnings on re-employment fell by a further is $\%$ giving an overall reduction of about $20 \%$. Even after two years of continuous employment, earnings for the previously long-term unemployed worker were still some $13 \%$ below those of somebody who had never experienced unemployment (results of Gregory et al., 200I 
as cited in Smith, 2003). Another study (Arulampalam, 200I as cited in Boheim and Taylor, 2002) provided evidence on this negative effect, suggesting that unemployment results in earnings some Io\% lower than pre-unemployment earnings. This effect is found to persist. Thus, higher job search intensity and using efficient job search strategy is necessary for the unemployed so as to avoid earnings reductions and further scarring on re-entry to work through shortening unemployment duration.

\subsection{Main Determinants of Job Search Behavior}

Despite the significant impact of job search behavior on job seekers' labor market outcomes, it was found that apart from a number of rather descriptive analyses of job seekers' use of different channels of search, relatively few empirical studies attempt to explain differences in individuals' search effort; i.e. what are the main factors determining job search behavior? Some notable exceptions are Barron and Mellow (I979), Barron and Gilley (1981), Chirinko (I982), Holzer (I988), Lindeboom, Van Ours and Renes (I994), Eriksson, Lilja and Torp (2002). Few studies have been conducted to analyze main determinants of job search behavior in developing countries, none in Egypt.

The main determinants of job search behavior may be classified in three main groups: personal characteristics, household, and labor market conditions:

\subsubsection{Personal Characteristics}

Personal characteristics are found to be important determinants of individuals' search behavior. The main personal characteristics that were found to have significant impact on job search behavior include:

- Age: Different empirical literature has shown that age is one of the main determinants of job seekers' search behavior. The young are usually more active in job search. The study of search behavior in three Nordic countries (Eriksson, Lilja and Torp, 2002) showed that there is evidence that elderly workers are less likely to search and when they do, they use fewer channels of and less time on searching. However, in Turkey, it was observed that there is an inverse- $U$ shaped relation between age and job search intensity (Tasci, 2008).

- Education: Both theoretical and empirical literature emphasizes the positive significant effect of education on job search behavior. Higher education levels are expected to result in both a more intense and more efficient job search.

Theory hypothesizes that the higher the educational attainment is, the higher the individual's expected lifetime earnings and thus the higher the motivation to search for a job (Smirnova, 2003; Smith, 2003). 
Different empirical literature have shown that the likelihood of engaging in a job search is estimated to increase for people with higher education levels and they tend to be more active in their job search than those with lower education levels (Smirnova, 2003; Hinnosaar, 2004; Bergin, 2009; Boheim and Taylor, 2002)

In addition to being more active in the job search, the highly educated tend to be more efficient job searchers; they tend to search in geographically larger labor markets nationally and internationally, while the less educated are more likely to search more locally mainly through their social contacts (family, friends) (Boheim and Taylor, 2002; Bergin, 2009). Moreover, the highly educated search strategies tend to be broader; as education has been found to affect the choice of the job search methods. The higher educated tend to use new search methods far more extensively than the lower educated; as using these new methods requires some level of technological skill, (Stevenson, 2008; Autor, 200I; Woltermann, 2002; Kuhn and Skuterud, 2004; Fountain, 2005). The higher the education level of the job seeker, the more likely he or she is to use formal search methods rather than informal ones. Employers also tend to recruit through informal referrals for unskilled jobs which are more likely to be filled by the lower educated (Smith, 2003; Koning, van den Berg and Ridder, I997; Chapple, 2006; Sackey and Osei, 2006; Marquez and Ruiz-Tagle, 2004; Boheim and Taylor, 2002; Tasci, 2008; Ponzo and Scoppa, 2008).

The positive effect of education on job search intensity and strategies has been found to be more significant among women than among men (Van Hooft et al., 2005; Tasci, 2008).

- Unemployment Duration: The job search effort was found to vary with time. However, the results about the effect of unemployment duration on job search behavior are mixed (Hinnosaar, 2004; Masagué, 2008; KonleSeidl, Eichhorst, and Zingerle, 2007; Marquez and Ruiz-Tagle, 2004; Eriksson, Lilja and Torp, 2002). The effect of unemployment duration was found to differ from one labor market to another. It may have a negative effect, leading the unemployed job seekers to decrease their search effort because of discouragement; loss of hope of finding a job, especially when the job seeker finds it is more difficult to afford search costs due to decreased savings. On the other hand, the longer the unemployment duration, the more difficult for the job seeker to find a job as employers take the duration of the unemployment as a negative signal about the unemployed job seeker's human capital and qualifications. On the contrary, the longer unemployment duration of job seekers may result in more intense search effort if the job seekers rely on receiving unemployment benefits for which his/her eligibility ends after a certain period of time. 
The unemployment duration affects also the search strategy (Marquez and Ruiz-Tagle, 2004; Boheim and Taylor, 2002). The long duration of unemployment may change the search methods they use to make their search more effective. Those unemployed for a long time tend to rely more on formal methods, such as employment agencies and direct contact with employers.

- Previous Work Experience: Previous work experience affects both search intensity and methods. However its effects on search methods have been found to be more pronounced.

Concerning search intensity, it has been found that both those who previously worked in elementary occupations and those in higher positions tend to search less (Hinnosaar, 2004). It has been found that individuals with greater experience in the labor market would depend more on informal methods. Those who previously worked in the informal sector are more likely to depend on informal search methods. Conversely, those who have work experience in the formal sector depend more on formal search methods (Smirnova, 2003; Marquez and Ruiz-Tagle, 2004; Koning, van den Berg and Ridder, 1997).

\subsubsection{Household Characteristics}

A number of household characteristics are also found to be important determinants of individuals' job search behavior, including:

- Economic Conditions: Household economic conditions affect both job search intensity and methods. Household income reflects the level of financial hardship which has been found to determine job search intensity (Boheim and Taylor, 2002). The lower household income implies more pressures on the unemployed to be more active in the job search. On the contrary, those individuals from high income households have less motivation to search for work. Searching for employment requires that the expected utility of searching for employment be higher than the utility of leisure, and since leisure is a normal good and job search is a time consuming activity, wealthy people are less likely to participate to the labor market. Job seekers are those, among the non-working individuals, with a lower value of leisure (Sestito and Viviano, 2008).

Concerning search methods, it was found that the better the household economic conditions are, the more likely they are to have better social contacts that provide access to higher levels of employment and thus the more likely to depend on informal search methods (McQuaid, 2006; Nasser and Abouchedid, 2006).

-Household Size and the Presence of Children: Bigger households and a large number of children imply a high dependency ratio and thus put more pressure to search for work. However, the effect of the presence of 
children has been found to differ significantly between men and women. In the case of men, it raises job search intensity as the result of the need to support those children. In contrast, the presence of children has been found to reduce women's job search intensity (Masagué, 2008). However, some empirical studies have shown that having young children is associated with a lower probability that the person searches at all (Eriksson, Lilja and Torp, 2002).

- Residence: Both search theory and empirical literature suggests that urban residents are more likely to search more intensively than rural residents. This difference in job search behavior between urban and rural areas reflects differences in both job search costs and benefits. On one hand, the job search is more likely to pay off in urban areas, as there are more developed labor markets in which it is more likely that there are a lot of good high return jobs that are worth searching for, more than in rural areas. On the other hand, costs of the search are lower in urban labor markets due to the high density of employers and lower transportation costs (Smirnova, 2003; Tasci, 2008; Yankow, 2009).

\subsubsection{Labor market conditions}

In addition to personal and household characteristics, labor market conditions determine job search behavior. The main labor market conditions that affect job search behavior include:

- Unemployment Rate: The job search intensity has been found to be inversely related to the unemployment rate. It is lower in labor markets with very high unemployment rates and few job opportunities available which discourage the unemployed. In contrast, it increases in labor markets where job competition declines and the probability of receiving a job offer rises as job search tends in this case pay off (Salas-Velasco, 2007; Hinnosaar, 2004; Marquez and Ruiz-Tagle, 2004; Boheim and Taylor, 2002; Barron and Mellow, 1979; Barron and Gilley, I98r; Eriksson, Lilja and Torp, 2002; Bowen and Doyle, 2004). However, one empirical study in Turkey found that increases in the unemployment rate increase the job search intensity (Tasci, 2008). The unemployment rate has also been found to affect job search methods; as informal methods tend to be used more intensively in labor markets with high unemployment (Ponzo and Scoppa, 2008).

- Unemployment Benefits: Receiving unemployment benefits should improve the effectiveness of job search by enabling the unemployed to finance job search activity (Blau and Robins, I990; Smith, 2003). However both theoretical and empirical literature suggests that unemployment benefits have a negative effect on job search intensity. In the search theory, welfare benefits cause a decline in unemployed job seekers' search 
intensity as they present negative work incentives, encourage job seekers to wait for better job offers, reduce the pressure to accept any suboptimal job offer, make withdrawal from the labor force more attractive at the margin between job search and complete leisure, and prevent the timely downward adjustment of reservation wages as they provide an implicit wage floor. Thus, the higher the level and the duration of alternative income from social benefits are, the lower the job search intensity. When the benefit system is so generous that the income from unemployment and other associated welfare entitlements exceeds the individual's reservation wage, the unemployed worker stops searching for a job and chooses to live off state benefits indefinitely (Smith, 2003; Ljungqvist and Sargent, I995; Freeman, 2008; Eichhorst, Feil, Christoph Braun, 2008a; Eichhorst and Regina Konle-Seidl, 2008b; Gaure, Røed and Westlie, 2008). Different empirical studies emphasize this negative effect (Hinnosaar, 2004 for Estonia; Krueger and Mueller, 2008 for the US; Khan, 2009 for 8 European countries; Gaure, Røed and Westlie, 2008 for Norway; Katz and Meyer, I 988 for the US). They have also shown that job search intensity tends to increase sharply among those eligible for unemployment benefits prior to the end of benefit entitlement.

\section{Job Search Behavior and the Gender Gap in the Labor Market}

\subsection{Gender Gap in the Labor Market}

Women generally are in an unfavorable position in the labor market. On one hand, they are less active than men; while the world female labor participation rate was only $52.6 \%$ in 2008 compared with $77.5 \%$ for males (ILO, 2009a). In addition, women are more vulnerable to unemployment, while the world female unemployment rate was $6.2 \%$; it was $5.7 \%$ among males. In North African countries, the gap is even wider ( $15 \%$ and $8.1 \%$ in 2008). In addition, the percentage of vulnerable employment among women is also higher ( $5 \mathrm{I} .3 \%$ and $48.2 \%$ in 2008$)$ (ILO, 2009b).

\subsection{Gender Gap in Job Search Behavior-Different Hypotheses}

The economic theory suggests that there are a lot of possible explanations for gender gaps in the labor market. On the supply side, one of the main explanations is that females have a lower job search intensity (Masagué, 2008; Azmat, Güell and Manning, 2004). There are different 
hypotheses explaining gender gaps in job search. These hypotheses may be divided into four main groups:

\subsubsection{Social Roles Hypotheses}

The household responsibility hypothesis (McQuaid, 2006; and Masagué, 2008) argues that given traditional family arrangements, female members of the household have more domestic responsibilities than males. This, in turn, results in: a) having less time than males to search and also to work, b) having higher reservation wages than males, especially in case of presence of children, as it is found to lower male reservation wages and increase female reservation wages. The labor supply theory (Smirnova, 2003) suggests that female job search behavior might be disproportionately affected by the presence of young children. Another hypothesis argues that women have less spatial flexibility in the search (Van Hooft et al., 2005; Eriksson and Lagerström, 2008; Stoll and Raphael, 2000). Due to their domestic responsibilities, women are obliged to search close to their current home especially if they have children. In addition, as women have more alternatives to devote their time to than men; they have an option that is largely unavailable to men, that is to be inactive, having zero search intensity (Kondylis and Manacorda, 2006; Bergemann and van den Berg, 2006).

\subsubsection{Differences in Job Search Costs Hypotheses}

Job search costs are argued to be higher for women. On one hand, women face more difficulties when job searching. While it is easier for men to find a job through their social networks, women have fewer work contacts in their social networks. Thus, women find it more costly to get information about opportunities in the labor market and to get a job (Campbell, I988; Fischer and Oliker, I983; Moore, I990; Straits, I998; McDonald and Elder, 2006; ILO, 2008). On the other hand, it is argued that as women have a larger share of household work, including taking care of children, ill, and disabled persons in the household, they have a higher opportunity cost of searching than men (Room, 2004).

\subsubsection{Differences in Job Search Benefits Hypotheses}

One of the main determinants of job search activity is search benefits in terms of job finding prospects and expected returns which are lower for women than for men (Orazem, Werbel and Mcelroy, 2003; Room, 2004; Eriksson and Lagerström, 2008). On one hand, women anticipate discriminatory treatment in the labor market, thus they lower their reservation wage, which in turn, negatively affects their search intensity. 
On the other hand, they on average, earn less than men, and thus have less incentive to search.

\subsubsection{Differences in Personality Characteristics Hypotheses}

Differences in personality characteristics between men and women result in differences in search behavior. Evidence from behavioral economics (Room, 2004) implies that women are in general more riskaverse than men, which leads women to lower their reservation wage. In addition, while education has a more significant positive effect on women's search intensity than men's, women tend to be less educated and less confident in their abilities having unusually high perceptions of discrimination relative to actual measures of market discrimination (Orazem, Werbel and Mcelroy, 2003). These differences result in lower search intensity for women than for men.

\subsection{Gender Gap in Job Search Behavior-Empirical Evidence}

Most of the empirical literature on job searches are in developed countries, e.g., Bortnick and Hanison, 1992; Stoll and Raphael, 2000; Kuhn and Skuterud, 2004, 2002; Orazem, Werbel and Mcelroy, 2003; Hashimoto, 2004; Bowen and Doyle, 2004; Loury, 2006; McDonald and Elder, 2006; Krueger and Mueller, 2008; Stevenson, 2008; and Yankow, 2009 for the US; Böheim and Taylor, 2002; and McQuaid, 2006 for the UK; Fahr and Schneider, 2004 for Japan and six European countries; Hinnosaar, 2004; and Room, 2004 for Estonia; Bentolila Michelacci and Suarez, 2004 for the US and European countries; Koning, van den Berg and Ridder, 1997; Bloemen, 2005; and Van Hooft et al., 2005 for the Netherlands; Micklewright and Nagy, 1999 for Hungary; Eriksson, Lilja and Torp, 2002 for three Nordic Countries; Gaure, Røed and Westlie, 2008 for Norway; Khan, 2009 for eight European countries; Green, 2009 for Australia; Ponzo and Scoppa, 2008 for Italy; Margolis and Simonnet, 2003; for France. Only a few of the empirical literature are on countries in transition, e.g., Smirnova, 2003 for Russia. The same applies to developing countries, e.g., Nasser and Abouchedid, 2006 for Lebanon; Woltermann, 2002 for Brazil; Tasci, 2008 for Turkey.

Most of these studies focus on job search methods used and their effectiveness; i.e. formal versus informal, and the use of new search methods, e.g. Stevenson, 2008; Hashimoto, 2004; Fahr and Schneider, 2004; Woltermann, 2002; Bentolila, Michelacci and Suarez, 2004; Kuhn and Skuterud, 2004; Koning, van den Berg and Ridder, I997; McDonald and Elder, 2006; Bortnick and Hanison, I992; Marquez and Ruiz-Tagle, 2004; Green, 2009; Ponzo and Scoppa, 2008; Loury, 2006; Van Hooft et al., 2005; Addison and Portugal, 200I; Boheim and Taylor, 2002; Bloemen, 
2005; Micklewright and Nagy, 1999. Other studies are concerned with the impact of labor market policies, e.g. unemployment benefits, on job search behavior, e.g., Hinnosaar, 2004; Krueger and Mueller, 2008; Gaure, Røed and Westlie, 2008; and Khan, 2009. Other studies analyze determinants of job search behavior and the effect of race and gender on it, e.g. Nasser and Abouchedid, 2006; Room, 2004; Yankow, 2009; Orazem, Werbel and Mcelroy, 2003; Stoll and Raphael, 2000; Smirnova, 2003; Kuhn and Skuterud, 2002; Eriksson, Lilja and Torp, 2002; Tasci, 2008; and Bowen and Doyle, 2004. Concerning gender differences in job search behavior, evidence from this empirical literature confirms the hypothesis that differences do exist in job search behavior between males and females. These differences exist in two main aspects of job search:

\subsubsection{Job Search Intensity}

Evidence gathered from empirical literature suggests that females are significantly less active in job search than males (Tasci, 2008; Smirnova, 2003; Eriksson, Lilja and Torp, 2002; Room, 2004; Orazem, Werbel and Mcelroy, 2003). They search less intensively; they spend less time on the job search, use fewer search methods, and have fewer contacts with employers. They become less active when they get married, contrary to males. The martial status variable has been found to have a significant negative effect on women's job search (Bowen and Doyle, 2004).

In addition, if they get a job, females are less likely to do on-the-job search $^{2}$ than men (Bowen and Doyle, 2004; Eriksson and Lagerström, 2008). In case they lose their jobs, females are much less likely than males to start a job search. Besides, if they start a job search and then spend a longer time in this search, they are more likely to give up searching and leave the labor force than males (Micklewright and Nagy, I999).

However, some empirical literature suggests that the gender differences in search intensity do exist but are small (Van Hooft et al., 2005). Some studies found that women generate more job offers per contact, suggesting that women may search more efficiently than men (Orazem, Werbel and Mcelroy, 2003).

\subsubsection{Job Search Methods}

Empirical literature has shown that gender affects not only search intensity but also search methods (Smirnova, 2003; Nasser and Abouchedid, 2006; Eriksson, Lilja and Torp, 2002; Bayer, Ross and Topa, 2005). Females are more likely to use formal methods than males who tend to depend more on informal methods.

2 On-the-job-search is job search while employed. 


\section{Data}

The empirical analysis is based on two data sets: the Egypt Labor Market Survey of 1998 (ELMS 98) and the Egypt Labor Market Panel Survey of 2006 (ELMPS 06). Both the ELMS 98 and the ELMPS 06 are nationally representative household surveys. They were carried out by the Economic Research Forum (ERF) in cooperation with the Egyptian Central Agency for Public Mobilization and Statistics (CAPMAS).

The ELMS 98 was carried out in November and December 1998, on a sample of 4,816 households containing 23,997 individuals. The ELMPS o6 was carried out from January to March 2006, on a sample of 8,349 households containing 37,I00 individuals. The 2006 sample contained 3,684 households from the original ELMS 98 survey, 2,I67 new households that emerged from these households as a result of splits, and a refresher sample of 2,498 households ${ }^{3}$. The data are weighted by sampling weights.

The questionnaires for the two surveys were designed to ensure comparability of the data over time. In the two surveys, there were three main questionnaires: I) the household questionnaire; 2) the individual questionnaire; 3) the family enterprise questionnaire. The two surveys collected information on individual characteristics, employment characteristics, unemployment, and mobility. Regarding job search behavior, the two surveys collected information on job search methods used by unemployed workers. The job search questions applied to all unemployed individuals whether they had worked before or not. They were asked whether or not they had searched for a job during the previous three months using a certain job search method, where I4 job search methods were identified. In the ELMPS o6, questions about using new search methods as complementary to traditional methods were added.

\section{Job Search Behavior in Egypt (1998-2006)-A Gender Perspective}

\subsection{Measures of Job Search Behavior}

To assess job search behavior in Egypt for both males and females, the following measures are used:

3 For more details about the two surveys, refer to (Assaad, 2007 and Barsoum, 2007). 


\subsubsection{Job Search Propensity (I1)}

Job search propensity (I) is measured as the percentage of the unemployed who did a job search. It is measured as follows:

$\mathrm{SU} / \mathrm{U}(\mathrm{I})$

Where: SU and U denote respectively, the unemployed who did a job search and the unemployed.

\subsubsection{Job Search Intensity (I2)}

Job search intensity $\left(\mathrm{I}_{2}\right)$ is measured as the total number of job search methods used by the unemployed. It ranges from o to I4. As previously mentioned, the literature presents many alternatives to measure job search intensity. However, most studies have measured job search intensity using the number of job search methods (Holzer, I988; Lemaitre, I992; Koning, van den Berg and Ridder, I997; Boheim and Taylor, 2002; Smith, 2003; Smirnova, 2003; Masagué, 2008; Salas-Velasco, 2007; Brown et al., 2008). The method used depends mainly on the data available, thus the most suitable way to consider the data available from ELMPS 06 is the total number of job search methods used.

$$
\mathrm{I}_{2}=\mathrm{m}_{\mathrm{I}}+\mathrm{m}_{2}+\ldots \ldots \ldots \ldots \ldots+\mathrm{m}_{\mathrm{I} 4}
$$

Where: $m_{i}$ is propensity to use the job search method $i, i=I$....I4, $m_{i}$ ranges from o no use to I use.

\subsubsection{Job Search Methods}

Considering job search methods used, different measures are used:

- Propensity to use a formal search method (F); ranges from: o no formal search method was used, and I when at least one formal job search method was used.

- Propensity to use an informal job search method (I); ranges from: o no informal search method was used, and I when an informal job search method was used.

- Using both formal and informal job search methods (I), ranges from $\mathrm{O}$ indicating no job search methods used to 2 indicating using both formal and informal job search methods. $I_{3}$ equals $\mathrm{I}$ if either formal methods are only used or informal methods are only used.

$$
\mathrm{I}_{3}=\mathrm{F}+\mathrm{I} \quad \text { (3) }
$$

- In 2006, the questions about using new search methods as complementary to traditional methods were added. Thus, another indicator was constructed where:

$$
\begin{gathered}
\mathrm{I}_{3}=(\mathrm{F}+\mathrm{I}) * \mathrm{I} \text { if } \mathrm{N}=\mathrm{O} \\
\mathrm{I}_{3}=(\mathrm{F}+\mathrm{I}) * 2 \text { if } \mathrm{N}=\mathrm{I}
\end{gathered}
$$


Where: $\mathrm{N}=\mathrm{O}$ if new job search methods were not used and $\mathrm{N}=\mathrm{I}$ if new job search methods were used as complementary to traditional job search methods.

\subsection{Job Search Behavior Efficiency Indices}

Two composite indices were constructed using the previous three measures of job search behavior:

Fob Search Efficiency Index I ( $\mathcal{H S E I}$ ): JSEI is a composite index that measures the efficiency of job search behavior as follows:

$$
\begin{aligned}
& \text { Where: } \\
& \mathrm{JSEI}=\left(\mathrm{I}_{2 \mathrm{st}+} \mathrm{I}_{3 \mathrm{st}}\right) / 2 \\
& \mathrm{I}_{2 s t}=(\text { value-min. }) \div(\max .-\min .) \text {, min. }=0 \text { if } \mathrm{I}_{\mathrm{r}}=\mathrm{O}, \mathrm{I}_{2 \mathrm{st}} \text { ranges from } \mathrm{O} \text { to } \\
& \text { I (6) } \\
& I_{3 s t}=(\text { value }-\min .) \div(\max .-m i n .), \min .=0 \text { if } I_{I}=0, I_{3 s t} \text { ranges from } O \text { to } \\
& \text { I (7) }
\end{aligned}
$$

Fob Search Efficiency Index 2 ( $\mathcal{H S E 2}$ ): JSE2 is a composite index that measures the efficiency of job search behavior considering using new methods as complementary to traditional ones. It is constructed for 2006 only.

$$
\mathrm{JSE} 2=\left(\mathrm{I}_{2 \mathrm{st}}+\mathrm{I}_{3 \mathrm{st}}\right) / 2
$$

Where: $\mathrm{I}_{3}=(\mathrm{F}+\mathrm{I}){ }^{*}$ if $\mathrm{N}=\mathrm{O}, \mathrm{I}_{3}=(\mathrm{F}+\mathrm{I}){ }_{2}$ if $\mathrm{N}=\mathrm{I}$.

\subsection{Job Search Propensity (1998-2006)}

Table (I) reports job search propensity for both males and females. It shows job search propensity for all males and females and for both young males and females ( $\left.15^{-29}\right)$. The data are weighted by sampling weights. The data illustrates job search propensity, taking into consideration registering in government office.

Table (1): Job Search Propensity $\left(I_{1}\right)$ - with Government-1998-2006

\begin{tabular}{|l|c|c|c|c|}
\hline & 1998 & 2006 & $\begin{array}{c}\text { Test } \\
\text { Significance }\end{array}$ & $2006 / 1998$ \\
\hline Male 15+ & 0.8186 & 0.8858 & 0.000 & 1.08 \\
\hline Female15+ & 0.8341 & 0.8341 & 0.986 & 0 \\
\hline Test significance & 0.000 & 0.000 & - & - \\
\hline Male/female relative gap & 0.98 & 1.06 & - & $\begin{array}{c}(+) \\
\text { reversed }\end{array}$ \\
\hline Total 15+ & 0.8269 & 0.8549 & 0.000 & 1.03 \\
\hline Male 15-29 & 0.8458 & 0.8932 & 0.000 & 1.06 \\
\hline
\end{tabular}




\begin{tabular}{|l|c|c|c|c|}
\hline Female 15-29 & 08381 & 0.8290 & 0.000 & 0.99 \\
\hline Test significance & 0.000 & 0.000 & - & - \\
\hline Male/female relative gap & 1.01 & 1.08 & - & $(+)$ \\
\hline Total 15-29 & 0.8416 & 0.8546 & 0.000 & 1.02 \\
\hline
\end{tabular}

Source: Author's calculations from Egyptian Labor Sample Survey 1998, and the Egypt Labor Market Panel Survey 2006.

The data illustrates that:

- Between 1998 and 2006, job search propensity tended to increase. However, this increase hides gender differences in job search propensity. - Unemployed males are more likely to search for a job than unemployed females. Males' job search propensity is significantly higher than females' job search propensity in 2006 in spite of the fact that female's job search propensity was higher than male's in 1998 .

- The gender gap in search propensity is wider among youth. Young females are the least active in the job search.

- Contrary to males, young females are less active than all females. Young female's search propensity is lower than female's average job search propensity.

- Between 1998 and 2006, the gender gap in job search propensity tended to increase, both among all males and females and also among young males and females. While males' job search propensity has tended to increase, females' search propensity remained the same and young female's search propensity decreased. Young females are not only the least active but also tend to be less active in the job search.

Table (2) reports job search propensity for both males and females, excluding those who depend only in their job search on registering in government office from job searchers; thus for the job seeker who depends only on registering in a government office and does not use any other search method, $I_{I}=0$.

Table (2): Job Search Propensity $\left(\mathrm{I}_{1}\right)$ - without government-1998-2006

\begin{tabular}{|l|c|c|c|c|}
\hline & 1998 & 2006 & $\begin{array}{c}\text { Test } \\
\text { Significance }\end{array}$ & 2006/1998 \\
\hline Male 15+ & 0.7970 & 0.8543 & 0.000 & 1.07 \\
\hline Female15+ & 0.7443 & 0.7579 & 0.000 & 1.02 \\
\hline Test significance & 0.000 & 0.000 & - & - \\
\hline Male/female relative gap & 1.07 & 1.13 & - & $(+)$ \\
\hline Total 15+ & 0.7690 & 0.7965 & 0.000 & 1.04 \\
\hline
\end{tabular}




\begin{tabular}{|l|c|c|c|c|}
\hline Male 15-29 & 0.8291 & 0.8590 & 0.000 & 1.04 \\
\hline Female 15-29 & 0.7571 & 0.7623 & 0.000 & 1.01 \\
\hline Test significance & 0.000 & 0.000 & - & - \\
\hline Male/female relative gap & 1.1 & 1.13 & - & $(+)$ \\
\hline Total 15-29 & 0.7895 & 0.8009 & 0.000 & 1.01 \\
\hline
\end{tabular}

Source: Author's calculations from Egyptian Labor Sample Survey 1998, and the Egypt Labor Market Panel Survey 2006.

Data in table (2) shows that females are far less active in the job search if registering in the government employment office is excluded from job search methods used:

- Between 1998 and 2006, job search propensity excluding registering in government office tended also to increase.

- However, unemployed males are more likely to search for a job than unemployed females. Comparing with the gender gap in search propensity considering registering in government office, the gender gap in search propensity is wider, among all males and females and also among young males and females.

- Among both males and females, job search propensity is higher among youth. Youth tend to be less dependent on registering in the government to find a job.

- Between 1998 and 2006, the gender gap in job search propensity, excluding registering in government office, tended also to increase, both among all males and females and among young males and females, in spite of the fact that both males' and females' job search propensity has tended to increase.

- Contrary to job search propensity including registering in government office, both females and young females have higher job search propensity in 2006 than in 1998.

Analyzing reasons behind not doing a job search among unemployed males and females (Table 3) shows that the most important reason is bad labor market conditions expected. These bad conditions are reflected in believing there are no jobs, being tired of looking for jobs, and believing there are no suitable jobs.

Comparing unemployed females with unemployed males, it is obvious that an expected bad labor market has a more influential effect on females than on males. This is expected due to the transformation in the labor market and the lack of work opportunities in both the government and the public sector, where females, especially educated females, used to find work of what they consider a relatively good quality. 
Other important reasons for females are family conditions; this reflects the traditional family arrangements.

It is worth mentioning that one of the main reasons is the lack of institutional support in job search resulting in lack of awareness about job search methods that may be used and formal labor market intermediaries. In spite of the fact that both males and females recognize the importance of personal connections in getting a job "informal search methods," this reason is more important for males than for females, as males are more likely to depend on informal search methods.

Table (3): Main Reasons for not Doing a Job Search $\left(I_{1}=0\right)$ among the Unemployed-2006

\begin{tabular}{|l|c|c|c|c|}
\hline \multirow{2}{*}{\multicolumn{2}{|c|}{ Reason }} & \multicolumn{2}{c|}{$15+$} & \multicolumn{2}{c|}{$15-29$} \\
\cline { 2 - 5 } & Males & Females & Males & Females \\
\hline 1- Believe there are no jobs & 38.9 & 47.7 & 43.1 & 49 \\
\hline 2- Tired of looking for jobs & 5.9 & 6 & 5.3 & 4.7 \\
\hline 3- Employers prefer hiring males to females & & 2.8 & & 3.5 \\
\hline 4- Do not know an effective way to look for a job & 7.6 & 6.6 & 8.7 & 8.2 \\
\hline 5- Waiting for M0MP hiring & 0 & 7.9 & 0 & 8.2 \\
\hline 6- No suitable job & 7.6 & 10.1 & 9.5 & 9.6 \\
\hline 7- Do not have enough training or education & 0.3 & 1.6 & 0.4 & 0 \\
\hline 8- Do not need work & 2 & 1.3 & 2.5 & 0.8 \\
\hline 9- Health conditions do not allow & 4.8 & 0 & 3.6 & 0 \\
\hline 10- Family responsibilities & 1.8 & 5.4 & 2.3 & 5.2 \\
\hline 11- Opposition of a family member & 0 & 1.8 & 0 & 1.9 \\
\hline 12- Lack of personal connections & 6.1 & 4.2 & 6.1 & 5.1 \\
\hline 13- Other & 24.9 & 4.4 & 18.4 & 4 \\
\hline Total & 100 & 100 & 100 & 100 \\
\hline
\end{tabular}

Chi-square sig. at 0.01 level.

Source: Author's calculations from Egyptian Labor Sample Survey 1998, and the Egypt Labor Market Panel Survey 2006.

Young females are the least active group in the job search. Main reasons behind not doing a job search among young unemployed females are similar to those among all females. However, they are relatively more pessimistic about availability of jobs in the labor market.

Lack of awareness about job search methods is higher among youth. This raises questions about the labor market institutions in Egypt, especially labor market intermediaries. The role of labor market intermediaries is not obvious for unemployed job searchers, especially among unemployed 
youth. Surprisingly, there is still a percentage of females waiting to be hired by the Ministry of Manpower. This percentage is even higher among female youth. There is an urgent need to support their job search through providing more information about other job search methods and how to use them and strengthening the role of labor market intermediaries.

\subsection{Job Search Intensity (1998-2006)}

Table (4) shows job search intensity among job searchers $\left(I_{I}=\mathrm{I}\right)$, for both genders. It shows job search intensity for all males and females and for both young males and females (15-29), taking into consideration registering in government employment office as one of the job search methods used.

Table (4): Job Search Intensity $\left(\mathrm{I}_{2}\right)$-with government-1998-2006

\begin{tabular}{|l|c|c|c|c|}
\hline & 1998 & 2006 & $\begin{array}{c}\text { Test } \\
\text { Significance }\end{array}$ & $2006 / 1998$ \\
\hline Male 15+ & 2.8671 & 4.1138 & 0.000 & 1.43 \\
\hline Female15+ & 2.3385 & 3.4173 & 0.000 & 1.46 \\
\hline Test significance & 0.000 & 0.000 & - & - \\
\hline $\begin{array}{l}\text { Male/female } \\
\text { relative gap }\end{array}$ & 1.23 & 1.20 & - & $(-)$ \\
\hline Total 15+ & 2.5839 & 3.7066 & 0.000 & 1.43 \\
\hline Male 15-29 & 2.7914 & 4.1337 & 0.000 & 1.48 \\
\hline Female 15-29 & 2.3084 & 3.3601 & 0.000 & 1.46 \\
\hline Test significance & 0.000 & 0.000 & - & - \\
\hline $\begin{array}{l}\text { Male/female } \\
\text { relative gap }\end{array}$ & 1.21 & 1.23 & - & $(+)$ \\
\hline Total 15-29 & 2.5271 & 3.6828 & 0.000 & 1.46 \\
\hline
\end{tabular}

Source: Author's calculations from Egyptian Labor Sample Survey 1998, and the Egypt Labor Market Panel Survey 2006.

The data illustrates that:

- Between 1998 and 2006, job search intensity increased significantly. This increase is obviously higher than the increase in job search propensity. The rate of increase in job search intensity among all the unemployed job searchers $\left(\mathrm{I}^{+}\right)$and the young unemployed job searchers ( $\left.15^{-29}\right)$ is I4 times and 23 times higher than the rate of increase in job search propensity.

- Unlike job search propensity, job search intensity increased for all groups. Unemployed job searchers $\left(\mathrm{I}_{\mathrm{I}}=\mathrm{I}\right)$, whether male or female, young or old, tend to exert more effort in the job search. Job search 
intensity increased at a higher rate among unemployed youth than among all the unemployed.

- While job search intensity for job searchers in 1998 ranges from one method to nine methods, the maximum number of methods used increased in 2006 by $33.3 \%$ to 12 methods.

- This is due to the transformation in the Egyptian labor market which forces job seekers to depend more on themselves in finding a job rather than depending on the government and public sectors. The unemployed are forced now to use more job search methods to find work. They should do more intense job searches to find work.

- However, this increase also hides gender differences in job search intensity.

- Unemployed male job searchers obviously do a more intense job search than unemployed female job searchers. Males' job search intensity is significantly higher than females' job search intensity in both 2006 and 1998.

- The gender gap in job search intensity is wider than the gap in job search propensity. The gap in job search intensity is around three times wider than the gap in search propensity among all the unemployed and also among unemployed youth. When unemployed males and females search for jobs, unemployed females are less active in their job search than males.

- The gender gap in search intensity is wider among youth than the job search propensity. Again, young females are the least active in the job search.

- Contrary to males, young females are less active than all females. Young women's search intensity is lower than the average job search intensity for women.

- Between 1998 and 2006, the gender gap in job search intensity decreased slightly. However, it increased slightly among unemployed youth.

Table (5) reports job search intensity for both male and female unemployed job searchers $\left(\mathrm{I}_{\mathrm{I}}=\mathrm{I}\right)$, excluding registering in government office from job search methods used.

Table (5): Job Search Intensity $\left(\mathrm{I}_{2}\right)$-without government-1998-2006

\begin{tabular}{|l|c|c|c|c|}
\hline & 1998 & 2006 & $\begin{array}{c}\text { Test } \\
\text { Significance }\end{array}$ & 2006/1998 \\
\hline Male 15+ & 2.5885 & 3.5799 & 0.000 & 1.38 \\
\hline Female 15+ & 1.9105 & 2.7690 & 0.000 & 1.45 \\
\hline Test significance & 0.000 & 0.000 & - & - \\
\hline
\end{tabular}




\begin{tabular}{|l|c|c|c|c|}
\hline $\begin{array}{l}\text { Male/female } \\
\text { relative gap }\end{array}$ & 1.35 & 1.21 & - & $(-)$ \\
\hline Total 15+ & 2.2252 & 3.1058 & 0.000 & 1.40 \\
\hline Male 15-29 & 2.5201 & 3.5830 & 0.000 & 1.42 \\
\hline Female 15-29 & 1.9100 & 2.7332 & 0.000 & 1.43 \\
\hline Test significance & 0.000 & 0.000 & - & - \\
\hline $\begin{array}{l}\text { Male/female } \\
\text { relative gap }\end{array}$ & 1.32 & 1.31 & - & $(-)$ \\
\hline Total 15-29 & 2.1862 & 3.0877 & 0.000 & 1.41 \\
\hline
\end{tabular}

Source: Author's calculations from Egyptian Labor Sample Survey 1998, and the Egypt Labor Market Panel Survey 2006.

Data in Table (5) shows that female unemployed job searchers do a less active job search compared with male unemployed job searchers if registering in government office is excluded from job search methods used:

- Job search intensity, excluding registering in government office, tended to increase at a relatively lower rate than job search intensity without excluding registering in government employment offices. It increased significantly among both unemployed male and female job searchers and young unemployed male and female job searchers.

- However, unemployed male job searchers are still more likely to search more intensively for work than unemployed female job searchers.

- The gender gap in job search intensity widens, excluding registering in government employment offices from job search methods used.

- The gender gap in job search intensity is wider among unemployed youth than among all the unemployed job searchers. While the rate of increase in job search intensity was higher among male youth than among all males, it was lower among female youth than among all females.

- However, the gender gap in job search intensity tended to decrease between 1998 and 2006, among all the unemployed job searchers. It was almost the same among unemployed youth.

- Depending on comparing job search intensity (excluding registering in government office) among males and females, we may reach the same conclusion that females are less active than males in job search, female youth are the least active. 


\subsection{Job Search Methods (1998-2006)}

\subsubsection{Patterns of job search and job finding}

Table (6): Job Search Methods Used-1998-2006

6-1:1998

\begin{tabular}{|l|c|c|c|c|c|c|}
\hline \multirow{2}{*}{ Methods } & \multicolumn{3}{|c|}{$15+$} & \multicolumn{3}{c|}{$15-29$} \\
\cline { 2 - 7 } & Male & Female & Total & Male & Female & Total \\
\hline 1- Registering in government office & 27.9 & 42.8 & 35.9 & 27.1 & 39.8 & 34.1 \\
\hline $\begin{array}{l}\text { 2- Registering in private } \\
\text { employment office }\end{array}$ & 11.1 & 7.2 & 9 & 10.2 & 7.5 & 8.7 \\
\hline $\begin{array}{l}\text { 3- Government job lottery } \\
\text { competition }\end{array}$ & 36.3 & 41.4 & 39.1 & 37.9 & 42.1 & 40.2 \\
\hline 4- Sending job application & 31 & 27.8 & 29.3 & 30.8 & 28.9 & 29.8 \\
\hline 5- Inquiring at work location & 38.6 & 14.9 & 25.9 & 37.6 & 13.3 & 24.3 \\
\hline 6- Advertising in newspapers & 1.8 & 1.2 & 1.5 & 2.2 & 1.4 & 1.7 \\
\hline $\begin{array}{l}\text { 7- Applying to an advertised job in } \\
\text { newspapers }\end{array}$ & 25.1 & 31.3 & 28.4 & 25.8 & 31.2 & 28.8 \\
\hline $\begin{array}{l}\text { 8- Asking friends or relatives for } \\
\text { help }\end{array}$ & 67.5 & 59.6 & 63.3 & 66.9 & 59.9 & 63.1 \\
\hline 9- Contacting employer & 24.5 & 5.8 & 14.5 & 20 & 5 & 11.8 \\
\hline 10- Contacting contractor & 13.7 & 0 & 6.4 & 11.9 & 0 & 5.4 \\
\hline 11- Waiting at a gathering location & 7.4 & 0 & 3.4 & 7 & 0 & 3.2 \\
\hline $\begin{array}{l}\text { 12- Searching for private project } \\
\text { (land-equipment) }\end{array}$ & 1 & 0.7 & 0.9 & 1.1 & 0.6 & 0.9 \\
\hline $\begin{array}{l}\text { 13- Arranging to get financing for a } \\
\text { private project }\end{array}$ & 0.8 & 1 & 0.9 & 0.5 & 1 & 0.8 \\
\hline 14- - ther & 0 & 0 & 0 & 0 & 0 & 0 \\
\hline
\end{tabular}

\section{6-2: 2006}

\begin{tabular}{|l|c|c|c|c|c|c|}
\hline \multirow{2}{*}{ Methods } & \multicolumn{3}{|c|}{$>=15$} & \multicolumn{3}{c|}{$15-29$} \\
\cline { 2 - 8 } & Male & Female & Total & Male & Female & Total \\
\hline 1- Registering in government office & 53.4 & 64.8 & 60.1 & 55.1 & 62.7 & 59.5 \\
\hline $\begin{array}{l}\text { 2- Registering in private } \\
\text { employment office }\end{array}$ & 29 & 24.9 & 26.6 & 30 & 24.7 & 26.9 \\
\hline $\begin{array}{l}\text { 3- Government job lottery } \\
\text { competition }\end{array}$ & 46.5 & 54.4 & 51.1 & 48.5 & 53.8 & 51.6 \\
\hline 4- Sending job application & 53 & 54.6 & 53.9 & 54.9 & 53.3 & 54 \\
\hline 5- Inquiring at work location & 40.8 & 21.4 & 29.4 & 41.3 & 22.2 & 30.1 \\
\hline
\end{tabular}




\begin{tabular}{|l|c|c|c|c|c|c|}
\hline 6- Advertising in newspapers & 6.1 & 5.7 & 5.8 & 6.5 & 5.9 & 6.2 \\
\hline $\begin{array}{l}\text { 7- Applying to an advertised job in } \\
\text { newspapers }\end{array}$ & 36.8 & 31.3 & 33.6 & 37.1 & 30.3 & 33.1 \\
\hline 8- Asking friends or relatives for help & 72.5 & 62.8 & 66.8 & 73.4 & 63.4 & 67.5 \\
\hline 9- Contacting employer & 42.6 & 17.8 & 28.1 & 39.5 & 16.9 & 26.3 \\
\hline 10- Contacting contractor & 14.2 & 1.3 & 6.7 & 13.1 & 1.4 & 6.3 \\
\hline 11- Waiting at a gathering location & 9 & 0.9 & 4.3 & 7.8 & 0.7 & 3.7 \\
\hline $\begin{array}{l}\text { 12- Searching for private project } \\
\text { (land-equipment) }\end{array}$ & 4.5 & 1.2 & 2.6 & 3.6 & 0.4 & 1.7 \\
\hline $\begin{array}{l}\text { 13- Arranging to get financing for a } \\
\text { private project }\end{array}$ & 2.5 & 0.6 & 1.4 & 2 & 0.4 & 1 \\
\hline 14- Other & 0.7 & 0 & 0.3 & 0.8 & 0 & 0.3 \\
\hline
\end{tabular}

Chi-square sig. at 0.01 level.

Source: Author's calculations from Egyptian Labor Sample Survey 1998, and the Egypt Labor Market Panel Survey 2006.

Table (6) shows propensity to use different job search methods among both male and female unemployed searchers $\left(\mathrm{I}_{\mathrm{I}}=\mathrm{I}\right)$ in $\mathrm{I} 998$ and 2006.

The most important job search method used in Egypt in both 1998 and 2006 for both male and female unemployed job searchers is the informal search methods; finding job through the help of friends and relatives.

The second most important job search method used by the unemployed is registering in government office. Females depend on this method more than males. It is used by unemployed youth more than by all the unemployed job searchers. Government job competitions are also a very popular method for job search, especially among females.

The importance of these methods, especially the second one, has actually increased between 1998 and 2006.

\section{This reflects a major labor market distortion in Egypt. This distortion is three-dimensional:}

a) The unemployed, even among youth, still depend on registering in government employment offices to find a job in spite of the fact that it is well known that the public sector employment guarantee came to an end more than two decades ago. Job seekers, especially unemployed youth, know that they cannot anymore depend on the public sector employment guarantee. In spite of the fact that this transformation in the labor market was expected to result in less dependency on registering in government employment offices as a job search method, the importance of this method is increasing. Moreover, around $3 / 4$ of both all the unemployed and unemployed youth; $73.7 \%$ and $73.1 \%$ respectively, who used this method registered in the Ministry of Manpower, only one fourth of them registered with the Ministry of Administrative Development in 2006. 
b) Informal methods are still the predominant job search methods used. The unemployed depend on this method as the major job search method. Finding a job depends thus not on qualifications but on social networks. This would negatively affect incentives to acquire skills, which in turn negatively affect the quality of human capital and productivity.

c) Formal search methods other than registering in the government depend mainly on contacting employers directly; through competitions, sending job applications, and applying to an advertised job in newspapers. Sending job applications is used more by females than by males. On the other hand, other search methods that entail direct contact with employers include contacting the employer or contractor, inquiring at work, and waiting in a gathering location are methods mainly used by males. They are not suitable for females. Nongovernmental labor market intermediaries still play a small role in the Egyptian labor market in spite of the fact that this role has increased between 1998 and 2006. Transforming to a market economy where the private sector plays the leading role in providing employment where job seekers should conduct an intense job search has not been accompanied with the necessary transformation in labor market institutions. Again, there is a need to strengthen the role of private formal labor market intermediaries in the Egyptian labor market. The propensity to register in a private employment office has risen between 1998 and 2006; however it is still mainly concentrated among the higher educated (post-secondary) while more than $60 \%$ of unemployed job searchers have only obtained secondary education or less. The propensity to use this method is very low; lower than average, among the majority of unemployed job seekers. It is lower among females. The work of these offices should be organized and then promoted among job seekers especially among unemployed youth.

Table (7): Propensity to Register in a Private Employment Office among Unemployed Job Seekers 2006 by Educational Level

\begin{tabular}{|l|c|c|}
\hline Educational Level & $15+$ & $15-29$ \\
\hline No school certificate & 5.6 & 10.4 \\
\hline Basic education & 10.8 & 9.7 \\
\hline Secondary education & 24.6 & 24.5 \\
\hline Post-secondary education & 32.8 & 32.2 \\
\hline Total & 26.6 & 26.5 \\
\hline
\end{tabular}

Chi-square sig. at 0.01 level.

Source: Author's calculations from the Egypt Labor Market Panel Survey 2006. 
It is worth mentioning that in spite of all governmental and nongovernmental efforts to promote entrepreneurship especially among youth, establishing a private project as a method to escape unemployment is still very limited, especially among females. The propensity to search for private projects and to get financing for a private project is only $1.7 \%$ and $\mathrm{I} \%$ respectively among all unemployed youth in 2006 compared to $0.9 \%$ and $0.8 \%$ in 1998 . It decreases to only $0.4 \%$ and $0.4 \%$ among female unemployed youth in 2006 comparing to $0.6 \%$ and $1 \%$. Propensity to establish a private project tended to decrease among female unemployed youth. This raises the questions about the effectiveness of these efforts especially in addressing female youth and also about the suitability of the investment climate in Egypt for MSMEs ${ }^{4}$.

Job search methods may be classified into three groups:

Figure 3: Job Search Methods

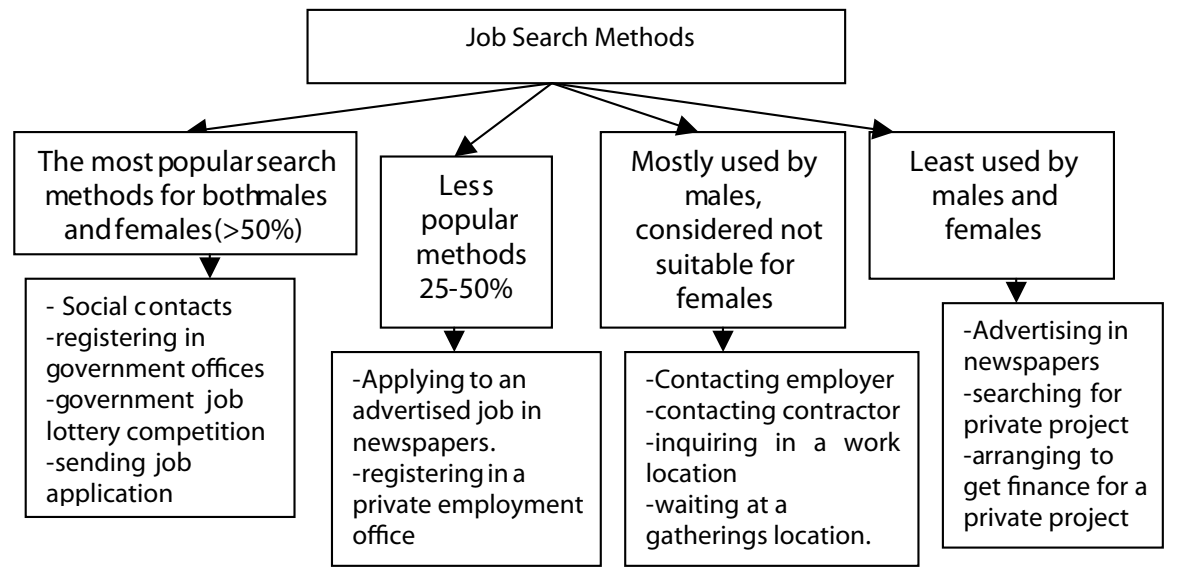

Actually this labor market distortion and this pattern of job search reflect on the predominant job finding methods (Table 8).

Table (8): The Importance of Different Job Finding Methods* 2006

\begin{tabular}{|l|c|c|c|c|c|c|}
\hline \multirow{2}{*}{ Methods } & \multicolumn{3}{|c|}{$15+$} & \multicolumn{3}{c|}{$15-29$} \\
\cline { 2 - 8 } & Male & Female & Total & Male & Female & Total \\
\hline 1- Registering in government office & 0.15 & 0.34 & 0.18 & 0.03 & 0.14 & 0.05 \\
\hline 2-Registering in private employment office & 0.01 & 0.01 & 0.01 & 0.01 & 0.01 & 0.01 \\
\hline 3-Government job lottery competition & 0.15 & 0.23 & 0.16 & 0.06 & 0.15 & 0.08 \\
\hline 4- Sending job applications & 0.19 & 0.25 & 0.20 & 0.12 & 0.23 & 0.14 \\
\hline 5- Inquiring at work locations & 0.10 & 0.07 & 0.09 & 0.11 & 0.08 & 0.10 \\
\hline 6- Advertising in newspapers & 0.01 & 0.01 & 0.01 & 0.002 & 0.01 & 0.00 \\
\hline
\end{tabular}

4 Micro, small and medium sized enterprises. 


\begin{tabular}{|l|c|c|c|c|c|c|}
\hline $\begin{array}{l}\text { 7-Applying to an advertised job in } \\
\text { newspapers }\end{array}$ & 0.03 & 0.06 & 0.03 & 0.02 & 0.07 & 0.03 \\
\hline 8- Asking friends or relatives for help & 0.42 & 0.32 & 0.40 & 0.51 & 0.47 & 0.5 \\
\hline 9- Contacting employer & 0.27 & 0.14 & 0.25 & 0.38 & 0.25 & 0.35 \\
\hline 10- Contacting contractor & 0.08 & 0.02 & 0.07 & 0.12 & 0.03 & 0.11 \\
\hline 11- Waiting at a gathering location & 0.06 & 0.003 & 0.05 & 0.09 & 0 & 0.07 \\
\hline $\begin{array}{l}\text { 12-Searching for private project (land- } \\
\text { equipment) }\end{array}$ & 0 & 0 & 0 & 0 & 0 & 0 \\
\hline $\begin{array}{l}\text { 13-Arranging to get finance for a private } \\
\text { project }\end{array}$ & 0 & 0 & 0 & 0 & 0 & 0 \\
\hline 14- -ther & 0.04 & 0.05 & 0.04 & 0.05 & 0.05 & 0.05 \\
\hline
\end{tabular}

${ }^{*} A$ constructed index to measure the importance of this method as a job finding method = (percentage of those who are currently working and reported this method as the main job finding method $\times 2+$ percentage of those who are currently working and reported this method as the secondary job finding method $\times 1$ ) / 2 .

Source: Author's calculations from the Egypt Labor Market Panel Survey 2006.

Table (8) illustrates that the most important job finding methods are informal methods and finding jobs through social contacts, friends, and relatives. These informal methods are the most important search method for both males and females (Table 6 and Figure 3). Four of the most important five job finding methods are the most important job search methods (Figure 3). One of the five most important job finding methods is "contacting employer" which is more important for males than for females; the same result applies to job search methods (Figure 3). On the other hand, registering in a government employment office and government job lottery competitions is more important for females than for males (Table 8).

Registering in government employment offices has been far less important as a job finding method for youth workers than among all workers. However, it is still the third most important job search method for unemployed youth. This asserts the previously mentioned labor market distortion.

\subsubsection{Formal job search}

Table (9) reports propensity to use a formal job search method among all male and female unemployed job searchers and among unemployed youth $\left(\mathrm{I}_{\mathrm{r}}=\mathrm{I}\right)$ in 1998 and 2006.

Table (9): Propensity to Use a Formal Job Search Method 1998-2006

\begin{tabular}{|l|c|c|c|c|}
\hline & 1998 & 2006 & $\begin{array}{c}\text { Test } \\
\text { Significance }\end{array}$ & 2006/1998 \\
\hline Male 15+ & 0.8861 & 0.9571 & 0.000 & 1.08 \\
\hline Female15+ & 0.8782 & 0.9381 & 0.000 & 1.07 \\
\hline
\end{tabular}

continued 


\begin{tabular}{|l|c|c|c|c|}
\hline Test significance & 0.000 & 0.000 & - & - \\
\hline $\begin{array}{l}\text { Male/female relative } \\
\text { gap }\end{array}$ & 1.01 & 1.02 & - & $(+)$ \\
\hline Total 15+ & 0.8819 & 0.9460 & 0.000 & 1.07 \\
\hline Male 15-29 & 0.8790 & 0.9551 & 0.000 & 1.09 \\
\hline Female 15-29 & 0.8747 & 0.9327 & 0.000 & 1.07 \\
\hline Test significance & 0.000 & 0.000 & - & - \\
\hline $\begin{array}{l}\text { Male/female relative } \\
\text { gap }\end{array}$ & 1.01 & 1.02 & - & $(+)$ \\
\hline Total 15-29 & 0.8767 & 0.9420 & 0.000 & 1.07 \\
\hline
\end{tabular}

Source: Author's calculations from Egyptian Labor Sample Survey 1998, and the Egypt Labor Market Panel Survey 2006.

The propensity to use a formal method tended to increase between 1998 and 2006, among all the unemployed job searchers and among unemployed youth job searchers. This increase is the result of the increase in both job search propensity and intensity. This is due to the increasing need of doing an intense job search as the result of transformation in the Egyptian labor market.

Women's propensity to use a formal search method is less than that of men. However, the gap is relatively small, among all the unemployed and the unemployed youth job searchers. The propensity to use a formal method is lowest among female youth.

One of the most important job search methods is registering in a government employment office. Table (IO) illustrates the propensity to use a formal job search method excluding registering in a government employment office, among unemployed job searchers $\left(\mathrm{I}_{\mathrm{I}}=\mathrm{I}\right)$.

Table (10): Propensity to Use a Formal Method Excluding registering in a government employment office 1998-2006

\begin{tabular}{|l|c|c|c|c|}
\hline & 1998 & 2006 & $\begin{array}{c}\text { Test } \\
\text { Significance }\end{array}$ & 2006/1998 \\
\hline Male 15+ & 0.8338 & 0.9129 & 0.000 & 1.09 \\
\hline Female15+ & 0.7082 & 0.8189 & 0.000 & 1.16 \\
\hline Test significance & 0.000 & 0.000 & - & - \\
\hline Male/female relative gap & 1.18 & 1.11 & - & $(-)$ \\
\hline Total 15+ & 0.7665 & 0.8579 & 0.000 & 1.12 \\
\hline Male 15-29 & 0.8277 & 0.9065 & 0.000 & 1.10 \\
\hline Female 15-29 & 0.7194 & 0.8201 & 0.000 & 1.14 \\
\hline Test significance & 0.000 & 0.000 & - & - \\
\hline Male/female relative gap & 1.15 & 1.11 & - & $(-)$ \\
\hline Total 15-29 & 0.7684 & 0.8561 & 0.000 & 1.11 \\
\hline
\end{tabular}

Source: Author's calculations from Egyptian Labor Sample Survey 1998, and the Egypt Labor Market Panel Survey 2006. 
The propensity to use a formal method excluding registering in a government employment office increased between 1998 and 2006, among all the unemployed, including youth job searchers. It increases at a rate higher than the rate of increase in the propensity to use a formal method including registering in a government employment office (Table 9).

The gender gap in the propensity to use a formal job search method, excluding registering in a government employment office, decreased.

However, it is worth mentioning that the gender gap is obviously larger in using a formal job search method, excluding registering in a government employment office, than in using a formal job search method including registering in a government employment office. The propensity to use a formal job search method decreases among all unemployed, and among young unemployed women sharply decreases to 0.87 and 0.88 times the propensity to use a formal method including registering in a government employment office, while it decreases among men to only 0.95 and 0.94 . Females are still more dependent than males on the government in their job search.

Table (11): Propensity to Use Formal Methods only 1998-2006

\begin{tabular}{|l|c|c|c|c|}
\hline & 1998 & 2006 & $\begin{array}{c}\text { Test } \\
\text { Significance }\end{array}$ & 2006/1998 \\
\hline Male 15+ & 0.3247 & 0.2755 & 0.000 & 0.85 \\
\hline Female15+ & 0.4035 & 0.3720 & 0.000 & 0.92 \\
\hline Test significance & 0.000 & 0.000 & - & - \\
\hline Male/female relative gap & 0.80 & 0.74 & - & $+^{*}$ \\
\hline Total 15+ & 0.3669 & 0.3319 & 0.000 & 0.90 \\
\hline Male 15-29 & 0.3308 & 0.2665 & 0.000 & 0.81 \\
\hline Female 15-29 & 0.4010 & 0.3661 & 0.000 & 0.91 \\
\hline Test significance & 0.000 & 0.000 & - & - \\
\hline Male/female relative gap & 0.82 & 0.73 & - & + \\
\hline Total 15-29 & 0.3692 & 0.3245 & 0.000 & 0.88 \\
\hline
\end{tabular}

* The relative gap decreases when it is closer to 1 .

Source: Author's calculations from Egyptian Labor Sample Survey 1998, and the Egypt Labor Market Panel Survey 2006.

All unemployed females and youth unemployed females are also more likely to depend on using only formal methods than males (Table II). The gender gap in depending only on formal job search methods has been widening between 1998 and 2006 , indicating that females are becoming less active in job search comparing to males. 
Moreover, around one tenth of unemployed female job searchers depend only on registering in a government employment office for their job search (Table I2). The propensity to depend only on registering in a government employment office among females is almost three times higher than the propensity among males. The gender gap in depending on registering in a government employment office as a sole job search method decreased between 1998 and 2006 . However, it is still a wide gap.

Table (12): Propensity to depend only on registering in a government employment office 1998-2006

\begin{tabular}{|l|c|c|c|c|}
\hline & 1998 & 2006 & $\begin{array}{c}\text { Test } \\
\text { Significance }\end{array}$ & 2006/1998 \\
\hline Male 15+ & 0.0265 & 0.0356 & 0.000 & 1.3 \\
\hline Female15+ & 0.1077 & 0.0914 & 0.000 & 0.85 \\
\hline Test significance & 0.000 & 0.000 & - & - \\
\hline Male/female relative gap & 0.25 & 0.39 & - & $(-)^{*}$ \\
\hline Total 15+ & 0.0700 & 0.0682 & 0.000 & 0.97 \\
\hline Male 15-29 & 0.0197 & 0.0383 & 0.000 & 1.94 \\
\hline Female 15-29 & 0.0967 & 0.0804 & 0.000 & 0.83 \\
\hline Test significance & 0.000 & 0.000 & - & - \\
\hline Male/female relative gap & 0.20 & 0.48 & - & $(-)$ \\
\hline Total 15-29 & 0.0619 & 0.0628 & 0.000 & 1.01 \\
\hline
\end{tabular}

* The relative gap decreases when it gets closer to 1 .

Source: Author's calculations from Egyptian Labor Sample Survey 1998, and the Egypt Labor Market Panel Survey 2006.

However, depending only on formal methods or on registering in a government employment office has decreased among the unemployed job searchers $\left(15^{+}\right)$. This decrease indicates the increasing need to be more active in the job search in the Egyptian labor market.

\subsubsection{Informal job search}

Informal job search methods were the most important methods in both 1998 and 2006 among both males and females. Table (I3) illustrates the informal job search among unemployed job searchers $\left(\mathrm{I}_{\mathrm{I}}=\mathrm{I}\right)$ in 1998 and 2006.

Table (13): Propensity to use an informal method 1998-2006

\begin{tabular}{|l|c|c|c|c|}
\hline & 1998 & 2006 & $\begin{array}{c}\text { Test } \\
\text { Significance }\end{array}$ & $2006 / 1998$ \\
\hline Male 15+ & 0.6753 & 0.7245 & 0.000 & 1.07 \\
\hline Female15+ & 0.5965 & 0.6280 & 0.000 & 1.05 \\
\hline
\end{tabular}




\begin{tabular}{|l|c|c|c|c|}
\hline Test significance & 0.000 & 0.000 & - & - \\
\hline Male/female relative gap & 1.13 & 1.15 & - & $(+)$ \\
\hline Total 15+ & 0.6331 & 0.6681 & 0.000 & 1.06 \\
\hline Male 15-29 & 0.6692 & 0.7335 & 0.000 & 1.09 \\
\hline Female 15-29 & 0.5990 & 0.6339 & 0.000 & 1.06 \\
\hline Test significance & 0.000 & 0.000 & - & - \\
\hline Male/female relative gap & 1.12 & 1.16 & - & $(+)$ \\
\hline Total 15-29 & 0.6308 & 0.6755 & 0.000 & 1.07 \\
\hline
\end{tabular}

Source: Author's calculations from Egyptian Labor Sample Survey 1998, and the Egypt Labor Market Panel Survey 2006.

Using informal job search methods increased between 1998 and 2006 , among both males and females. The rate of increase is slightly higher among the unemployed youth than among all of the unemployed. It is also higher among males than among females.

Males are more likely to use informal job search methods than females. While the same result applies to formal job search methods, it is obvious that the gender gap is wider in the case of using informal job search methods (Tables IO, I3). This result applies to both all the unemployed and the unemployed youth. The gender gap in propensity to use an informal job search increased between 1998 and 2006.

In spite of the fact that informal job search methods are the most important job search methods used in the Egyptian labor market, only a very small percentage of the unemployed job searchers may depend only on these methods. In addition, depending only on informal methods have decreased sharply between 1998 and 2006, indicating a more active job search; as unemployed job searchers use different types of search methods. In the Egyptian labor market, using social contacts is very important but that does not lead to depending only on it. Using social contacts and formal methods are considered complements rather than substitutes.

Again, females are less active in the job search; they may depend on one type of search. They are more likely than males to depend only on informal methods in spite of the fact that they are less likely than males to use informal search methods generally (Tables I3, I4).

Table (14): Propensity to use an informal method only 1998-2006

\begin{tabular}{|l|c|c|c|c|}
\hline & 1998 & 2006 & $\begin{array}{c}\text { Test } \\
\text { Significance }\end{array}$ & $2006 / 1998$ \\
\hline Male 15+ & 0.1139 & 0.0429 & 0.000 & 0.38 \\
\hline Female15+ & 0.1218 & 0.0619 & 0.000 & 0.51 \\
\hline Test significance & 0.000 & 0.000 & - & - \\
\hline
\end{tabular}




\begin{tabular}{|l|c|c|c|c|}
\hline Male/female relative gap & 0.94 & 0.69 & - & $(+)^{*}$ \\
\hline Total 15+ & 0.1181 & 0.0540 & 0.000 & 0.46 \\
\hline Male 15-29 & 0.1210 & 0.0449 & 0.000 & 0.37 \\
\hline Female 15-29 & 0.1253 & 0.0673 & 0.000 & 0.54 \\
\hline Test significance & 0.000 & 0.000 & - & - \\
\hline Male/female relative gap & 0.97 & 0.67 & - & $(+)$ \\
\hline Total 15-29 & 0.1233 & 0.0580 & 0.000 & 0.47 \\
\hline
\end{tabular}

* The relative gap decrease when it gets closer to 1 .

Source: Author's calculations from Egyptian Labor Sample Survey 1998, and the Egypt Labor Market Panel Survey 2006.

\subsubsection{The formal and informal job search}

Using different types of job search methods indicates an active job search. I ranges from $O$ to 2 ; where $O$ indicates not using neither formal nor informal job search, I indicates using either formal or informal job search methods, and 2 indicates using both formal and informal job search methods.

Table ( ${ }_{5}$ ) illustrates $I_{3}$ for all the unemployed and unemployed youth, for both males and females in 1998 and 2006. Table ( $15^{-}-\mathrm{I}$ ) shows $\mathrm{I}_{3}$ if registering in a government employment office is considered while table $\left(5^{-2}\right)$ shows $\mathrm{I}_{3}$ excluding registering in a government employment office from job search methods used.

Table (15): Using formal and informal methods $\left(I_{3}\right)-1998-2006$

15-1: Using formal and informal methods (13)-with government-1998-2006

\begin{tabular}{|l|c|c|c|c|}
\hline & 1998 & 2006 & $\begin{array}{c}\text { Test } \\
\text { Significance }\end{array}$ & $2006 / 1998$ \\
\hline Male 15+ & 1.5614 & 1.6816 & 0.000 & 1.08 \\
\hline Female15+ & 1.4747 & 1.5661 & 0.000 & 1.06 \\
\hline Test significance & 0.000 & 0.000 & - & - \\
\hline Male/female relative gap & 1.06 & 1.07 & - & $(+)$ \\
\hline Total 15+ & 1.5149 & 1.6141 & 0.000 & 1.07 \\
\hline Male 15-29 & 1.5482 & 1.6887 & 0.000 & 1.09 \\
\hline Female 15-29 & 1.4737 & 1.5666 & 0.000 & 1.06 \\
\hline Test significance & 0.000 & 0.000 & - & - \\
\hline Male/female relative gap & 1.05 & 1.08 & - & $(+)$ \\
\hline Total 15-29 & 1.5075 & 1.6175 & 0.000 & 1.07 \\
\hline
\end{tabular}


15-2: Using formal and informal methods (|3)-without government 1998-2006

\begin{tabular}{|l|c|c|c|c|}
\hline & 1998 & 2006 & $\begin{array}{c}\text { Test } \\
\text { Significance }\end{array}$ & 2006/1998 \\
\hline Male 15+ & 1.5090 & 1.6374 & 0.000 & 1.09 \\
\hline Female15+ & 1.3047 & 1.4469 & 0.000 & 1.11 \\
\hline Test significance & 0.000 & 0.000 & - & - \\
\hline Male/female relative gap & 1.16 & 1.13 & - & $(-)$ \\
\hline Total 15+ & 1.3996 & 1.5260 & 0.000 & 1.09 \\
\hline Male 15-29 & 1.4969 & 1.6400 & 0.000 & 1.10 \\
\hline Female 15-29 & 1.3184 & 1.4540 & 0.000 & 1.10 \\
\hline Test significance & 0.000 & 0.000 & - & - \\
\hline Male/female relative gap & 1.14 & 1.13 & - & $(-)$ \\
\hline Total 15-29 & 1.3992 & 1.5316 & 0.000 & 1.10 \\
\hline
\end{tabular}

Source: Author's calculations from Egyptian Labor Sample Survey 1998, and the Egypt Labor Market Panel Survey 2006.

The propensity to use both formal and informal job search methods has increased significantly between 1998 and 2006, indicating a more active job search for the unemployed in the Egyptian labor market. This result applies to both $\mathrm{I}_{3}$ including government registration and $\mathrm{I}_{3}$ excluding government registration, among males and females, and among all unemployed and the unemployed youth. The rate of increase in $\mathrm{I}_{3}$ without government registration is higher than in $\mathrm{I}_{3}$ with government registration.

The propensity to use both formal and informal job search methods is significantly higher among males than among females. The gender gap is wider if registering in a government employment office is excluded from job search methods used. Females are less active than males, especially if we exclude registering in a government employment office from job search methods used. $\mathrm{I}_{3}$ is slightly higher among unemployed youth than among all the unemployed.

\subsection{Job Search Efficiency Index 1 (JSE1) (1998-2006)}

Job search efficiency Indexi is a composite index that measures the efficiency of job search behavior. It is constructed using the three previously mentioned job search measures. Table (I6) illustrates JSEI for all the unemployed and unemployed youth, for both males and females in 1998 and 2006. Table (I6-I) reports JSEI if registering in a government employment office is included in job search methods used, while table $\left(\mathrm{I}^{-}-2\right)$ reports JSEI if registering in a government employment office is excluded from job search methods used. 
Table (16): Job Search Efficiency Index1 (JSE1)-1998-2006

16-1: Job Search Efficiency Index1 (JSE1)-with government-1998-2006

\begin{tabular}{|l|c|c|c|c|}
\hline & 1998 & 2006 & $\begin{array}{c}\text { Test } \\
\text { Significance }\end{array}$ & $2006 / 1998$ \\
\hline Male 15+ & 0.4500 & 0.5242 & 0.000 & 1.16 \\
\hline Female15+ & 0.4159 & 0.4454 & 0.000 & 1.07 \\
\hline Test significance & 0.000 & 0.000 & - & - \\
\hline Male/female relative gap & 1.08 & 1.18 & - & $(+)$ \\
\hline Total 15+ & 0.4319 & 0.4770 & 0.000 & 1.10 \\
\hline Male 15-29 & 0.4585 & 0.5309 & 0.000 & 1.16 \\
\hline Female 15-29 & 0.4163 & 0.4407 & 0.000 & 1.06 \\
\hline Test significance & 0.000 & 0.000 & - & - \\
\hline Male/female relative gap & 1.10 & 1.20 & - & + \\
\hline Total 15-29 & 0.4353 & 0.4767 & 0.000 & 1.10 \\
\hline
\end{tabular}

16-2: Job Search Efficiency Index1 (JSE1)-without government-1998-2006

\begin{tabular}{|l|c|c|c|c|}
\hline & 1998 & 2006 & $\begin{array}{c}\text { Test } \\
\text { Significance }\end{array}$ & 2006/1998 \\
\hline Male 15+ & 0.4266 & 0.5068 & 0.000 & 1.19 \\
\hline Female15+ & 0.3606 & 0.4067 & 0.000 & 1.13 \\
\hline Test significance & 0.000 & 0.000 & - & - \\
\hline Male/female relative gap & 1.18 & 1.25 & - & + \\
\hline Total 15+ & 0.3915 & 0.4468 & 0.000 & 1.14 \\
\hline Male 15-29 & 0.4349 & 0.5117 & 0.000 & 1.18 \\
\hline Female 15-29 & 0.3652 & 0.4043 & 0.000 & 1.11 \\
\hline Test significance & 0.000 & 0.000 & - & - \\
\hline Male/female relative gap & 1.19 & 1.27 & - & + \\
\hline Total 15-29 & 0.3966 & 0.4472 & 0.000 & 1.13 \\
\hline
\end{tabular}

Source: Author's calculations from Egyptian Labor Sample Survey 1998, and the Egypt Labor Market Panel Survey 2006.

Job search efficiency Indexi (JSEI) has increased significantly between 1998 and 2006, among all the unemployed and unemployed youth, among males and females. This trend indicates that the unemployed job search in the Egyptian labor market is getting to be more active. This is one of the most important results of the transformation in the Egyptian economy as a whole and specifically in the Egyptian labor market, toward a market dominated by the private sector and toward a more limited role for the government and public sectors in providing employment. 
It is worth mentioning that the rate of increase in JSEI is higher if registering in a government employment office is excluded from job search methods used. Although this method is still the second most important job search method used in the Egyptian labor market (Table 6), depending solely on it has decreased (Table I2), the unemployed tend to use several diverse methods (Table 15), rather than depending on registration in government employment offices only. This is actually a good sign toward eliminating the previously mentioned three-dimensional labor market distortion.

However, a comparison of JSEI for males and females reveals four alarming facts that raise worries about women's position in the Egyptian labor market and also about their future labor market outcomes. These four facts are:

- Using either JSEI with government registration or JSEI without government registration, it is found that females are less active in the job search than males in 1998 and in 2006.

- Moreover, the gender gap in JSEr has widened between 1998 and 2006.

- This gender gap is wider among youth unemployed than among all the unemployed.

- It is even wider excluding registration in government employment offices from job search methods used. Females are not only less active in the job search, but they are also still more dependent on the government to find work.

\subsection{Job Search Efficiency Index 2 (JSE2)-2006}

Job Search Efficiency Index 2 (JSE2) is a composite index that measures the efficiency of job search behavior considering using new methods as complementary to traditional ones. It is constructed for 2006 only as ELMPSo6 questionnaire entails questions on using new methods as complementary to traditional job search methods while ELMS98 does not.

\subsubsection{Using new job search methods}

Table ( 17 ) reports propensity to use different information and communication technologies (ICTs) in the job search as complementary to traditional job search methods. $\mathrm{ST}_{1}, \mathrm{ST}_{2}, \mathrm{ST}_{3}$ indicates the propensity to use regular phone, cell phone, and computer in job search, ST is a composite index that measures intensity of using ICTs in job search, it ranges from $\mathrm{o}$ indicating no use to 3 indicating using the three previously mentioned methods. 
Table (17): Using new methods as supplementary to traditional job search methods 2006

\begin{tabular}{|l|c|c|c|c|}
\hline & $\begin{array}{c}\text { ST1 } \\
(\mathbf{0}-1)\end{array}$ & $\begin{array}{c}\text { ST2 } \\
(\mathbf{0}-1)\end{array}$ & $\begin{array}{c}\text { ST3 } \\
(\mathbf{0}-1)\end{array}$ & $\begin{array}{c}\text { ST } \\
(\mathbf{0}-3)\end{array}$ \\
\hline Male 15+ & 0.4549 & 0.1417 & 0.2247 & 0.8213 \\
\hline Female15+ & 0.3479 & 0.0526 & 0.1599 & 0.5604 \\
\hline Test significance & 0.000 & 0.000 & 0.000 & 0.000 \\
\hline Male/female relative gap & 1.31 & 2.7 & 1.41 & 1.47 \\
\hline Total 15+ & 0.394 & 0.091 & 0.188 & 0.67 \\
\hline Male 15-29 & 0.4418 & 0.1241 & 0.2225 & 0.7884 \\
\hline Female 15-29 & 0.3428 & 0.0541 & 0.1692 & 0.5661 \\
\hline Test significance & 0.000 & 0.000 & 0.000 & 0.000 \\
\hline Male/female relative gap & 1.29 & 2.3 & 1.32 & 1.40 \\
\hline Total 15-29 & 0.385 & 0.084 & 0.192 & 0.66 \\
\hline
\end{tabular}

Source: Author's calculations from the Egypt Labor Market Panel Survey 2006.

Using new methods complementary to the traditional job search methods is still limited among the unemployed job searchers in the Egyptian labor market. Less than one fifth of the unemployed job searchers use the computer in their search. The average value of ST that measures the intensity of using these new methods is less than I; it is around one fifth of the maximum value it may reach. It is actually the same among all the unemployed and the unemployed youth.

The use of new search methods by women is significantly lower than the use of these methods by men. This result applies to all the unemployed including the unemployed youth.

It may be suggested that differences in the educational level is behind these differences. However, analyzing educational differences between male and female unemployed job searchers reveals that these differences are actually in favor of females (Table i8).

Table 18: Educational level of the unemployed job searchers \%

\begin{tabular}{|l|c|c|c|c|}
\hline \multirow{2}{*}{} & \multicolumn{2}{|c|}{$15+$} & \multicolumn{2}{c|}{$15-29$} \\
\cline { 2 - 5 } & Males & Females & Males & Females \\
\hline No school certificate & 7.4 & 0.6 & 4.9 & 0.3 \\
\hline Basic education & 7.2 & 1.6 & 5.5 & 1.4 \\
\hline Secondary education & 45.7 & 59 & 48.4 & 57.3 \\
\hline Post secondary education and above & 39.7 & 38.8 & 41.2 & 41 \\
\hline
\end{tabular}

Chi-square sig. at 0.01 level.

Source: Author's calculations from the Egypt Labor Market Panel Survey 2006. 
The lack of trust by women in these new methods specifically and in all non-governmental search methods generally in addition to their high dependency on the government in their job search may explain gender differences in using these new methods, especially if we consider that the use of these methods is still not organized by law.

Focusing on one important new search method, which is Internet job search that is increasingly spreading in different economies as previously mentioned, Table (ig) illustrates that using an Internet job search is very limited in the Egyptian labor market among all the unemployed including the unemployed youth. Only around $5 \%$ of the unemployed job searchers in Egypt are using the Internet in their job search.

The limited use of an Internet job search by unemployed job searchers is not split from the limited use of this method by employers in Egypt as a hiring method.

Table 19: Using Internet Job Search $2006 \%$

\begin{tabular}{|c|c|c|c|}
\hline Using Computer in Job Search & Male & Female & Total \\
\hline \multicolumn{4}{|c|}{$15+$} \\
\hline Using Internet & 8.6 & 2.8 & 5.3 \\
\hline Computer, no Internet & 13.9 & 13.2 & 13.5 \\
\hline None & 77.5 & 84 & 81.2 \\
\hline \multicolumn{4}{|c|}{$15-29$} \\
\hline Using Internet & 8.4 & 2.7 & 5.2 \\
\hline Computer, no Internet & 13.8 & 14.2 & 14 \\
\hline None & 77.7 & 83.1 & 80.8 \\
\hline
\end{tabular}

Source: Author's calculations from the Egypt Labor Market Panel Survey 2006.

Comparing male and female Internet job search, it is obvious that the propensity to use the Internet in the job search is significantly higher among males than among females. The gender gap is far wider than the gender gap in using traditional job search methods. Male propensity to use the Internet is three times higher than that of women. This result applies to unemployed job searchers of all ages.

Thus, re-estimating $\mathrm{I}_{3}$-with and without registration in a government office-after considering using new job search methods as complementary to traditional job search methods 5 , the gender gap in $\mathrm{I}_{3}$ widens.

5 Refer to equation (4). 
Table (20): Using formal and informal methods (I3) Considering using new job search methods-1998-2006

\begin{tabular}{|l|c|c|}
\hline & $\begin{array}{c}\text { I3- with government } \\
\text { registration } \\
(\mathbf{0}-4)\end{array}$ & $\begin{array}{c}\text { I3- without government } \\
\text { registration } \\
(\mathbf{0}-4)\end{array}$ \\
\hline Male 15+ & 2.6098 & 2.6001 \\
\hline Female15+ & 2.2693 & 2.2300 \\
\hline Test significance & 0.000 & 0.000 \\
\hline Male/female relative gap & 1.15 & 1.17 \\
\hline Total 15+ & 2.42 & 2.39 \\
\hline Male 15-29 & 2.6039 & 2.5922 \\
\hline Female 15-29 & 2.2606 & 2.2153 \\
\hline Test significance & 0.000 & 0.000 \\
\hline Male/female relative gap & 1.15 & 1.17 \\
\hline Total 15-29 & 2.41 & 2.38 \\
\hline
\end{tabular}

Source: Author's calculations from the Egypt Labor Market Panel Survey 2006.

Figure (4): Gender gap in $\mathrm{I}_{3}$-Considering using new job search methods
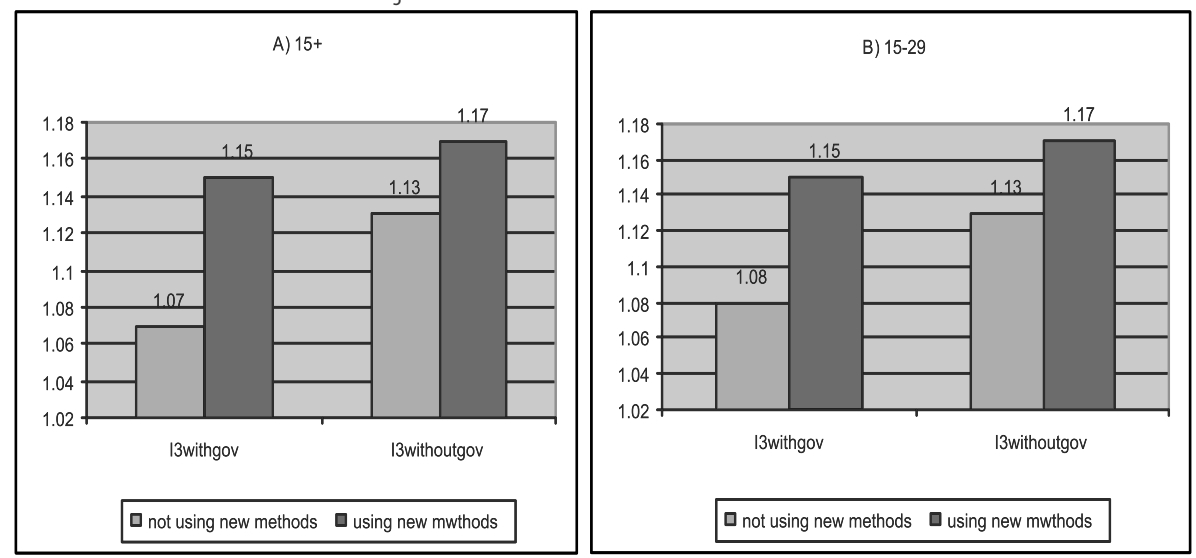

Source: Author's calculations from the Egypt Labor Market Panel Survey 2006.

\subsubsection{Job Search Efficiency Index 2 (JSE2) (1998-2006)}

Table (2I) illustrates job search efficiency Index2 (JSE2) for unemployed job searchers; all the unemployed and the unemployed youth, male and female. JSE2 is a composite index that measures the efficiency of job search behavior considering using new methods as complementary to traditional ones ${ }^{6}$.

6 Refer to equation (8). 
Table (21): Job Search Efficiency Index2 (JSE2)-2006

\begin{tabular}{|l|c|c|}
\hline & $\begin{array}{c}\text { JSE2-with government } \\
\text { registration }\end{array}$ & $\begin{array}{c}\text { JSE2-without government } \\
\text { registration }\end{array}$ \\
\hline Male 15+ & 0.4432 & 0.4355 \\
\hline Female15+ & 0.3579 & 0.3423 \\
\hline Test significance & 0.000 & 0.000 \\
\hline Male/female relative gap & 1.24 & 1.27 \\
\hline Total 15+ & 0.39 & 0.38 \\
\hline Male 15-29 & 0.4473 & 0.4388 \\
\hline Female 15-29 & 0.3522 & 0.3365 \\
\hline Test significance & 0.000 & 0.000 \\
\hline Male/female relative gap & 1.27 & 1.30 \\
\hline Total 15-29 & 0.39 & 0.38 \\
\hline
\end{tabular}

Source: Author's calculations from the Egypt Labor Market Panel Survey 2006.

Comparing JSEI and JSE2 reveals that JSEr is higher than JSE2 for all the unemployed and unemployed youth job searchers and for both genders. We reach this result whether registering in government employment offices is included or excluded from job search methods. Thus, considering using new job search methods leads to lower job efficiency index in the Egyptian labor market, simply because using these new search methods are very limited in spite of the fact that using them result in many benefits for both job searchers and employers.

The gender gap in JSE2 is wider than the gender gap in JSEI, as the gender gap in using new job search methods is wider than the gender gap in using traditional methods.

According to both JSEI and JSE2, the least active unemployed job searchers in the Egyptian labor market are unemployed young women job searchers.

\section{Determinants of Women's Job Search Behavior in Egypt}

As previously mentioned, relatively few empirical studies attempt to analyze main determinants of job search behavior. Few studies were conducted to analyze these determinants in developing countries, none in Egypt. The main determinants of job search behavior may be classified in three main groups; personal characteristics, household, and labor market conditions: 


\subsection{Personal Characteristics}

Personal characteristics that determine job search behavior include age, education, unemployment duration, and previous work experience.

\subsubsection{Age}

Table (22) illustrates differences in female unemployed job searchers' job search behavior measures by age.

Table (22): Age and Women's Job Search Behavior

\begin{tabular}{|l|c|c|c|c|c|c|c|}
\hline & $\mathrm{I}_{1}$ & $\mathrm{I}_{2}$ & $\mathrm{I}_{3}$ & JSE1 & JSE2 & Formal & Informal \\
\hline $12-14$ & 0.00 & 0.00 & 0.00 & 0.00 & 0.00 & 0.00 & 0.00 \\
\hline $15-19$ & 0.69 & 1.82 & 1.03 & 0.33 & 0.24 & 0.56 & 0.46 \\
\hline $20-29$ & 0.85 & 2.96 & 1.35 & 0.46 & 0.37 & 0.81 & 0.54 \\
\hline $30-39$ & 0.88 & 3.24 & 1.39 & 0.48 & 0.40 & 0.86 & 0.53 \\
\hline $40-49$ & 0.76 & 2.69 & 0.95 & 0.35 & 0.33 & 0.56 & 0.39 \\
\hline $50-59$ & 0.00 & 0.00 & 0.00 & 0.00 & 0.00 & 0.00 & 0.00 \\
\hline Significance & 0.000 & 0.000 & 0.000 & 0.000 & 0.000 & 0.000 & 0.000 \\
\hline
\end{tabular}

Source: Author's calculations from the Egypt Labor Market Panel Survey 2006.

Figure (5): Age and Women's Job Search Behavior

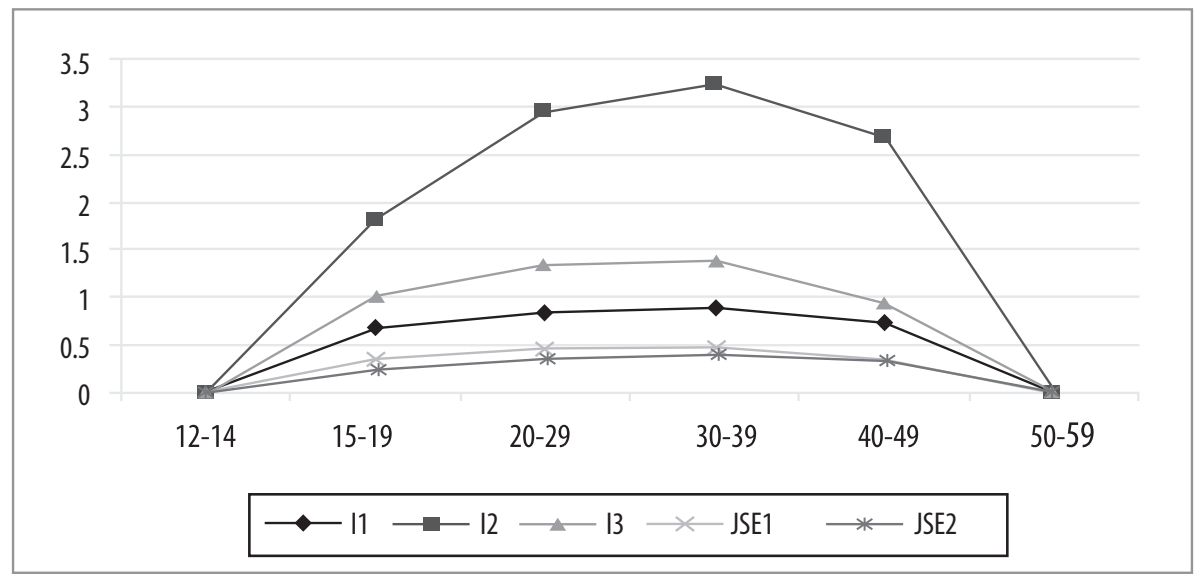

Source: Author's calculations from the Egypt Labor Market Panel Survey 2006.

There is an inverse- $U$ shaped relation between age and women's job search behavior (Figure 5). Up till age forty, old aged female unemployed job searchers are more active than younger ones. After that, females become less active as they get older. Unemployed females (50+) are not active in job search. 


\subsubsection{Education}

Table (23) illustrates differences in female unemployed job searchers' job search behavior measures by educational level.

Table (23): Educational Level and Women's Job Search Behavior

\begin{tabular}{|l|c|c|c|c|c|c|c|}
\hline & $\mathrm{I}_{1}$ & $\mathrm{I}_{2}$ & $\mathrm{I}_{3}$ & JSE1 & JSE2 & Formal & Informal \\
\hline $\begin{array}{l}\text { No school } \\
\text { certificate }\end{array}$ & 0.34 & 0.60 & 0.50 & 0.15 & 0.09 & 0.26 & 0.24 \\
\hline Basic education & 0.61 & 1.52 & 1.01 & 0.32 & 0.26 & 0.41 & 0.61 \\
\hline $\begin{array}{l}\text { Secondary } \\
\text { education }\end{array}$ & 0.85 & 2.77 & 1.33 & 0.45 & 0.34 & 0.80 & 0.53 \\
\hline $\begin{array}{l}\text { Post secondary } \\
\text { education and } \\
\text { above }\end{array}$ & 0.84 & 3.13 & 1.32 & 0.46 & 0.40 & 0.80 & 0.52 \\
\hline Significance & 0.000 & 0.000 & 0.000 & 0.000 & 0.000 & 0.000 & 0.000 \\
\hline
\end{tabular}

Source: Author's calculations from the Egypt Labor Market Panel Survey 2006.

The higher educated females are more active job searchers than the lower educated females. All job search measures are higher, the higher the educational level is. On one hand, the higher educated have a higher incentive to search for work; the higher educated females have better opportunities in the labor market, thus the job search is expected to pay them off more than for the lower educated. The expected returns of higher educated females are higher, it is estimated that earnings of females $\left(\mathrm{I}^{+}\right)$ with post secondary education and above are 3.5, 28.2, 68.4 times higher than earnings of females with secondary education, basic education, and no school certificate respectively?. On the other hand, higher educated females are more able to conduct a job search using different methods.

Concerning job search methods, the higher educated use both formal and informal methods more intensively than the lower educated. However, the relative gap is wider in the case of formal job search methods. The better educated are better informed about formal job search methods such as registering in a private employment office, entering government job lottery competitions, and are also better qualified to use them.

\subsubsection{Unemployment Duration}

Table (24) illustrates differences in female unemployed job searchers' job search behavior measures by unemployment duration.

7 Author's calculations from the Egypt Labor Market Panel Survey 2006. 
Table (24): Unemployment Duration and Women's Job Search Behavior

\begin{tabular}{|c|c|c|c|c|c|c|c|}
\hline & $\mathrm{I}_{1}$ & $\mathrm{I}_{2}$ & $\mathrm{I}_{3}$ & JSE1 & JSE2 & Formal & Informal \\
\hline 1 & 0.68 & 1.90 & 1.04 & 0.34 & 0.27 & 0.55 & 0.49 \\
\hline 2 & 0.70 & 2.55 & 1.18 & 0.40 & 0.32 & 0.72 & 0.47 \\
\hline 3 & 0.85 & 3 & 1.37 & 0.47 & 0.37 & 0.83 & 0.54 \\
\hline 4 & 0.95 & 3.22 & 1.49 & 0.51 & 0.42 & 0.93 & 0.56 \\
\hline 5 & 0.89 & 3.42 & 1.42 & 0.50 & 0.41 & 0.84 & 0.57 \\
\hline Significance & 0.000 & 0.000 & 0.000 & 0.000 & 0.000 & 0.000 & 0.000 \\
\hline
\end{tabular}

Source: Author's calculations from the Egypt Labor Market Panel Survey 2006.

Longer unemployment duration puts more pressure on the unemployed to search for work (Table 24). According to the unemployment duration (measured in months), the unemployed were classified in five quintiles. The unemployed in the first quintile have been unemployed for ten months or less, while those in the fifth quintile have been unemployed for more than 96 months ( 8 years). The higher the unemployment duration is, the higher the job search measures are.

\subsubsection{Previous Work Experience}

Table (25) reports differences in female unemployed job searchers' job search behavior measures by main characteristics of previous work experience; including, the existence of previous employment experience, length of work experience and type of previous work; formal or informal.

Table (25): Previous work experience and women's job search behavior

\begin{tabular}{|c|c|c|c|c|c|c|c|}
\hline & $\mathrm{I}_{1}$ & $\mathrm{I}_{2}$ & $\mathrm{I}_{3}$ & JSE1 & JSE2 & Formal & Informal \\
\hline \multicolumn{8}{|c|}{1 . Working before } \\
\hline Did not work before & 0.8357 & 2.8 & 1.30 & 0.442 & 0.354 & 0.79 & 0.51 \\
\hline Significance & 0.000 & 0.000 & 0.000 & 0.000 & 0.000 & 0.000 & 0.000 \\
\hline \multicolumn{8}{|c|}{ 2. Length of work experience } \\
\hline 1 & 0.871 & 3.3 & 1.53 & 0.52 & 0.43 & 0.83 & 0.70 \\
\hline 2 & 0.753 & 2.9 & 1.26 & 0.44 & 0.35 & 0.69 & 0.58 \\
\hline 3 & 0.735 & 2.9 & 1.22 & 0.43 & 0.35 & 0.62 & 0.60 \\
\hline 4 & 0.445 & 0.445 & 0.445 & 0.13 & 0.13 & 0.000 & 0.44 \\
\hline 5 & 0.000 & 0.000 & 0.000 & 0.000 & 0.000 & 0.000 & 0.000 \\
\hline Significance & 0.000 & 0.000 & 0.000 & 0.000 & 0.000 & 0.000 & 0.000 \\
\hline
\end{tabular}




\begin{tabular}{|c|c|c|c|c|c|c|c|}
\hline \multicolumn{8}{|c|}{ 3. Formal/informal work } \\
\hline With contract & 0.75 & 2.6 & 1.3 & 0.44 & 0.39 & 0.75 & 0.54 \\
\hline Without contract & 0.85 & 2.4 & 1.45 & 0.50 & 0.42 & 0.77 & 0.68 \\
\hline Significance & 0.000 & 0.000 & 0.000 & 0.000 & 0.000 & 0.000 & 0.000 \\
\hline
\end{tabular}

Source: Author's calculations from the Egypt Labor Market Panel Survey 2006.

Females with previous working experience are significantly more active in the job search than female new entrants.

Unemployed females with previous experience are more likely than new entrants to use informal search methods, as opposed to using formal search methods. The first group managed to build social networks during working that may help them in finding a job, while the second group lacks access to such networks.

Concerning the length of work experience, an index has been developed to measure length of work experience $=2006$-year of entering the labor market. Depending on this measure, females were grouped in 5 quintiles. The length of experience is less than 7 years for first quintile; it ranges from $8^{-} \mathrm{I} 3$ years for second quintile; $\mathrm{I}^{-22}$ years for third quintile; $23^{-36}$ years for fourth quintile and $37^{+}$years for fifth quintile. Comparing job search measures across these five quintiles, it is found that the higher the length of work experience, the less active the job search behavior and the more likely they are to use informal rather than formal search methods. This is obvious in the fourth and fifth quintiles ( $23+$ years) compared to the first three quintiles.

Those who previously were working informally (without a contract) are more active in job search than those who previously were working formally. The first group is also more likely to use an informal job search method than those who previously were working formally.

\subsection{Household Characteristics}

Household characteristics that determine job search behavior include household economic conditions, dependency ratio, marital status, presence of children, social background, and residence.

\subsubsection{Economic Conditions}

Table (26) reports differences in female unemployed job search behavior measures by household economic conditions. 
Table (26): Wealth and Women's Job Search Behavior

\begin{tabular}{|c|c|c|c|c|c|c|c|}
\hline Wealth Quintiles & $\mathrm{I}_{1}$ & $\mathrm{I}_{2}$ & $\mathrm{I}_{3}$ & JSE1 & JSE2 & Formal & Informal \\
\hline \multicolumn{8}{|c|}{ Females } \\
\hline 1 & 0.72 & 2.2 & 1.06 & 0.36 & 0.27 & 0.64 & 0.42 \\
\hline 2 & 0.77 & 2.5 & 1.16 & 0.39 & 0.30 & 0.71 & 0.45 \\
\hline 3 & 0.85 & 2.9 & 1.35 & 0.46 & 0.34 & 0.77 & 0.58 \\
\hline 4 & 0.88 & 3 & 1.36 & 0.47 & 0.38 & 0.85 & 0.50 \\
\hline 5 & 0.86 & 3.2 & 1.42 & 0.49 & 0.43 & 0.81 & 0.61 \\
\hline Significance & 0.000 & 0.000 & 0.000 & 0.000 & 0.000 & 0.000 & 0.000 \\
\hline $\begin{array}{l}\text { Relative gap (fifth/ } \\
\text { first quintile) }\end{array}$ & 1.2 & 1.5 & 1.34 & 1.36 & 1.59 & 1.27 & 1.45 \\
\hline \multicolumn{8}{|c|}{ Males } \\
\hline 1 & 0.81 & 3.1 & 1.3 & 0.45 & 0.34 & 0.77 & 0.51 \\
\hline 2 & 0.89 & 3.4 & 1.5 & 0.51 & 0.40 & 0.83 & 0.65 \\
\hline 3 & 0.91 & 3.7 & 1.6 & 0.55 & 0.43 & 0.87 & 0.69 \\
\hline 4 & 0.88 & 3.5 & 1.5 & 0.51 & 0.44 & 0.85 & 0.61 \\
\hline 5 & 0.90 & 4.1 & 1.6 & 0.56 & 0.53 & 0.88 & 0.68 \\
\hline Significance & 0.000 & 0.000 & 0.000 & 0.000 & 0.000 & 0.000 & 0.000 \\
\hline $\begin{array}{l}\text { Relative gap (fifth/ } \\
\text { first quintile) }\end{array}$ & 1.11 & 1.32 & 1.23 & 1.24 & 1.56 & 1.14 & 1.33 \\
\hline
\end{tabular}

Source: Author's calculations from the Egypt Labor Market Panel Survey 2006.

The wealth index is a composite index constructed using the ELMPS o6 data. It is constructed from several indicators measuring the economic level of the household. Those surveyed were grouped into five quintiles according to the wealth index.

Comparing unemployed female job search measures across the five quintiles, it is found that contrary to expectations, the higher the household economic level is, the more active females are in the job search.

However, comparing reasons for not being active among unemployed females in the lowest two quintiles to reasons for not being active among the highest three quintiles may explain part of this difference.

Expecting that there are no jobs is the main reason. However, it is more important among the lowest two quintiles $(58 \%$ and $42 \%)$. This is simply because they are less educated; they do not expect to find a job easily. Low level of education is the reason for $2.7 \%$ of the lowest two quintiles comparing with $\mathrm{I} .5 \%$ among the highest three quintiles. Besides, due to their low level of education, they expect to work in jobs where males are most likely to be preferred (5.49\% compared with $\mathrm{I.9} \%)$. In addition, they 
are more likely to work inside the household and not to be allowed to work (8.8\% compared with $7.1 \%)$.

Compared with males, the gap among females of different wealth quintiles is wider. Males have to search for work to support their families according to traditional norms; they do not have the option to stay at home contrary to females.

It is worth mentioning that concerning job search methods:

a) The gap in using informal methods is wider. This reflects differences in the quality of social networks between different wealth quintiles. Job searchers in the highest wealth quintile are more likely to have relatives and friends who are more able to help them have a job of a good quality.

b) The gap between job searchers from different wealth quintiles in JSE2 "considering using new search methods" is wider than gap in JSEr. This is expected, considering differences in the level of education and in the ability to get access to a personal computer at home (Table 27).

Table (27): Wealth, females' education and having a computer in the HH \%

\begin{tabular}{|l|c|c|c|c|c|c|}
\hline \multirow{2}{*}{ Education } & \multicolumn{7}{|c|}{ Wealth Quintiles } \\
\cline { 2 - 8 } & $\mathbf{1}$ & $\mathbf{2}$ & $\mathbf{3}$ & $\mathbf{4}$ & $\mathbf{5}$ & All \\
\hline No school certificate & 76.3 & 60.3 & 48.3 & 33.9 & 23.7 & 48.5 \\
\hline Basic education & 14.1 & 17.1 & 19.3 & 19.5 & 18.3 & 17.7 \\
\hline Secondary education & 9.1 & 19.6 & 25.2 & 31.9 & 29.5 & 23.1 \\
\hline Post secondary education & 0.5 & 3 & 7.2 & 14.6 & 28.5 & 10.8 \\
\hline HH owing a computer & 0 & 0.4 & 1.6 & 7.4 & 35.5 & 8.8 \\
\hline
\end{tabular}

Chi-square sig. at 0.01 level.

Source: Author's calculations from the Egypt Labor Market Panel Survey 2006.

\subsubsection{HH size and presence of children}

Table (28) illustrates differences in female unemployed job search behavior measures by dependency ratio, marital status and presence of children.

Table (28): Household Size, Presence of Children and Women's Job Search Behavior

\begin{tabular}{|c|c|c|c|c|c|c|c|}
\hline & $\mathrm{I}_{1}$ & $\mathrm{I}_{2}$ & $\mathrm{I}_{3}$ & JSE1 & JSE2 & Formal & Informal \\
\hline \multicolumn{8}{|c|}{ 1. Dependency Ratio } \\
\hline High dependency ratio & 0.86 & 3 & 1.3 & 0.46 & 0.38 & 0.81 & 0.54 \\
\hline Low dependency ratio & 0.79 & 2.6 & 1.2 & 0.42 & 0.32 & 0.73 & 0.50 \\
\hline Significance & 0.000 & 0.000 & 0.000 & 0.000 & 0.000 & 0.000 & 0.000 \\
\hline
\end{tabular}




\begin{tabular}{|c|c|c|c|c|c|c|c|}
\hline \multicolumn{8}{|c|}{ 2. Presence of Children } \\
\hline $\begin{array}{c}\text { Do not have children } \\
\text { (in HH) }\end{array}$ & 0.88 & 2.8 & 1.4 & 0.46 & 0.346 & 0.80 & 0.57 \\
\hline $\begin{array}{c}\text { Having Children } \\
\text { (in HH) }\end{array}$ & 0.85 & 2.9 & 1.3 & 0.44 & 0.349 & 0.81 & 0.46 \\
\hline Significance & 0.000 & 0.000 & 0.000 & 0.000 & 0.000 & 0.000 & 0.04 \\
\hline \multicolumn{7}{|c|}{3. Marital Status and Presence of Children } \\
\hline $\begin{array}{c}\text { Not married, no } \\
\text { children }\end{array}$ & 0.82 & 2.8 & 1.3 & 0.45 & 0.36 & 0.75 & 0.57 \\
\hline Married, no children & 0.89 & 2.9 & 1.4 & 0.47 & 0.35 & 0.83 & 0.56 \\
\hline $\begin{array}{c}\text { Not married, with } \\
\text { children }\end{array}$ & 0.95 & 3.3 & 1.5 & 0.52 & 0.44 & 0.95 & 0.60 \\
\hline Married with children & 0.84 & 2.8 & 1.3 & 0.44 & 0.35 & 0.80 & 0.45 \\
\hline Significance & 0.000 & 0.000 & 0.000 & 0.000 & 0.000 & 0.000 & 0.000 \\
\hline
\end{tabular}

Source: Author's calculations from the Egypt Labor Market Panel Survey 2006.

Households surveyed were divided into two main groups according to dependency ratio. The first group has a dependency ratio greater than the average dependency ratio of all households surveyed; the second has a dependency ratio lower than the average dependency ratio of all households surveyed. Comparing women's job search behavior between the two groups shows that job search behavior varies significantly between the two groups. Those females living in households where the dependency ratio is higher are more active in job search as high dependency ratio puts more pressure on them to search for work.

Women with children are generally less active in the job search. However, while women who have children in the household are less likely than women with no children in the household to search for a job, when they search for a job, they search more intensively. When they search for a job, they need to work more than those with no children, thus they search more intensively. This would be obvious comparing job search behavior among women with different marital status, with and without children.

The study classified women in four groups according to both marital status and the presence of children in the household. These four groups are:

(I) Not married with no children

(2) Married with no children

(3) Not married with children

(4) Married with children 
Evaluating differences in job search behavior among these four groups, we may conclude that women who are not married and have children in the household are the most active in job search, followed by married women with no children. The first group needs to work to support their children while the second has no children to take care for and have enough time to search for work. The other two groups are less active in the job search. Married women with children have other responsibilities which are time consuming and they expect their husbands to work to support their households; the other group is those unmarried with no children.

\subsubsection{Social Background}

One of the main social background characteristics that affect females' education and their labor market activity is their mother's educational level and employment status.

Table (29): Social Background and Women's Job Search Behavior

\begin{tabular}{|c|c|c|c|c|c|c|c|}
\hline & $\mathrm{I}_{1}$ & $\mathrm{I}_{2}$ & $\mathrm{I}_{3}$ & JSE1 & JSE2 & Formal & Informal \\
\hline \multicolumn{8}{|c|}{ 1.Mother's Education } \\
\hline Below secondary & 0.85 & 2.8 & 1.3 & 0.44 & 0.34 & 0.81 & 0.47 \\
\hline $\begin{array}{c}\text { Secondary and } \\
\text { above }\end{array}$ & 0.87 & 3.3 & 1.4 & 0.48 & 0.42 & 0.79 & 0.58 \\
\hline Significance & 0.000 & 0.000 & 0.000 & 0.000 & 0.000 & 0.000 & 0.000 \\
\hline \multicolumn{8}{|c|}{2. Mother's Employment Status } \\
\hline Not a wage worker & 0.85 & 2.8 & 1.29 & 0.44 & 0.34 & 0.81 & 0.48 \\
\hline A wage worker & 0.87 & 3.1 & 1.31 & 0.46 & 0.41 & 0.77 & 0.53 \\
\hline Significance & 0.000 & 0.000 & 0.000 & 0.000 & 0.000 & 0.000 & 0.000 \\
\hline
\end{tabular}

Source: Author's calculations from the Egypt Labor Market Panel Survey 2006.

Females whose mothers completed secondary education and above are more active in the job search than females whose mothers are less educated. In addition, the first group is more likely to use informal search methods than the first group. They usually come from households enjoying better economic conditions and have better social networks.

If the mother has been a wage worker, females are more likely to search for work intensively and also to use informal search methods. Working mothers are more likely to have stronger social networks that may help in finding work. 


\subsubsection{Residence}

Table (30): Residence and Women's Job Search Behavior

\begin{tabular}{|c|c|c|c|c|c|c|c|}
\hline & $\mathrm{I}_{1}$ & $\mathrm{I}_{2}$ & $\mathrm{I}_{3}$ & JSE1 & JSE2 & Formal & Informal \\
\hline Urban & 0.832 & 3.05 & 1.4 & 0.47 & 0.40 & 0.78 & 0.59 \\
\hline Rural & 0.834 & 2.65 & 1.2 & 0.42 & 0.32 & 0.79 & 0.45 \\
\hline Significance & 0.002 & 0.000 & 0.000 & 0.000 & 0.000 & 0.000 & 0.000 \\
\hline
\end{tabular}

Source: Author's calculations from the Egypt Labor Market Panel Survey 2006.

Unemployed females in urban areas are more active in the job search than those in rural areas. This is consistent with both search theory and empirical literature. In urban areas, there are more job opportunities for females, thus their job search is more likely to pay off. Average earnings of females $\left(\mathrm{I}^{+}\right)$in urban areas are 2.7 times higher than average earnings in rural areas. ${ }^{8}$

In addition, unemployed females in urban areas are more likely to use informal search methods while those in rural areas are more likely to use formal search methods. Those in urban areas have social networks that may be more helpful in the labor market.

\subsection{Labor Market Conditions}

Table (31): Labor Market Conditions and Women's Job Search Behavior

\begin{tabular}{|c|c|c|c|c|c|c|c|}
\hline & $\mathrm{I}_{1}$ & $\mathrm{I}_{2}$ & $\mathrm{I}_{3}$ & JSE1 & JSE2 & Formal & Informal \\
\hline \multicolumn{8}{|c|}{ 1.Unemployment Rate } \\
\hline $\begin{array}{l}\text { Unemployment rate } \\
\text { lower than average }\end{array}$ & 0.84 & 2.76 & 1.28 & 0.44 & 0.33 & 0.76 & 0.521 \\
\hline $\begin{array}{l}\text { Unemployment rate } \\
\text { higher than average }\end{array}$ & 0.83 & 2.9 & 1.31 & 0.45 & 0.37 & 0.79 & 0.524 \\
\hline Significance & 0.000 & 0.000 & 0.000 & 0.000 & 0.000 & 0.000 & 0.000 \\
\hline \multicolumn{8}{|c|}{ 2. Region } \\
\hline Greater Cairo & 0.75 & 2.4 & 1.21 & 0.40 & 0.37 & 0.65 & 0.56 \\
\hline Alex and Suez Canal & 0.99 & 4.6 & 1.76 & 0.63 & 0.57 & 0.92 & 0.84 \\
\hline Urban Lower Egypt & 0.88 & 3.3 & 1.50 & 0.51 & 0.40 & 0.84 & 0.65 \\
\hline Urban Upper Egypt & 0.75 & 2.5 & 1.06 & 0.37 & 0.29 & 0.75 & 0.31 \\
\hline Rural Lower Egypt & 0.88 & 2.8 & 1.34 & 0.45 & 0.35 & 0.85 & 0.49 \\
\hline Rural Upper Egypt & 0.73 & 2.2 & 0.99 & 0.34 & 0.25 & 0.63 & 0.36 \\
\hline Significance & 0.000 & 0.000 & 0.000 & 0.000 & 0.000 & 0.000 & 0.000 \\
\hline
\end{tabular}

Source: Author's calculations from the Egypt Labor Market Panel Survey 2006.

8 Author's calculations from the Egypt Labor Market Panel Survey 2006. 
Depending on the unemployment rate in Egypt and in different governorates, the surveyed unemployed are divided in two groups according to labor market conditions. The first group lives in areas where the unemployment rate is lower than the average unemployment rate in Egypt, and the other group lives in areas where the unemployment rate is higher than average. Females living in areas where the unemployment rate is higher than the national average are more active in the job search than those living in areas, where the unemployment rate is lower than the national average.

Comparing female job search behavior by region, we may reach the same conclusion that the higher the unemployment rate is; the more active their job search is. Regions with the highest unemployment rate and female unemployment rate; Alex and Suez Canal, Urban Lower Egypt in urban areas, Rural Lower Egypt in rural areas ${ }^{9}$, have the highest job search measures; higher than the national average. Job searchers in these areas are also more likely to use informal job search methods.

\subsection{Economic Model to Estimate Determinants of Women's Job Search Behavior}

\subsubsection{Economic Model}

The model used here to estimate determinants of women's job search behavior in Egypt follows the methodology of Eriksson, Lilja and Torp (2002), Boheim and Taylor (2002), and Sminrova (2003).

The job search activity is decomposed into three main decisions as follows:

First, deciding whether to search or not.

Second, deciding how intensively to search.

Third, deciding the job search methods used.

These three decisions may be described with a three equation structural model as follows:

$\mathrm{I}_{\mathrm{rit}}=\mathrm{I}_{\mathrm{I}}\left(\mathrm{P}_{\mathrm{it}}, \mathrm{H}_{\mathrm{it}}, \mathrm{L}_{\mathrm{it}}\right)$, (job search propensity equation) (9)

$\mathrm{I}_{2 \mathrm{ti}}=\mathrm{I}_{2}\left(\mathrm{P}_{\mathrm{it}}, \mathrm{H}_{\mathrm{it}}, \mathrm{L}_{\mathrm{it}}\right)$ (job search intensity equation) (IO)

$\mathrm{SM}_{\mathrm{ijt}}=\mathrm{SM}\left(\mathrm{P}_{\mathrm{it}}, \mathrm{H}_{\mathrm{it}}, \mathrm{L}_{\mathrm{it}}\right)$, (job search method choice equation) (II)

Where $\mathrm{I}_{\text {rit }}$ is the job search propensity of the $\mathrm{i}^{\text {th }}$ individual, $\mathrm{I}_{2}$ it is the job search intensity of the $i^{\text {th }}$ individual measured by the number of methods used; $\mathrm{SM}_{\mathrm{ijt}}$ measures the propensity to use the search method $\mathrm{j}$ by the $\mathrm{i}^{\text {th }}$ individual.

9 Unemployment rates are: $10.2 \%, 13.1 \%$ and $9.3 \%$, female unemployment rates are: $19.1 \%, 31.1 \%$, and $25.6 \%$ respectively (Assaad, 2009). 
$\mathrm{P}_{\text {it }}$ is a set of personal characteristics, $\mathrm{H}_{\text {it }}$ is a set of characteristics of individual's household, and Lit is specific labor market characteristics.

In this study, two more equations are added; using the two composite indices developed here to measure job search efficiency:

$\mathrm{JSEI}_{\mathrm{it}}=\mathrm{J}_{\text {rit }}\left(\mathrm{P}_{\mathrm{it}}, \mathrm{H}_{\mathrm{it}}\right)$, (job search efficiency Indexi equation) (I2)

$\mathrm{JSE}_{2}{ }_{\mathrm{it}}=\mathrm{J}_{2 \mathrm{it}}\left(\mathrm{P}_{\mathrm{it}}, \mathrm{H}_{\mathrm{it}}\right)$, (job search efficiency Index2 equation) (I3)

Where JSEI ${ }_{\text {it }}$ ranges from o to I, where o refers to less active job search, I refers to highly active job search, where the cut point is the average JSEI for unemployed females. JSE ${ }_{i t}$ ranges from o to $\mathrm{I}$, where $\mathrm{O}$ refers to a less active job search considering using new search methods as supplementary to traditional ones, I refers to a highly active job search considering using new search methods as supplementary to traditional ones, where the cut point is the average JSE2 for unemployed females.

Equations (9), (IO), (II), (I2) and (I3) constitute the model of individual i's job search behavior.

These equations include personal, household, and employment characteristics as linear independent variables.

$P_{i t}$ is a vector of personal characteristics that includes age, education, unemployment duration, and previous work experience; $\mathrm{H}_{\mathrm{it}}$ is a vector of an individual's household characteristics that includes economic conditions, household size, dependency ratio, and marital status. Lit is a vector of labor market characteristics that includes unemployment rate.

However, in the ELMPSo6, the questions related to job search behavior are asked only to unemployed individuals. Thus, there is a sample selection problem. Since the estimations based only on unemployment criterion, i.e. ignoring the selection bias, may lead to biased and inconsistent results, there is a need to tackle this problem. The most common approach used in the literature to solve this issue is Heckman's (1979) two-step procedure, in which, we jointly model selection into the sample, i.e. unemployment, and the final outcome, i.e. job-search propensity, intensity, methods used, JSEI and JE2. Hence, the effects of individual and labor market properties on the job search behavior measures are estimated by employing "selectivity corrected" logistic models. There are two stages in this approach. In the first stage of the model we estimate the unemployment choice of the survey respondents, where the independent variable is "unemployed;" it is a dummy variable taking the value of $\mathrm{I}$ if the respondent is unemployed, and zero otherwise. In the second stage, the determinants of job search propensity, intensity, method choice, etc. is estimated. This approach follows the methodology of other job search literature (Eriksson, Lilja and Torp, 2002; Tasci, 2008). 
The list of variables used in the first stage of the model "unemployment choice" includes: age, education, previous working experience, wealth, household size, I/dependency ratio, etc.

The Heckman model requires that the selection equation; unemployment choice equation here, contains at least one variable that is not related to the dependent variable in the substantial equation (Smits, 2003); the job search measure equation here. This variable affects unemployment but does not directly affect the outcome studied; which is job search behavior measures, except through its effect on unemployment.

Macroeconomic conditions as shown in different literature significantly affect unemployment (Tasci, 2008; Tansel, 2002; Baker et al., 2004; and Berument, Dogan and Tansel, 2006). Economic development measured by GDP per capita in the province/state level have been used as a determinant of the probability of being unemployed as shown in different economic literature (Tasci, 2008; Tansel, 2002; Berument, Dogan and Tansel, 2006). Focusing on women, a higher per capita GDP is generally accompanied by a higher female participation and employment rates (Perugini and Signorelli, 2007).

\subsubsection{Determinants of Women's Job search Propensity $\left(I_{1}\right)$}

$\mathrm{I}_{\mathrm{I}}$ is job search propensity, where:

$$
\begin{aligned}
& \mathrm{I}_{\text {rait }}=\alpha_{0}+\alpha_{\mathrm{I}} \mathrm{P}_{\text {it }}+\alpha_{2} \mathrm{H}_{\text {it }}+\alpha_{3} \mathrm{~L}_{\text {it }}+\varepsilon_{\text {it }}(\mathrm{I} 4) \\
& \mathrm{I}_{\mathrm{rbit}}=\alpha_{\mathrm{o}}+\alpha_{\mathrm{I}} \mathrm{P}_{\mathrm{it}}+\alpha_{2} \mathrm{H}_{\mathrm{it}}+\alpha_{3} \mathrm{~L}_{\mathrm{it}}+\varepsilon_{\mathrm{it}}(\mathrm{I} 5)
\end{aligned}
$$

Where: $I_{\text {rit }}=\mathrm{I}$ if individual $\mathrm{i}$ is searching for a job and $\mathrm{I}_{\mathrm{rit}}=\mathrm{O}$ if she is not searching (did not use any search method to find a job). $\mathrm{I}_{\text {rbit }}$ indicates job search propensity excluding registering in a government employment office. $\mathrm{P}_{\mathrm{it}}, \mathrm{Hit}_{\mathrm{it}}$ and $\mathrm{L}_{\mathrm{it}}$ are personal, household characteristics, and labor market conditions respectively.

The dependent variable $\left(\mathrm{I}_{\mathrm{rit}}\right)$ is a dichotomous indicator. Thus, the binary logistic model is used for estimation.

Table ( $\mathrm{IA}$ and $\mathrm{IB}$ ) of the appendix shows the results of binary logistic regression of the job search propensity two equations. The likelihood ratio chi-square shows that the overall model fit is good, a p-value of o.ooor. All coefficient estimates are significant at the i\% level.

Concerning personal characteristics: First, age: the results show that parameter estimates for females younger than 40 is positive, except for those younger than 15 , suggesting that job search propensity increases for females ( $\left.15^{-39}\right)$. The relationship between age and job search propensity is inverse $\mathrm{U}$ shaped. Unemployed people, in their prime work age, male or female, are expected to be the most active in their job search (Smirnova, 2003). However, it is worth mentioning that the odds of doing a job search 
for females (30-39) are ceteris paribus 3.6 times as likely as for females (4O+), while the odds of doing a job search for female unemployed youth (15-29) are ceteris paribus 2.I times as likely as for females (40+). Young females are less active than females aged $30^{-}$-39. Second, educational level: consistent with both literature and empirical evidence, women's education positively affects their job search activity. The odds of doing a job search for women below secondary education are ceteris paribus 0.76 times as likely as for women with secondary education and above. Unemployed women who have completed secondary education tend to search for work more actively than those unemployed women without such education. Third, previous work experience significantly affects the job search, the odds that a woman with a previous work experience is ceterisparibus 0.988 times as likely as for one with no previous work experience to search for a job. The difference seems relatively small, indicating higher job search propensity for new entrants. However, excluding registering in a government employment office, it is found that those females with previous work experience have a higher job search propensity than new entrants; the odds that a woman with previous work experience is ceteris paribus $\mathrm{I} .43$ times as likely as for one with no previous work experience to search for a job.

Concerning household characteristics: First, wealth: unemployed women from wealthier households are more active in doing a job search; for every one unit increase in the wealth index, the odds of doing a job search (versus not searching) increases by a factor of I.34. Those women usually have higher aspirations. Second: household size negatively affects women's job search propensity. Those living in larger households tend to have more domestic responsibilities than those living in smaller households. These domestic responsibilities usually are time consuming. Third, higher independency ratio results in more pressure on females to conduct a job search. Fourth, marital status, married females are more active in the job search than unmarried females. This is mainly due to the economic circumstances in Egypt; high inflation rates and high poverty rates that make it necessary for married women to help their husbands to support their families. Being the head of the household raises the need to look for additional income, this in turn results in a higher job search propensity for women who are the head of their households. The odds of doing a job search for a female who is not the head of the household is ceteris paribus 0.002 times as likely as for a female who is a head of the household. However, excluding registering in a government employment office, women who are not head of their families have higher job search propensity.

Concerning labor market characteristics; where the unemployment rate is higher women are more likely to do a job search. The odds ratio 
is highest for Alexandria and the Suez Canal where; the odds of doing a job search for unemployed females in this region are 23.3 times as likely as for females in rural Upper Egypt. In Upper Egypt, less job opportunities are available for women, in addition considering payment levels and job quality; these limited job opportunities do not provide incentives for doing a job search considering the search benefits and costs contrary to Alexandria and Suez Canal governorates where women's job search is more likely to pay off.

\subsubsection{Determinants of Women's Job search Intensity $\left(\mathrm{I}_{2}\right)$}

$\mathrm{I}_{2}$ measures job search intensity using the total number of job search methods used. Following the methodology adopted in job search literature (Eriksson, Lilja and Torp, 2002; Tasci, 2008; and Smirova, 2003), job search intensity is measured by the number of job search methods used; it is an ordinal qualitative variable.

$$
\mathrm{I}_{2 \mathrm{it}}=\alpha_{\mathrm{o}}+\alpha_{\mathrm{I}} \mathrm{P}_{\mathrm{it}}+\alpha_{2} \mathrm{H}_{\mathrm{it}}+\alpha_{3} \mathrm{~L}_{\mathrm{it}}+\varepsilon_{\mathrm{it}}(\mathrm{I} 6)
$$

Higher values of $\mathrm{I}_{2 \mathrm{it}}$ are associated with higher search intensity. Accordingly, equation (I6) is estimated using ordinal logistic regression.

Table (2) of the appendix shows the results of ordinal logistic regression of the job search intensity equation. The likelihood ratio chi-square shows that the overall model fit is good. All coefficient estimates are significant at the $\mathrm{i} \%$ level, except for living in Greater Cairo.

The results show that age, education, wealth, household characteristics, and region affect the job search intensity.

Concerning personal characteristics: First, age: the results assert again that women (15-39) are the most active in the job search. The parameter estimates for women younger than $4 \mathrm{O}$ is positive, except for those younger than I5. Again, the relationship between age and job search intensity is inverse $U$ shaped. The odds ratio for women aged 30-39 is higher than for women aged 15-29. Second, educational level: women's education positively affects not only job search propensity but also job search intensity. Unemployed women who have completed secondary education tend to search for work more intensively than the unemployed women without such education. Third, unemployed women with previous work experience search more intensively than those with no work experience. Those who have worked before are usually in more need to find new work, so as to compensate for the decrease in their income and to keep their standard of living from deteriorating. They have more incentive to search for work, and they are well informed about the labor market and search methods. 
Concerning household characteristics: First, wealth: unemployed females from wealthier households do a more intense job search. Second: concerning household size, although household size negatively affects job search propensity due to the more domestic responsibilities for women in large households, when they search they tend to search intensively. The women in big households who decided to search for a job are expected to be in more need of a job, and thus they search more intensively. Third, a higher independency ratio results in a more intense job search. Fourth, married women search more intensively than unmarried women. Although women who are the heads of their households have a higher job search propensity, considering Ira (including registering in a government employment office), their job search intensity is lower.

Concerning labor market characteristics; when the unemployment rate is higher, women search more intensively, especially in the Alexandria and Suez Canal governorates.

\subsubsection{Determinants of Women's Job Search Methods}

\subsubsection{Using both Formal and Informal Search Methods $\left(I_{3}\right)$}

$\mathrm{I}_{3}$ measures the use of both types of search methods; formal and informal search methods. Determinants of $\mathrm{I}_{3}$ include personal, household characteristics and labor market conditions (equation ${ }_{17}$ ). As $\mathrm{I}_{2}, \mathrm{I}_{3}$ is an ordinal qualitative variable. Thus, equation (I7) is estimated using ordinal logistic regression.

$$
\mathrm{I}_{3 \mathrm{it}}=\alpha_{\mathrm{o}}+\alpha_{\mathrm{I}} \mathrm{P}_{\mathrm{it}}+\alpha_{2} \mathrm{H}_{\mathrm{it}}+\alpha_{3} \mathrm{~L}_{\mathrm{it}}+\varepsilon_{\mathrm{it}}(\mathrm{I} 7)
$$

Table (3) of the appendix shows the results of ordinal logistic regression of equation ( $\mathrm{I} 7$ ). The likelihood ratio chi-square shows that the overall model fit is good. All coefficient estimates are significant at the $\mathrm{i} \%$ level.

Personal characteristics significantly affect $\mathrm{I}_{3}$. Unemployed women aged $30^{-} 39$, women with secondary education and above, and those with previous work experience are more active in their job search than younger and older women, women with less than secondary education and those without previous work experience.

Unemployed women from wealthier households are more likely to use both types of methods. Women belonging to larger households and those living in households with low dependency ratios are less likely to use two types of search methods. Women who are not heads of households and unmarried women are more likely to use both types of methods.

Living in regions with high unemployment rates results in increasing the probability of using both types of search methods. 


\subsubsection{Differences in Job Search Strategies}

To investigate determinants of differences in job search strategies used, six equations are estimated.

$$
\mathrm{M}_{\mathrm{it}}=\alpha_{\mathrm{o}}+\alpha_{\mathrm{I}} \mathrm{P}_{\mathrm{it}}+\alpha_{2} \mathrm{H}_{\mathrm{it}}+\alpha_{3} \mathrm{~L}_{\mathrm{it}}+\varepsilon_{\mathrm{it}} \text { (I8) }
$$

Where: $M_{i t}=I$ if method $M$ is used by individual $i$ and $M_{i t}=0$ if this method was not used by this individual. As $M_{i t}$ is a dichotomous indicator, the binary logistic model is used for estimation. Where:

Mr: using a formal method

M2: using a formal method, excluding registering in a government employment office

M3: using only a formal method

M4: depending only on registering in a government employment office as a sole job search method.

M5: using an informal method

M6: using only an informal method

The results in table (4) of the appendix illustrate the significant effect of personal and household characteristic in addition to labor market conditions on job search strategies used.

Women aged 15-39, are more likely than younger and older women to use a formal method, even if registering in a government employment office is excluded. The same result applies to using an informal method. However, all women less than 40 are more active in their job search than those aged 40 and above as they are less likely to depend only on one type of method, neither formal nor informal. However, women aged 30-39 may depend only on registering in a government employment office.

Education has been found to significantly affect women's job search strategies in Egypt. There is a significant difference in job search strategies between women with less than secondary education and those with secondary education and above. Women with secondary education and above are more likely to use formal search methods while those with less than secondary education are more likely to use informal methods. Higher educated women are actually more qualified to use formal methods. It is worth mentioning that in the case of depending on one type of search method; less educated women are more likely than higher educated ones to depend on informal search methods, as they are less likely to have access to formal methods. On the other hand, higher educated females are more likely to depend only on formal methods, especially registering in a government employment office. This raises concerns about dependency of educated women in Egypt on the government in their job search and the need to break this dependency. 
Previous work experience significantly affects women's job search strategies. Women with previous work experience are not only more active in their job search than those without previous work experience; they are also more likely to use informal search methods, and even depend only on them. They are expected to build social contacts that are useful in finding a new job during their previous work, while women without previous work experience lack access to such contacts. There is no significant effect of previous work experience on using a formal method. Previous work experience has a significant positive effect on using formal methods excluding registering in a government employment office. In addition, women without previous work experience are more likely to depend on formal methods only, especially registering in a government employment office.

Women from wealthier households are more likely to use formal search methods and to depend only on these methods, including registering in a government employment office while they are less likely to depend only on informal search methods. However, there is no significant effect of wealth on using informal methods; all groups, whether poor or rich, have their own social contacts.

Women living in larger households, are less likely to search for jobs, however when they do, they search more intensively because when they do, they are expected to be in need of a job. They are more likely to use formal methods excluding registering in a government employment office and they are less likely to depend only on formal methods in general, nor on registering in a government office. They are less dependent on the government in their job search. When they search, they are under pressure, so they can not afford waiting for a government job. They are less likely to depend on informal methods.

A lower dependency ratio indicates lower need to work, and thus less active job search. The lower the dependency ratio is, the less likely for unemployed females to use both formal and informal methods and the more likely to depend only on informal or formal methods, or to depend on registering in a government employment office only.

Unmarried women are less likely to use formal methods than married ones and are more likely to use informal methods and even to depend only on them. They are less likely than married women to depend only on formal methods or just to register in a government employment office.

Those who are not heads of their households are more likely than females who are to use formal search methods, but they are less likely to depend only on one type of method. However, being a head of the household has no significant effect on using informal methods. 
Unemployed women living in regions where the unemployment is higher are more likely to use both formal and informal search methods. However, they are less likely to depend on one type of these methods. The odds of depending on registering in a government employment office as a sole search method for unemployed women living in Alexandria and Suez Canal governorates is ceteris paribus only 0.53 times as likely as for unemployed females living in rural Upper Egypt. However, women living in other regions excluding urban Lower Egypt are more likely to depend only on this method in spite of the fact that they experience higher unemployment rates than in rural Upper Egypt. Women in rural areas and especially in Upper Egypt are less likely to get a job in the government.

\subsubsection{Determinants of Internet Job Search}

Internet job search is one of the important new search methods. Personal characteristics have significant effects on using the Internet for job search as complementary to traditional search methods among unemployed women as shown by results in Table(6) of the appendix.

Women aged $2 \mathrm{I}^{-} 45$ are more active than those less than 20 in using the Internet to search for jobs. Those entering the labor market before 20 are more likely to be less educated and thus unqualified to use the Internet in their job search.

The less educated are less able to use this method; in addition they are more likely to search for jobs that the Internet will not help them in finding.

Females without previous work experience are more likely to use the Internet in their job search as they are less informed about the labor market and lack access to useful social contacts, unlike unemployed women with previous work experience.

Women in urban areas where there is better access to the Internet and where women are higher educated are more likely to use the Internet in their job search.

\subsection{Determinants of Job Search Efficiency Index}

According to the JSEI and JSE2, women were classified in two groups: low JSE $=0$, high JSE $=\mathrm{I}$, the cut point is the average value of JSE. As it is a dichotomous indicator, the binary logistic model is used for estimation.

Results in tables $(5)$ and $(7)$ of the appendix assert the previous results reached:

Women aged $15^{-39}$ are more active in the job search than younger and older women. Among women aged 15-39, the youth (15-29) are less active than those aged 30-39. Women with a higher education level and those 
with previous work experience are more active than less educated women and those without previous work experience.

Women from wealthier families, unmarried women, women living in smaller households, women who are not heads of their households, and those living in households with a high dependency ratio are more active in the job search.

Women living in regions where the unemployment rate is higher are more active in their job search.

\section{Conclusions}

Job search is a vital activity in the labor market. It is more important now than ever to raise job search intensity and improve job search effectiveness for women, if unemployment in Egypt is not to become more concentrated among women. However, there is insufficient empirical information on job search behavior in Egypt. This study evaluates the difference between male and female job search behavior in the Egyptian labor market, the changes in this behavior between 1998 and 2006, to examine the effect of transition toward a market-oriented economy away from the public sector employment guarantee on job search activity, and finally examines determinants of women's job search behavior. The empirical analysis is based on two data sets; ELMS 98 and ELMPS 06.

The results show that between 1998 and 2006, the unemployed tended to be more active in their job search. However, this increase hides gender differences in job search. The results reveal three alarming facts that raise worries about women in the Egyptian labor market and also about their future labor market outcomes. Women were less active job searchers than men in 1998 and in 2006. Moreover, the job search gender gap has widened between 1998 and 2006. This gender gap is wider among unemployed youth than among all the unemployed. This gap is even wider if excluding registration in government employment offices from job search methods used. Women are not only less active in the job search, but they are also still more dependent on the government to find work. This increases the need to focus on enhancing job search efficiency of women.

Analyzing the reasons behind not doing a job search among unemployed men and women shows that pessimism about labor market conditions has been the most influential reason behind not doing a job search; it is more influential among women than among men, among young unemployed women than among all unemployed women. This is expected due to the transformation in the labor market and the lack of work opportunities 
in both the government and the public sector, where women, especially educated women used to find work of what they consider of a relatively good quality. Raising job quality in the private sector, ensuring enforcement of the labor law, forcing contracts and strong supervision is needed to make women, especially young women, more optimistic about jobs in the labor market.

In addition, in spite of all governmental and non-governmental efforts to promote entrepreneurship especially among youth, establishing private projects as a method to escape unemployment, is still very limited, especially among women. This raises questions about the effectiveness of these efforts especially in addressing female youth and also about the suitability of the investment climate in Egypt for MSMEs.

It is worth mentioning that one of the main reasons behind less active job searches is the lack of institutional support resulting in lack of awareness about job search methods that may be used and formal labor market intermediaries. Lack of awareness about job search methods is higher among youth. This raises questions about labor market institutions in Egypt, especially labor market intermediaries. The role of labor market intermediaries is not obvious for unemployed job searchers, especially among unemployed youth. Surprisingly, there is still a percentage of females waiting to be hired by the Ministry of Manpower. This percentage is even higher among female youth. There is an urgent need to support female job search through providing more information about other job search methods and how to use them, and strengthening the role of labor market intermediaries. Providing such support especially for educated women through schools and universities may be helpful.

Analyzing job search methods used in 1998 and 2006 by both men and women reveals a major labor market distortion in Egypt. This distortion is three dimensional. The unemployed, even among youth still depend on registering in a government office to find a job in spite of the fact that it is well known that the public sector employment guarantee has actually come to an end more than two decades ago. Informal methods are still the predominant job search methods used. Formal search methods other than registering in the government depend mainly on contacting employers directly. Non-governmental labor market intermediaries still play a small role in the Egyptian labor market in spite of the fact that this role has increased between 1998 and 2006. Transforming to a market economy where the private sector plays the leading role in providing employment where job seekers should conduct an intense job search has not been accompanied with the necessary transformation in labor market institutions. There is a need to strengthen the role of private formal labor market intermediaries in the Egyptian labor market. Work of private 
employment offices should be organized and then promoted among job seekers especially among the unemployed youth.

Using new methods as complementary to traditional job search methods is still very limited among the unemployed job searchers, especially among women. However, Internet job search should be organized so as to avoid adverse selection.

Analyzing determinants of women's job search behavior reveals a significant effect of personal, household characteristics and labor market conditions. Personal characteristics that determine job search behavior include age, education, and previous work experience. There is an inverse $\mathrm{U}$-shaped relationship between age and female job search. Women aged I5-39 are more active in job search than younger and older women. Among women aged $15^{-39}$, the youth $\left(5^{-29}\right)$ are less active than those aged $30^{-}$ 39. Education and previous work experience positively affect female job search. Household characteristics that determine job search behavior include household economic conditions, the dependency ratio, and marital status. Women from wealthier families, unmarried women, and those living in households with a high dependency ratio are more active in their job search. Finally, higher unemployment rates in the labor market result in a more active job search.

Searching for jobs is an important activity; however on-the-job search is not less important than off-the-job search. Off-the-job-search is necessary for the unemployed to leave unemployment. On-the-job search is conducted by the employed to improve their career prospects. There is a need for data on on-the-job search in Egypt to have a better picture about job search efforts and gender gap. In a labor market dominated by the private sector, on-the-job search plays a significant role in determining and enhancing labor market outcomes. 


\section{References}

Addison, John T., and Pedro Portugal. 200I. "Job Search Methods and Outcomes." IZA Discussion Paper 349. Bonn: The Institute for the Study of Labor.

Antoninis, Manos. 2004. "The Wage Effects from the Use of Personal Contacts as Hiring Channels." CSAE Working Paper Series 3. Oxford: Centre for the Study of African Economies.

Assaad, Ragui. 2007. "Labor Supply, Employment and Unemployment in the Egyptian Economy, 1998-2006." Working Paper Series 070r. Cairo: Economic Research Forum.

.2009. "Labor Supply, Employment, and Unemployment in the Egyptian Economy, I988-2006." In The Egyptian Labor Market Revisited, edited by Ragui Assaad, I-52. Cairo: The American University in Cairo Press.

Autor, David. 200I. "Wiring the Labor Market." Fournal of Economic Perspectives $15(\mathrm{I}): 25^{-} 40$.

--. 2008. "The Economics of Labor Market Intermediation: An Analytic Framework." Discussion Paper Series 3705. Bonn: Institute for the Study of Labor.

Azmat, Ghazala, Maia Güell, and Alan Manning. 2004. "Gender Gaps in Unemployment Rates in OECD Countries." Discussion Papers 4307. London: Center for Economic Policy Research.

Baker, Dean, Andrew Glyn, David Howell, and John Schmitt. 2004. Unemployment and Labor Market Institutions: The Failure of the Empirical Case for Deregulation. Accessed January 30, 20IO, from http:// www.newschool.edu/scepa/research/papers/EmploymentProtection_ UnemploymentEmpiricalCaseForDeregulation.pdf

Barron, John, and Otis Gilley. I98r. "Job Search and Vacancy Contacts: A Note." American Economic Reviere 71: 747-52.

Barron, John, and W. Mellow. 1979. "Search Effort in the Labor Market." Fournal of Human Resources I4: 389-404.

Barsoum, Ghada. 2007. "Egypt Labor Market Panel Survey 2006: Report on Methodology and Data Collection." Working Paper Series 0704. Cairo: Economic Research Forum.

Bayer, Patrick, Stephen Ross, and Giorgio Topa. 2005. "Place of Work and Place of Residence: Informal Hiring Networks and Labor Market Outcomes." NBER Working Paper Series IIOI9. Cambridge: National Bureau of Economic Research.

Bentolila, Samuel, Claudia Michelacci, and Javier Suarez. 2004. "Social Networks and Occupational Choice." CEPR Discussion Paper 4308. London: Center for Economic Policy Research. 
Bergemann, Annette, and Gerard J. van den Berg. 2006. "Active Labor Market Policy Effects for Women in Europe: A Survey." IZA Discussion Paper Series 2365. Bonn: Institute for the Study of Labor.

Bergin, Adele. 2009. Job Mobility in Ireland. The Economic and Social Review 4O (I): 15-47.

Berument, Hakan, Nukhet Dogan, and Aysit Tansel. 2006. "Unemployment: Evidence from an Emerging Economy." International Fournal of Manpower 27(7): 604-23.

Blau, David M., and Philip K. Robins. 1990. "Job Search Outcomes for the Employed and Unemployed." Fournal of Political Economy 98: 637-55.

Bloemen, Hans G. 2005. "Job Search, Search Intensity and Labour Market Transitions: An Empirical Analysis." Fournal of Human Resources XL (I): $232-69$.

Böheim, René, and Mark P. Taylor. 2002. "Job Search Methods, Intensity and Success in Britain in the I990s." Working Paper 0206. Linz: Department Of Economics, Johannes Kepler University of Linz.

Boman, Anders. 2008. "They Seek It Here, They Seek it There, They Seek It Everywhere. But Where Is Employment Found?" Working Papers in Economics 336. Gothenburg: University of Gothenburg.

Bortnick, Steven M., and Michelle Hanison. 1992. "Job Search Methods and Results: Tracking the Unemployed, I99I." Montbly Labor Review II5 (I2): $29^{-} 35$.

Bowen, Lindsey, and Jennifer Doyle. 2004. "Gender Differences in Employed Job Search." Issues in Political Economy I3.

Brown, Sarah, and Karl Taylor. 2008. "Reservation Wages, Expected Wages and Labour Market Outcomes: Analysis of Individual Level Panel Data." Sheffield Economic Research Paper Series 8. Sheffield: Department of Economics, University of Sheffield.

Bureau of Labor Statistics (BLS). 2008. Occupational Outlook Handbook, 2008-09 Edition. Accessed April 25, 2008, from http://www.bls. gov/oco/oco2OO42.htm.

Campbell, Karen E. 1988. "Gender Differences in Job-Related Networks." Work and Occupation 15 (2): 179-200.

CAPMAS. 2008. Census 2006. Cairo.

Chapple, Karen. 2006. "Overcoming Mismatch beyond Dispersal, Mobility and Development Strategies." Fournal of the American Planning Association 72 (3): 322-36.

Chirinko, Robert. 1982. "An Empirical Investigation of the Returns to Job Search." American Economic Review 72: 498-50I.

Eichhorst, Werner, and Michael Feil, Christoph Braun. 2008a. "Assessing Labor Market Institutions and Indicators - What Have We Learned?" IAB Discussion Paper 22. Nuremberg: The Institute of Employment Research of the German Federal Employment Agency. 
Eichhorst, Werner, and Regina Konle-Seidl. 2008b. "Contingent Convergence: A Comparative Analysis of Activation Policies." IZA Discussion Paper Series 3905. Bonn: Institute for the Study of Labor.

Eriksson, Stefan and Jonas Lagerström. 2008. "The Labor Market Consequences of Gender Differences in Job Search." Working Paper Io. Uppsala: Department of Economics - Uppsala University.

Eriksson, Tor, Reija Lilja, and Hege Torp. 2002. "Determinants of Job Search Intensity - Some Evidence from the Nordic Countries." Discussion Paper 185. Helsinki: Labor Institute for Economic Research.

Fahr, Rene', and Hilmar Schneider. 2004. Comparison Study of Job Turnover and Job Search Methods between Japan and Europe. A Report prepared for RIETI, Tokyo. Accessed April 30, 2009, from http://www.rieti. go.jp/jp/publications/dp/o4jo36_iza.pdf

Fischer, Claude S., and Stacey J. Oliker. 1983. "A Research Note on Friendship and the Life Cycle." Social Forces 62: 124-32.

Fountain, Christine. 2005. "Finding a Job in the Internet Age." Social Forces 83 (3): 1235-62.

Freeman, Richard B. 2008. "Labor Market Institutions around the World." CEP Discussion Paper 844. London: Center for Economic Performance.

Gaure, Simen, Knut Røed, and Lars Westlie .2008. "The Impacts of Labor Market Policies on Job Search Behavior and Post-Unemployment Job Quality." Discussion Paper Series 3802 . Bonn: Institute for the Study of Labor.

Gautier, Pieter A., José Luis Moraga-González, and Ronald P. Wolthoff. 2007. "Structural Estimation of Search Intensity: Do Non-Employed Workers Search Enough?" Tinbergen Institute Discussion Paper TI 071/3. Amsterdam: Tinbergen Institute.

Granovetter, Mark. 1974. Getting a Fob: A Study of Contacts and Careers. Cambridge: Harvard University Press.

Green, Colin. 2009. "Short Term Gain, Long Term Pain-The Effect of Informal Job Search Methods on Post-Displacement Outcomes." LUMS Working Papers Series II. Lancaster: Lancaster University Management School-Department of Economics.

Gregg, Paul, and Jonathan Wadsworth. 1996. "How Effective are State Employment Agencies? Job Centre Use and Job Matching in Britain.” Oxford Bulletin of Economics and Statistic 58:443-67.

Ham John, Jan Svejnar, and Katherine Terrell. 1998. "Unemployment, the Social Safety Net and Efficiency during Transition: Evidence from Micro Data on Czech and Slovak Men." American Economic Review 88 (5): III7-42.

Hashimoto, Masanori. 2004. "Unemployed Workers and Job Search Methods in the United States." Discussion Paper 04-J-036. Tokyo: Research Institute of Economy, Trade \& Industry.

Heckman, James. 1979. "Sample Selection Bias as a Specification Error." Econometrica 47(I): 153-I6I. 
Hinnosaar, Marit. 2004. "Reservation Wage, Job Search Intensity and Unemployment Benefits." Kroon \& Economy I. Tallinn: Bank of Estonia.

Holzer, Harry J. 1988. "Search Method Use by Unemployed Youth." Fournal of Econometric Literature 6: 1-20.

ILO. 2009a. Global Employment Trends. Geneva: International Labor Organization.

ILO. 2009b. Global Employment Trends - Update. Geneva: International Labor Organization.

ILO. 2008. Youth Employment: Breaking Gender Barriers for Young Women and Men. Geneva: International Labor Organization.

Kahn, Lawrence, and Stuart Low. 1988. "Systematic and Random Search: A Synthesis." Fournal of Human Resources 23(I): $\mathrm{I}-2 \mathrm{O}$.

Kanfer, Ruth, Connie Wanberg, and Tracy Kantrowitz. 200I. "Job Search and Employment: A Personality-Motivational Analysis and Meta-Analytic Review." Fournal of Applied Psychology 86: 837-55.

Katz, Lawrence, and Bruce Meyer. 1988. "The Impact of the Potential Duration of Unemployment Benefits on the Duration of Unemployment." NBER Working Paper Series 274I. Cambridge: National Bureau of Economic Research.

Khan, Lawrence. 2009. "Temporary Jobs and Job Search Effort in Europe." IZA Discussion Paper Series 4020. Bonn: Institute for the Study of Labor.

Kluve, Jochen et al. 2007. Active Labor Market PoliciesinEurope-Performance and Perspectives. Berlin: Springer.

Kondylis, Florence, and Marco Manacorda. 2006. "Youths in the Labor Market and Transition from School to Work in Tanzania." SP Discussion Paper 0606. Washington D.C: WB- the Social Protection Unit.

Koning, Pierre, Gerard J. van den Berg, and Geert Ridder. I997. "A Structural Analysis of Job Search Methods and Subsequent Wages." Research Memorandum 36. Amsterdam: University of Amsterdam.

Konle-Seidl, Regina, Werner Eichhorst, and Maria GrienbergerZingerle. 2007. "Activation Policies in Germany from Status Protection to Basic Income Support." IAB Discussion Paper 6. Nuremberg: The Institute of Employment Research of the German Federal Employment Agency.

Krueger, Alan B., and Andreas Mueller. 2008. "Job Search and Unemployment Insurance: New Evidence from Time Use Data." IZA Discussion Paper Series 3667. Bonn: Institute for the Study of Labor.

Kucel, Aleksander, and Delma Byrne. 2008. "Are Over-educated People Insiders or Outsiders? A Case of Job Search Methods and Over-education in UK." ESRI Working Paper 258. Barcelona: Pompeu Fabra University, Department of Political and Social Sciences.

Kuhn, Peter, and Mikal Skuterud. 2002. "Job Search Methods: Internet versus Traditional." Monthly Labor Review I25 (IO): $3^{-}$II. 
Kuhn, Peter, and Mikal Skuterud. 2004. "Internet Job Search and Unemployment Durations." The American Economic Review 94 (I): 218-32.

Lemaitre, Georges. 1992. "The Measurement of Job Search and Unemployment in a Retrospective Setting." Income Research Paper Series 4. Ottawa: Income Statistics Canada.

Lindeboom, Maarten, Jan Van Ours, and Gusta Renes. 1994. "Matching Employers and Workers: An Empirical Analysis of the Effectiveness of Search." Oxford Economic Papers 46(I): 45-67.

Ljungqvist, Lars, and Thomas J. Sargent. 1995. "Welfare States and Unemployment." Economic Theory 6: I43 60.

Loury, Linda D. 2006. "Job Search among Informal Contacts." Discussion Papers Series 0604. Medford: Department of Economics, Tufts University.

Lubyova, Martina, and Jan van Ours. 1997. "Unemployment Dynamics and the Restructuring of the Slovak Unemployment Benefit System." European Economic Review 4I(3-5): 925-34.

Margolis, David N., and Véronique Simonnet. 2003. "Educational Track, Networks and Labor Market Outcomes." IZA Discussion Paper Series 699. Bonn: Institute for the Study of Labor.

Márquez, Gustavo, and Cristóbal Ruiz-Tagle. 2004. "Search Methods and Outcomes in Developing Countries: The Case of Venezuela." Working Paper 519. Washington D.C.: Inter-American Development Bank.

Masagué, Ana Carolina Ortega. 2008. "Gender gaps in unemployment rates in Argentina." Económica, La Plata LIV (I-2): 16I-202.

McDonald, Steve, and Glen H. Elder. 2006. "When Does Social Capital Matter? Non-Searching for Jobs across the Life Course." Social Forces 85 (I): $52 \mathrm{I}^{-} 49$.

McQuaid, Ronald W. 2006. "Job Search Success and Employability in Local Labor Markets." Annals of Regional Science 4O: 4O7-2I.

McQuaid, Ronald W., and Colin Lindsay. 2005. "The Concept of Employability." Urban Studies 42 (2): 197-219.

Micklewright, John, and Gyula Nagy. 1999. "The Informational Value of Job Search Data and the Dynamics of Search Behaviour: Evidence from Hungary." Budapest Working Papers on the Labour Market I. Budapest: Institute of Economics of Hungarian Academy of Sciences.

Mitra, Sophie. 2007. "The Reservation Wages of Social Security Disability Insurance Beneficiaries." Social Security Bulletin 67(4): 89-III.

Moore, Gwen. I990. "Structural Determinants of Men's and Women's Personal Networks." American Sociological Review 55: 726-35.

Nasser, Ramzi Naim, and Kamal Abouchedid. 2006. "Job-Seeking Behavior and Job Outcomes among Lebanese University Graduates in Private and Public Universities." International fournal for Educational and Vocational Guidance 6:167-80. 
Orazem, Peter F., James D. Werbel, and James C. Mcelroy. 2003. "Market Expectations, Job Search, and Gender Differences in Starting Pay." Fournal of Labor Research 24(2): 307-2I.

Osberg, Lars. 1993. "Fishing in Different Pools: Job-Search Strategies and Job-Finding Success in Canada in the Early I980s." Fournal of Labor Economics II:348-86.

Paik, Myungho. 2008. "Gender Differences in Demography and Labor Markets." PhD diss., University of Texas at Austin.

Perugini, Cristiano, and Marcello Signorelli. 2007. "Determinants of Unemployment Differentials and Dynamics across EU-I5 Countries and Regions." Paper presented at the European Association for Comparative Economics Studies (EACES) 9th Bi-Annual Conference: Development Strategies - A Comparative View, Brighton, September 8-ıо.

Ponzo, Michela, and Vincenzo Scoppa. 2008. "The Use of Informal Networks in Italian Labor Markets: Efficiency or Favoritisms?" MPRA Paper II764. Munich: Munich University Library.

Rees, Albert. 1966. "Information Networks in Labuor Markets." American Economic Review 56: 59-66.

Rones, Philip L. I983. "The Labor Market Problems of Older Workers." Monthly Labor Reviere I06 (5): 3-I2.

Room, Tairi. 2004. "Search Intensity and Wage Differences." Bank of Estonia Working Papers I. Tallinn: Bank of Estonian.

Sabatier, Mareva. 2000. "Job Search Model with Endogenous Search Methods: An Application on Young Unemployment Spells in France." Paper presented at the $15^{\text {th }}$ Annual congress of the European Economic Association, Bozen-Bolzano, August 30 - September 2.

Sackey, Harry A., and Barfour Osei. 2006. "Human Resource Underutilization in an Era of Poverty Reduction: An Analysis of Unemployment and Underemployment in Ghana." African Development Reviere I8 (2): 22I-47.

Sagen, Bardley, Jerald Dallam, and John Laverty. 1999. "Job Search Techniques as Employment Channels: Differential Effects on the Initial Employment Success of College Graduates." The Career Development 2uarterly 84: 74-85.

Saks, Alan M., and Blake Ashforth. 2002. "Is Job Search Related to Employment Quality? It All Depends on Fit." Fournal of Applied Psychology 87: 646-54.

Salas-Velasco, Manuel. 2007. "The Transition from Higher Education to Employment in Europe: the Analysis of the Time to Obtain the First Job." Higher Education 54: 333-60.

Sestito, Paolo and Eliana Viviano. 2008. "Reservation Wages: Explaining Some Puzzling Regional Patterns.” Working Papers 696. Rome: Bank of Italy. 
Smirnova, Natalia. 2003. "Job Search Behavior of Unemployed in Russia." Discussion Paper 13. Hilsinki: Bank of Finland.

Smith, Stephen. 2003. Labour Economics. The $2^{\text {nd }}$ edition. London: Routledge.

Smits, Jeroen. 2003. Estimating the Heckman Two Step Procedure to Control for Selection Bias with SPSS. Accessed January 20, 2010, from http://home.planet.nl/-smit9354/selbias/Heckman-SPSS.doc.

Stevenson, Bestsey. 2008. "The Internet and Job Search." NBER Working Paper Series 13886. Cambridge: NBER.

Stoll, Michael A., and Steven Raphael. 2000. "Racial Differences in Spatial Job Search Patterns: Exploring the Causes and Consequences." Economic Geography 76 (3): 201-23.

Straits, B.C. 1998. "Occupational Sex Segregation: The Role of Personal Ties." Fournal of Vocational Behavior 52 (2): 19I-207.

Tansel, Aysit. 2002. "Economic Development and Female Labor Force Participation in Turkey: Time-series Evidence and Cross-province Estimates." ERC Working Papers in Economics or/05. Ankara: Economic Research Center.

Tasci, Mehmet. 2008. Job Search and Determinants of Job Search Intensity in Turkey. Balikesir: Balikesir University. Accessed December 15, 2009, from http://papers.ssrn.com/sol3/papers.cfm?abstract_id=I082715

Van Hooft, Edwin A.J., Marise Ph. Born, Toon W. Taris, and Henk van der Flier. 2005. "Predictors and Outcomes of Job Search Behavior: The Moderating Effects of Gender and Family Situation." Fournal of Vocational Bebavior 67 (2): 133-52.

Wahba, Jackline, and Yves Zenou. 2005. "Density, Social Networks and Job Search Methods: Theory and Application to Egypt." fournal of Development Economics 78 (2): 443-73.

Weber, Andrea, and Helmut Mahringer. 2002. "Choice and Success of Job Search Methods." Economic Series I25. Vienna: Institute for Advanced Studies.

Werbel, James D. 2000. "Relationships among Career Exploration, Job Search Intensity, and Job Search Effectiveness in Graduating College Students." Fournal of Vocational Behavior 57: 379-94.

Woltermann, Silke. 2002. "Job-Search Methods and Labor Market Transitions in a Segmented Economy - Some Empirical Evidence from Brazil.” Working Paper 88. Göttingen: Ibero-America Institute for Economic Research.

Yankow, Jeffrey J. 2009. "Some Empirical Evidence of the Efficacy of Job Matching in Urban Labor Markets." International Advances in Economic Research 15: 233-44.

Zaretsky, Adam M., and Cletus C. Coughlin. 1995. "An Introduction to the Theory and Estimation of a Job-Search Model." Review 77 (I): 53-68. 


\section{Annex}

\section{Summary of Models Estimated}

Table (1) - Job Search Propensity

A-(Probability Modeled Search=1)

\begin{tabular}{|l|c|c|c|}
\hline \multirow{2}{*}{ Explanatory Variable } & \multicolumn{3}{|c|}{ I1a } \\
\cline { 2 - 4 } & $\begin{array}{c}\text { Estimate } \\
\text { (B) }\end{array}$ & S.E. & Odds Ratio \\
\hline Intercept & 8.6 & 0.23 & \\
\hline Age (reference category: 40+) & & & \\
\hline Age (1) <15 & -6.3 & 1.3 & 0.002 \\
\hline Age (2) 15-29 & 0.75 & 0.02 & 2.118 \\
\hline Age (3) 30-39 & 1.28 & 0.02 & 3.608 \\
\hline $\begin{array}{l}\text { Education (reference category: secondary and } \\
\text { above) }\end{array}$ & & & \\
\hline Educational Level: below secondary & -0.27 & 0.018 & 0.760 \\
\hline $\begin{array}{l}\text { Ever Worked Before (reference category: never } \\
\text { worked before) }\end{array}$ & -0.12 & 0.010 & 0.988 \\
\hline Wealth & 0.30 & 0.003 & 1.344 \\
\hline Household Size Likelihood Ratio Chi-square & -0.064 & 0.001 & 0.938 \\
\hline 1/dependency ratio & -1.46 & 0.017 & 0.233 \\
\hline Head (reference category: head) & & & \\
\hline Not Head & -6.05 & 0.230 & 0.002 \\
\hline Region: reference category (Rural Upper Egypt) & & & \\
\hline Region (1)-Greater Cairo & -0.51 & 0.009 & 0.600 \\
\hline Region (2) - Alex and Suez Canal & 3.15 & 0.031 & 23.254 \\
\hline Region (3) - Urban Lower Egypt & 0.21 & 0.009 & 1.24 \\
\hline Region (4) -Urban Upper Egypt & -0.36 & 0.010 & 0.70 \\
\hline Region (5) - Rural Lower Egypt & 0.50 & 0.008 & 1.641 \\
\hline Marriage (reference category: married) & & & \\
\hline Not Married & -0.238 & 0.006 & 0.788 \\
\hline Selection Term & -0.762 & 0.009 & 0.467 \\
\hline & & 725 \\
\\
\hline
\end{tabular}

- All Estimates are significant at the 1\% significance level. 
B- Job Search Propensity - Excluding Registering

in a Government Employment Office - (Probability Modeled Search=1)

\begin{tabular}{|l|c|c|c|}
\hline \multirow{2}{*}{ Explanatory Variable } & \multicolumn{3}{|c|}{ I1b } \\
\cline { 2 - 4 } & $\begin{array}{c}\text { Estimate } \\
\text { (B) }\end{array}$ & S.E. & 0dds Ratio \\
\hline Intercept & 1.39 & 0.022 & \\
\hline Age (reference category: 40+) & & & \\
\hline Age (1) <15 & -3.98 & 0.290 & 0.019 \\
\hline Age (2) 15-29 & 0.64 & 0.016 & 1.89 \\
\hline Age (3) 30-39 & 0.65 & 0.017 & 1.92 \\
\hline $\begin{array}{l}\text { Education (reference category: secondary } \\
\text { and above) }\end{array}$ & & & \\
\hline Educational Level: below secondary & -0.233 & 0.016 & 0.793 \\
\hline $\begin{array}{l}\text { Ever Worked Before (reference category: } \\
\text { never worked before) }\end{array}$ & 0.357 & 0.009 & 1.43 \\
\hline Wealth & 0.174 & 0.003 & 1.19 \\
\hline Household Size & -0.004 & 0.001 & 0.996 \\
\hline 1/dependency ratio & -1.522 & 0.015 & 0.218 \\
\hline Head (reference category: head) & & & \\
\hline Not Head & 0.278 & 0.011 & 1.320 \\
\hline $\begin{array}{l}\text { Region: Reference Category (Rural Upper } \\
\text { Egypt) }\end{array}$ & & & \\
\hline Region (1) -Greater Cairo & -0.34 & 0.008 & 0.71 \\
\hline Region (2) - Alex and Suez Canal & 2.31 & 0.019 & 10.104 \\
\hline Region (3) - Urban Lower Egypt & 0.34 & 0.008 & 1.408 \\
\hline Region (4) - Urban Upper Egypt & -0.59 & 0.008 & 0.557 \\
\hline Region (5) - Rural Lower Egypt & 0.06 & 0.008 & 1.059 \\
\hline Marriage (reference category: married) & & & \\
\hline Not Married & -0.02 & 0.005 & 0.978 \\
\hline Selection Term & & 0.007 & 0.560 \\
\hline & & 725 & \\
\hline & & 103251.6 & \\
\hline & $<0.0001$ & \\
\hline
\end{tabular}

- All Estimates are significant at the $1 \%$ significance level. 
Table (2) - Job Search Intensity (12)

(Ordinal logistic estimation, probabilities modeled are of higher search intensity)

\begin{tabular}{|l|c|c|c|}
\hline \multirow{2}{*}{ Explanatory Variable } & \multicolumn{3}{|c|}{ I2 } \\
\cline { 2 - 4 } & $\begin{array}{c}\text { Estimate } \\
\text { (B) }\end{array}$ & S.E. & Odds Ratio \\
\hline Age (reference category: 40+) & & & \\
\hline Age (1) <15 & -24.9 & 0.000 & $1.5 \mathrm{E}-11$ \\
\hline Age (2) 15-29 & 0.513 & 0.013 & 1.67 \\
\hline Age (3) 30-39 & 0.837 & 0.014 & 2.31 \\
\hline $\begin{array}{l}\text { Education (reference category: secondary } \\
\text { and above) }\end{array}$ & & & \\
\hline Educational Level: below secondary & -0.06 & 0.012 & 0.94 \\
\hline $\begin{array}{l}\text { Ever Worked Before (reference category: } \\
\text { never worked before) }\end{array}$ & 0.286 & 0.006 & 1.33 \\
\hline Wealth & 0.178 & 0.002 & 1.19 \\
\hline Household Size & 0.02 & 0.001 & 1.02 \\
\hline 1/dependency ratio & -1.31 & 0.011 & 0.27 \\
\hline Head (reference category: head) & & & \\
\hline Not Head & 0.480 & 0.008 & 1.6 \\
\hline $\begin{array}{l}\text { Region: Reference Category (Rural Upper } \\
\text { Egypt) }\end{array}$ & & & \\
\hline Region (1)-Greater Cairo & -0.360 & 0.004 & 0.698 \\
\hline Region (2) - Alex and Suez Canal & -0.938 & 0.005 & 0.39 \\
\hline Region (3) - Urban Lower Egypt & & 725 & \\
\hline Region (4) - Urban Upper Egypt & 1.91 & 0.008 & 6.8 \\
\hline Region (5) - Rural Lower Egypt & 0.60 & 0.006 & 1.82 \\
\hline Marriage (reference category: married) & 0.02 & 0.007 & 1.02 \\
\hline Not Married & 0.4 & 0.005 & 1.49 \\
\hline Selection Term & & & \\
\hline & & $<0.0558 .1$ \\
\hline
\end{tabular}

- All Estimates are significant at the 1\% significance level, except for *. 
Table (3) - Using both Formal and Informal Methods (I3)

(Ordinal logistic estimation)

\begin{tabular}{|l|c|c|c|}
\hline \multirow{2}{*}{ Explanatory Variable } & \multicolumn{2}{|c|}{ I3 } \\
\cline { 2 - 4 } & $\begin{array}{c}\text { Estimate } \\
\text { (B) }\end{array}$ & S.E. & Odds Ratio \\
\hline Age (reference category: 40+) & & & \\
\hline Age (1) <15 & -25.4 & 0.000 & 9.3 E-12 \\
\hline Age (2) 15-29 & 1.22 & 0.014 & 3.387 \\
\hline Age (3) 30-39 & 1.50 & 0.02 & 4.482 \\
\hline $\begin{array}{l}\text { Education (reference category: secondary } \\
\text { and above) }\end{array}$ & & & \\
\hline Educational Level: below secondary & -0.389 & 0.013 & 0.678 \\
\hline $\begin{array}{l}\text { Ever Worked Before (reference category: } \\
\text { never worked before) }\end{array}$ & 0.53 & 0.01 & 1.699 \\
\hline Wealth & 0.133 & 0.002 & 1.142 \\
\hline Household Size & -0.03 & 0.001 & 0.97 \\
\hline 1/dependency ratio & -1.29 & 0.012 & 0.275 \\
\hline Head (reference category: head) & & & \\
\hline Not head & 0.19 & 0.01 & 1.209 \\
\hline $\begin{array}{l}\text { Region: Reference Category (Rural Upper } \\
\text { Egypt) }\end{array}$ & & & \\
\hline Region (1) - Greater Cairo & & & \\
\hline Region (2) - Alex and Suez Canal & 0.24 & 0.01 & 1.271 \\
\hline Region (3) - Urban Lower Egypt & 2.001 & 0.010 & 7.396 \\
\hline Region (4) - Urban Upper Egypt & 1.057 & 0.006 & 2.288 \\
\hline Region (5) - Rural Lower Egypt & -0.05 & 0.01 & 0.95 \\
\hline Marriage (reference category: married) & 0.731 & 0.01 & 2.077 \\
\hline Not Married & & & \\
\hline Selection Term & & 0.00 & 1.197 \\
\hline & & 0.006 & 0.758 \\
\hline
\end{tabular}

- All Estimates are significant at the 1\% significance level. 
Table (4) - Methods Used

(Probability Modeled Using Method $\mathrm{i}=1$ )

4-A. Using a Formal Method

\begin{tabular}{|l|c|c|c|}
\hline \multirow{2}{*}{ Explanatory Variable } & \multicolumn{3}{|c|}{ Formal } \\
\cline { 2 - 4 } & $\begin{array}{c}\text { Estimate } \\
\text { (B) }\end{array}$ & S.E. & Odds Ratio \\
\hline Intercept & 1.88 & 0.024 & \\
\hline Age (reference category: 40+) & & & \\
\hline Age (1) <15 & -2.37 & 0.29 & 0.09 \\
\hline Age (2) 15-29 & 0.84 & 0.02 & 2.31 \\
\hline Age (3) 30-39 & 1.54 & 0.02 & 4.7 \\
\hline $\begin{array}{l}\text { Education (reference category: secondary } \\
\text { and above) }\end{array}$ & & & \\
\hline Educational Level: below secondary & -0.43 & 0.02 & 0.654 \\
\hline $\begin{array}{l}\text { Ever Worked Before (reference category: } \\
\text { never worked before) }\end{array}$ & $-0.01^{*}$ & 0.01 & 0.995 \\
\hline Wealth & 0.35 & 0.003 & 1.4 \\
\hline Household Size & -0.033 & 0.001 & 0.97 \\
\hline 1/dependency ratio & -1.67 & 0.015 & 0.189 \\
\hline Head (reference category: head) & & & \\
\hline Not Head & 0.122 & 0.013 & 1.129 \\
\hline $\begin{array}{l}\text { Region: Reference Category (Rural Upper } \\
\text { Egypt) }\end{array}$ & & & \\
\hline Region (1) - Greater Cairo & & & \\
\hline Region (2) - Alex and Suez Canal & -0.427 & 0.01 & 0.653 \\
\hline Region (3) - Urban Lower Egypt & 1.85 & 0.015 & 6.34 \\
\hline Region (4) -Urban Upper Egypt & 0.41 & 0.01 & 1.51 \\
\hline Region (5) - Rural Lower Egypt & 0.21 & 0.01 & 1.24 \\
\hline Marriage (reference category: married) & 0.77 & 0.007 & 2.17 \\
\hline Not Married & & & \\
\hline Selection Term & -0.845 & 0.006 & 0.641 \\
\hline & & 0.008 & 0.442 \\
\hline
\end{tabular}

- All Estimates are significant at the 1\% significance level, except for *. 


\section{4-B. Using a Formal Method}

Excluding registering in a government employment office

\begin{tabular}{|l|c|c|c|}
\hline \multirow{2}{*}{ Explanatory Variable } & \multicolumn{3}{|c|}{ Formal } \\
\cline { 2 - 4 } & $\begin{array}{c}\text { Estimate } \\
\text { (B) }\end{array}$ & S.E. & Odds Ratio \\
\hline Intercept & 0.683 & 0.021 & \\
\hline Age (reference category: 40+) & & & \\
\hline Age (1) <15 & -2.816 & 0.290 & 0.060 \\
\hline Age (2) 15-29 & 0.638 & 0.016 & 1.893 \\
\hline Age (3) 30-39 & 0.898 & 0.017 & 2.454 \\
\hline $\begin{array}{l}\text { Education (reference category: secondary and } \\
\text { above) }\end{array}$ & & & \\
\hline Educational Level: below secondary & -0.328 & 0.015 & 0.720 \\
\hline $\begin{array}{l}\text { Ever Worked Before (reference category: never } \\
\text { worked before) }\end{array}$ & 0.197 & 0.01 & 1.22 \\
\hline Wealth & 0.258 & 0.003 & 1.295 \\
\hline Household Size & 0.018 & 0.001 & 1.018 \\
\hline 1/dependency ratio & -1.697 & 0.014 & 0.183 \\
\hline Head (reference category: head) & & & \\
\hline Not head & 0.809 & 0.010 & 2.245 \\
\hline Region: Reference Category (Rural Upper Egypt) & & & \\
\hline Region (1)-Greater Cairo & -0.252 & 0.008 & 0.777 \\
\hline Region (2) - Alex and Suez Canal & 1.513 & 0.012 & 4.540 \\
\hline Region (3) - Urban Lower Egypt & 0.270 & 0.007 & 1.310 \\
\hline Region (4) -Urban Upper Egypt & -0.169 & 0.008 & 0.845 \\
\hline Region (5) - Rural Lower Egypt & 0.218 & 0.006 & 1.244 \\
\hline Marriage (reference category: married) & & & \\
\hline Not Married & -0.310 & 0.005 & 0.733 \\
\hline Selection Term & -0.761 & 0.007 & 0.467 \\
\hline & & 725 & \\
\hline - & & 121179.3 \\
\\
\hline
\end{tabular}

- All Estimates are significant at the $1 \%$ significance level. 
4-C. Using a Formal Method Only

\begin{tabular}{|l|c|c|c|}
\hline \multirow{2}{*}{ Explanatory Variable } & \multicolumn{3}{|c|}{ Formal } \\
\cline { 2 - 4 } & $\begin{array}{c}\text { Estimate } \\
\text { (B) }\end{array}$ & S.E. & Odds Ratio \\
\hline Intercept & 1.831 & 0.022 & \\
\hline Age (reference category: 40+) & & & \\
\hline Age (1) <15 & -2.409 & 0.291 & 0.090 \\
\hline Age (2) 15-29 & -0.651 & 0.018 & 0.522 \\
\hline Age (3) 30-39 & -0.439 & 0.018 & 0.645 \\
\hline $\begin{array}{l}\text { Education (reference category: secondary } \\
\text { and above) }\end{array}$ & & & \\
\hline Educational Level: below secondary & -1.536 & 0.025 & 0.215 \\
\hline $\begin{array}{l}\text { Ever Worked Before (reference category: } \\
\text { never worked before) }\end{array}$ & -0.814 & 0.009 & 0.443 \\
\hline Wealth & 0.207 & 0.003 & 1.230 \\
\hline Household Size & -0.009 & 0.001 & 0.991 \\
\hline 1/dependency ratio & 0.046 & 0.014 & 1.047 \\
\hline Head (reference category: head) & & & \\
\hline Not Head & -0.432 & 0.010 & 0.649 \\
\hline $\begin{array}{l}\text { Region: Reference Category (Rural Upper } \\
\text { Egypt) }\end{array}$ & & & \\
\hline Region (1) - Greater Cairo & -1.159 & 0.008 & 0.314 \\
\hline Region (2) - Alex and Suez Canal & -1.301 & 0.011 & 0.272 \\
\hline Region (3) - Urban Lower Egypt & -1.183 & 0.008 & 0.306 \\
\hline Region (4) -Urban Upper Egypt & 0.055 & 0.008 & 1.056 \\
\hline Region (5) - Rural Lower Egypt & -0.345 & 0.006 & 0.709 \\
\hline Marriage (reference category: married) & & & \\
\hline Not Married & -0.592 & 0.005 & 0.553 \\
\hline Selection Term & -0.501 & 0.007 & 0.606 \\
\hline & & 725 & \\
\hline
\end{tabular}

- All Estimates are significant at the 1\% significance level. 
4-D. using "Registering in a government employment office" only

\begin{tabular}{|l|c|c|c|}
\hline \multirow{2}{*}{ Explanatory Variable } & \multicolumn{3}{|c|}{ Formal } \\
\cline { 2 - 4 } & $\begin{array}{c}\text { Estimate } \\
\text { (B) }\end{array}$ & S.E. & Odds Ratio \\
\hline Intercept & -1.592 & 0.035 & \\
\hline Age (reference category: 40+) & & & \\
\hline Age (1) <15 & -2.270 & 0.478 & 0.103 \\
\hline Age (2) 15-29 & -0.211 & 0.026 & 0.810 \\
\hline Age (3) 30-39 & 0.536 & 0.027 & 1.710 \\
\hline $\begin{array}{l}\text { Education (reference category: secondary } \\
\text { and above) }\end{array}$ & & & \\
\hline Educational Level: below secondary & -0.214 & 0.029 & 0.808 \\
\hline $\begin{array}{l}\text { Ever Worked Before (reference category: } \\
\text { never worked before) }\end{array}$ & -0.833 & 0.017 & 0.435 \\
\hline Wealth & 0.180 & 0.005 & 1.197 \\
\hline Household Size & -0.151 & 0.002 & 0.860 \\
\hline 1/dependency ratio & 1.065 & 0.025 & 2.901 \\
\hline Head (reference category: head) & & & \\
\hline Not Head & -1.121 & 0.013 & 0.326 \\
\hline $\begin{array}{l}\text { Region: Reference Category (Rural Upper } \\
\text { Egypt) }\end{array}$ & & & \\
\hline Region (1) - Greater Cairo & 0.122 & 0.017 & 1.130 \\
\hline Region (2) - Alex and Suez Canal & -0.632 & 0.026 & 0.531 \\
\hline Region (3) - Urban Lower Egypt & $-0.023^{*}$ & 0.017 & 0.977 \\
\hline Region (4) -Urban Upper Egypt & 1.200 & 0.016 & 3.319 \\
\hline Region (5) - Rural Lower Egypt & 1.079 & 0.014 & 2.942 \\
\hline Marriage (reference category: married) & & & \\
\hline Not Married & -0.268 & 0.009 & 0.765 \\
\hline Selection Term & 0.147 & 0.012 & 1.159 \\
\hline & & 725 \\
\hline
\end{tabular}

- All Estimates are significant at the $1 \%$ significance level, except for *. 
4-E. using an Informal Method

\begin{tabular}{|l|c|c|c|}
\hline \multirow{2}{*}{ Explanatory Variable } & \multicolumn{3}{|c|}{ Formal } \\
\cline { 2 - 4 } & $\begin{array}{c}\text { Estimate } \\
\text { (B) }\end{array}$ & S.E. & Odds Ratio \\
\hline Intercept & -1.619 & 0.022 & \\
\hline Age (reference category: 40+) & & & \\
\hline Age (1) <15 & -2.764 & 0.177 & 0.063 \\
\hline Age (2) 15-29 & 1.130 & 0.017 & 3.096 \\
\hline Age (3) 30-39 & 1.191 & 0.018 & 3.291 \\
\hline $\begin{array}{l}\text { Education (reference category: secondary } \\
\text { and above) }\end{array}$ & & & \\
\hline Educational Level: below secondary & 0.109 & 0.015 & 1.115 \\
\hline $\begin{array}{l}\text { Ever Worked Before (reference category: } \\
\text { never worked before) }\end{array}$ & 0.688 & 0.008 & 1.990 \\
\hline Wealth & $0.000^{*}$ & 0.003 & 1 \\
\hline Household Size & -0.026 & 0.001 & 0.974 \\
\hline 1/dependency ratio & -0.921 & 0.013 & 0.398 \\
\hline Head (reference category: head) & & & \\
\hline Not Head & $0.005^{*}$ & 0.009 & 1.005 \\
\hline $\begin{array}{l}\text { Region: Reference Category (Rural Upper } \\
\text { Egypt) }\end{array}$ & & & \\
\hline Region (1) - Greater Cairo & 0.651 & 0.007 & 1.918 \\
\hline Region (2) - Alex and Suez Canal & 2.027 & 0.011 & 7.594 \\
\hline Region (3) - Urban Lower Egypt & 1.173 & 0.007 & 3.233 \\
\hline Region (4) -Urban Upper Egypt & -0.278 & 0.008 & 0.758 \\
\hline Region (5) - Rural Lower Egypt & 0.600 & 0.006 & 1.823 \\
\hline Marriage (reference category: married) & & & \\
\hline Not Married & 0.404 & 0.005 & 1.497 \\
\hline Selection Term & 0.038 & 0.006 & 1.039 \\
\hline & & 725 & \\
\hline
\end{tabular}

- All Estimates are significant at the $1 \%$ significance level, except for *. 
4-F. using an Informal Method only

\begin{tabular}{|l|c|c|c|}
\hline \multirow{2}{*}{ Explanatory Variable } & \multicolumn{3}{|c|}{ Formal } \\
\cline { 2 - 4 } & $\begin{array}{c}\text { Estimate } \\
\text { (B) }\end{array}$ & S.E. & Odds Ratio \\
\hline Intercept & -1.440 & 0.036 & \\
\hline Age (reference category: 40+) & & & \\
\hline Age (1) <15 & -8.779 & 2.136 & 0.000 \\
\hline Age (2) 15-29 & $-0.039^{*}$ & 0.024 & 0.962 \\
\hline Age (3) 30-39 & -1.271 & 0.028 & 0.281 \\
\hline $\begin{array}{l}\text { Education (reference category: secondary } \\
\text { and above) }\end{array}$ & & & \\
\hline Educational Level: below secondary & $0.046^{* *}$ & 0.027 & 1.047 \\
\hline $\begin{array}{l}\text { Ever Worked Before (reference category: } \\
\text { never worked before) }\end{array}$ & 0.160 & 0.015 & 1.174 \\
\hline Wealth & -0.350 & 0.006 & 0.705 \\
\hline Household Size & -0.125 & 0.002 & 0.882 \\
\hline 1/dependency ratio & 1.268 & 0.025 & 3.553 \\
\hline Head (reference category: head) & & & \\
\hline Not Head & -2.057 & 0.016 & 0.128 \\
\hline $\begin{array}{l}\text { Region: Reference Category (Rural Upper } \\
\text { Egypt) }\end{array}$ & & & \\
\hline Region (1) - Greater Cairo & & & \\
\hline Region (2) - Alex and Suez Canal & $0.020^{*}$ & 0.014 & 1.020 \\
\hline Region (3) - Urban Lower Egypt & -0.671 & 0.019 & 0.511 \\
\hline Region (4) -Urban Upper Egypt & -0.667 & 0.015 & 0.513 \\
\hline Region (5) - Rural Lower Egypt & -6.963 & 0.282 & 0.001 \\
\hline Marriage (reference category: married) & -1.228 & 0.013 & 0.293 \\
\hline Not Married & & & \\
\hline Selection Term & 1.014 & 0.011 & 2.755 \\
\hline & 0.642 & 0.015 & 1.900 \\
\hline
\end{tabular}

- All Estimates are significant at the 1\% significance level, except for * .

- ** significant at $10 \%$ 
Table (5): Job Search Efficiency Index 1

(Probability of High Job Search Efficiency=1)

\begin{tabular}{|l|c|c|c|}
\hline \multirow{2}{*}{ Explanatory Variable } & \multicolumn{3}{|c|}{ Formal } \\
\cline { 2 - 4 } & $\begin{array}{c}\text { Estimate } \\
\text { (B) }\end{array}$ & S.E. & Odds Ratio \\
\hline Intercept & -2.570 & 0.024 & \\
\hline Age (reference category: 40+) & & & \\
\hline Age (1) <15 & -1.056 & 0.177 & 0.348 \\
\hline Age (2) 15-29 & 1.674 & 0.020 & 5.336 \\
\hline Age (3) 30-39 & 1.734 & 0.021 & 5.666 \\
\hline $\begin{array}{l}\text { Education (reference category: secondary } \\
\text { and above) }\end{array}$ & & & \\
\hline Educational Level: below secondary & -0.064 & 0.015 & 0.938 \\
\hline $\begin{array}{l}\text { Ever Worked Before (reference category: } \\
\text { never worked before) }\end{array}$ & 0.604 & 0.007 & 1.829 \\
\hline Wealth & 0.052 & 0.003 & 1.054 \\
\hline Household Size & -0.003 & 0.001 & 0.997 \\
\hline 1/dependency ratio & -1.337 & 0.013 & 0.263 \\
\hline Head (reference category: head) & & & \\
\hline Not Head & 0.620 & 0.010 & 1.859 \\
\hline $\begin{array}{l}\text { Region: Reference Category (Rural Upper } \\
\text { Egypt) }\end{array}$ & & & \\
\hline Region (1) - Greater Cairo & 0.636 & 0.008 & 1.889 \\
\hline Region (2) - Alex and Suez Canal & 2.223 & 0.010 & 9.239 \\
\hline Region (3) - Urban Lower Egypt & 1.418 & 0.007 & 4.131 \\
\hline Region (4) -Urban Upper Egypt & 0.124 & 0.008 & 1.132 \\
\hline Region (5) - Rural Lower Egypt & 0.860 & 0.006 & 2.364 \\
\hline Marriage (reference category: married) & & & \\
\hline Not Married & 0.155 & 0.005 & 1.168 \\
\hline Selection Term & -0.246 & 0.006 & 0.782 \\
\hline & & 725 & \\
\hline & & 149983.0 & \\
\hline & & $<.0001$ & \\
\hline
\end{tabular}

- All Estimates are significant at the 1\% significance level. 
Table (6): Internet Job Search

(Probability Modeled Using Internet Job Search=1)

\begin{tabular}{|l|c|c|c|}
\hline \multirow{2}{*}{ Explanatory Variable } & \multicolumn{3}{|c|}{ Formal } \\
\cline { 2 - 4 } & Estimate (B) & S.E. & Odds Ratio \\
\hline Intercept & -1.9287 & 0.024 & \\
\hline Age (reference category: 21-45) & & & \\
\hline Age (1) 1-20 & -6.995 & 0.639 & 0.001 \\
\hline $\begin{array}{l}\text { Education (reference category: secondary and } \\
\text { above) }\end{array}$ & & & \\
\hline Educational Level: below secondary & $-3.467^{* *}$ & 1.634 & 0.031 \\
\hline $\begin{array}{l}\text { Ever Worked Before (reference category: never } \\
\text { worked before) }\end{array}$ & -0.376 & 0.026 & 0.687 \\
\hline Wealth & 0.896 & 0.012 & 2.450 \\
\hline Residence (Reference Category: Rural) & & & \\
\hline Urban & 0.824 & 0.016 & 2.280 \\
\hline Selection Term & -2.118 & 0.020 & 0.120 \\
\hline
\end{tabular}

- All Estimates are significant at the $1 \%$ significance level.

- ** significant at the $5 \%$ significance level.

Table (7): Job Search Efficiency Index 2

(Probability of High Job Search Efficiency=1)

\begin{tabular}{|c|c|c|c|}
\hline \multirow{2}{*}{ Explanatory Variable } & \multicolumn{3}{|c|}{ Formal } \\
\hline & Estimate (B) & S.E. & Odds Ratio \\
\hline Intercept & -0.437 & 0.019 & \\
\hline \multicolumn{4}{|l|}{ Age (reference category: $40+$ ) } \\
\hline Age $(1)<15$ & -1.705 & 0.177 & 0.182 \\
\hline Age (2) 15-29 & 0.268 & 0.017 & 1.308 \\
\hline Age (3) 30-39 & 0.774 & 0.017 & 2.168 \\
\hline \multicolumn{4}{|l|}{$\begin{array}{l}\text { Education (reference category: secondary } \\
\text { and above) }\end{array}$} \\
\hline Educational Level: below secondary & -0.161 & 0.015 & 0.851 \\
\hline $\begin{array}{l}\text { Ever Worked Before (reference category: } \\
\text { never worked before) }\end{array}$ & 0.399 & 0.007 & 1.490 \\
\hline \multicolumn{4}{|l|}{$\begin{array}{l}\text { Region: Reference Category (Rural Upper } \\
\text { Egypt) }\end{array}$} \\
\hline Region (1) - Greater Cairo & 0.760 & 0.007 & 2.139 \\
\hline Region (2) - Alex and Suez Canal & 2.519 & 0.011 & 12.420 \\
\hline Region (3) - Urban Lower Egypt & 1.162 & 0.007 & 3.196 \\
\hline Region (4) -Urban Upper Egypt & 0.500 & 0.008 & 1.649 \\
\hline Region (5) - Rural Lower Egypt & 0.750 & 0.006 & 2.117 \\
\hline Selection Term & -0.563 & 0.006 & 0.570 \\
\hline $\begin{array}{c}\mathrm{N} \\
\text { Likelihood Ratio Chi-square } \\
\text { DF } \\
\text { Pr>Chi-square }\end{array}$ & & $\begin{array}{c}666 \\
122231.5 \\
11 \\
<0.0001\end{array}$ & \\
\hline
\end{tabular}

- All Estimates are significant at the $1 \%$ significance level. 

